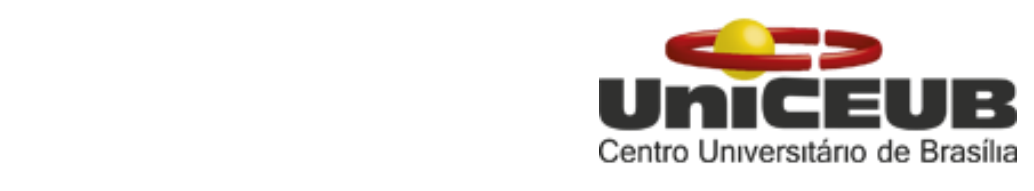

CENTRO UNIVERSITÁRIO DE BRASÍLIA - UniCEUB

FACULDADE DE TECNOLOGIA E CIÊNCIAS SOCIAIS APLICADAS FATECS

PROGRAMA DE INICIAÇÃO CIENTÍFICA

IGOR FRANCESCO FERREIRA DA SILVA

AVALIAÇÃO DO COMPORTAMENTO MECÂNICO DE UM SOLO DO DISTRITO FEDERAL COMPACTADO EM DIFERENTES UMIDADES PARA SER UTILIZADO NA CONFORMAÇÃO DE ATERROS RODOVIÁRIOS 


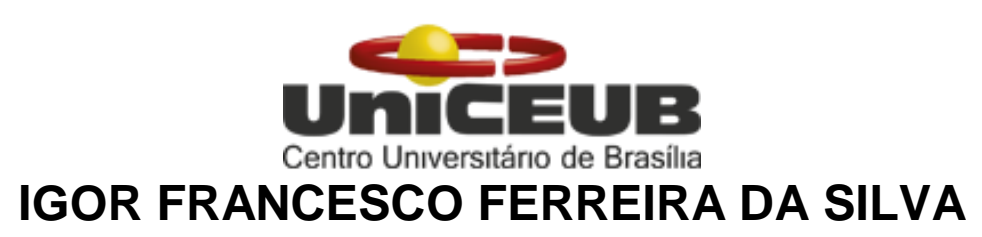

\section{AVALIAÇÃO DO COMPORTAMENTO MECÂNICO DE UM SOLO DO DISTRITO FEDERAL COMPACTADO EM DIFERENTES UMIDADES PARA SER UTILIZADO NA CONFORMAÇÃO DE ATERROS RODOVIÁRIOS}

\footnotetext{
Relatório final de pesquisa de Iniciação Científica apresentado à Assessoria de Pós-Graduação e Pesquisa pela Faculdade de Tecnologia e Ciências Sociais Aplicadas - FATECS

Orientação: Julián Asdrubal Buriticá García
}

\section{BRASÍLIA-DF}




\title{
AVALIAÇÃO DO COMPORTAMENTO MECÂNICO DE UM SOLO DO DISTRITO FEDERAL COMPACTADO EM DIFERENTES UMIDADES PARA SER UTILIZADO NA CONFORMAÇÃO DE ATERROS RODOVIÁRIOS
}

\author{
Igor Francesco Ferreira da Silva - UniCEUB, PIC Institucional, aluno bolsista \\ igor_francesco@hotmail.com
}

\author{
Julián Asdrubal Buriticá García - UniCEUB, professor orientador \\ julianburitica@gmail.com
}

O desenvolvimento econômico de um país se concentra nos eixos das grandes rodovias, que tem como objetivo direcionar todo o processo de transporte de insumos, produtos e serviços. No Brasil é notório o estado precário das estradas, muitos dos danos evidenciados, são provocados por movimentos de massa nos aterros rodoviários que podem ser originados por deficiências no processo de compactação. Para que um solo possa ser usado em obras de aterros rodoviários é necessário que se cumpram alguns requisitos, garantido que sejam alcançadas certas propriedades que melhoram seu comportamento mecânico. A presente pesquisa objetivou a obtenção de parâmetros de resistência para um material típico do Distrito Federal compactado com diferentes umidades para ser utilizado na conformação de aterros rodoviários. Para a execução do trabalho foi coletada uma amostra deformada de solo, retirada no campus do UniCEUB na Asa Norte. Depois de obter os parâmetros de resistência do solo, peso específico natural, ângulo de atrito e coesão, foram realizadas análises de estabilidade de taludes de aterros de diversas seções transversais hipotéticas, simuladas no módulo GeoSlope do programa GeoStudio, tendo como produto deste estudo os respectivos fatores de segurança de cada seção e suas características. O estudo comparativo dos fatores de segurança das seções para diferentes umidades do solo é de grande importância tendo em vista que o controle da umidade no canteiro de obras é precário, levando em consideração que o material dispõe-se a céu aberto e exposto a intempéries, tornando-se impraticável obter precisão e estabilidade no teor de umidade, sendo obrigado a trabalhar em valores diferentes da umidade ótima, ocasionando divergências entre projeto e execução. Após as análises realizadas, foi possível identificar que em alguns casos existe a possibilidade de se trabalhar em períodos de seca ou de pluviosidade elevada sem comprometer a construção, utilização e a segurança do aterro rodoviário. Observou-se que a Areia-argilosa do Distrito Federal além de possuir características ideais no ponto ótimo, também demonstrou cenários favoráveis no ramo mais seco da umidade, retornando elevados valores do fator de segurança. Em relação à inclinação dos aterros foi notável que quanto mais íngreme, o fator de segurança diminui, seguindo na mesma linha as seções com a altura mais elevada. Da mesma forma, quando aterros mais elevados possuíam banquetas em sua composição, os fatores de segurança se otimizavam numa tentativa de se aproximar às seções de menor altura, ratificando a finalidade da berma de equilíbrio.

Palavras-chave: Estabilidade de talude. Compactação. Aterro. 


\section{Sumário}

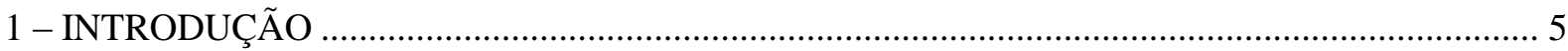

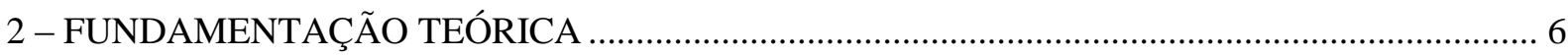

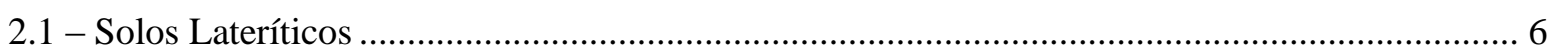

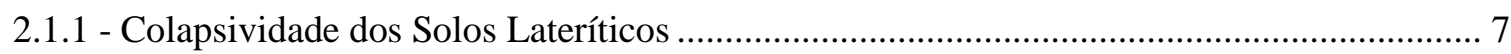

2.1.2 - Características Geotécnicas dos Solos Lateríticos do Distrito Federal ................................. 7

2.2 - Considerações normativas da compactação de aterros rodoviários ............................................ 10

2.2.1 - Considerações da teoria da compactação .......................................................................... 11

2.3 - Resistências ao cisalhamento para solos compactados com diferentes umidades .................... 12

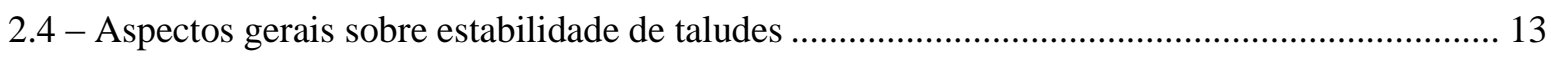

2.4.1 - Método de análise Morgenstern \& Price ........................................................................... 13

2.4.2 - Considerações sobre fator de segurança .......................................................................... 14

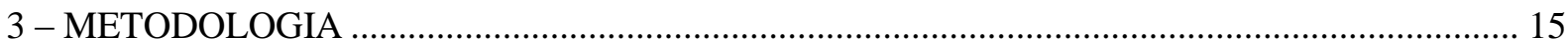

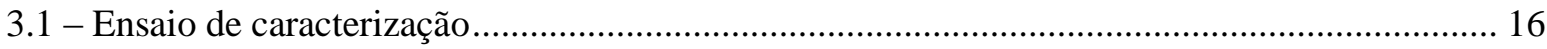

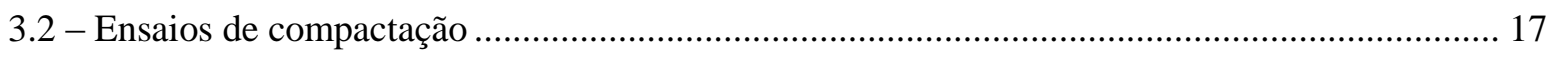

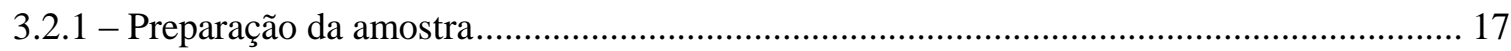

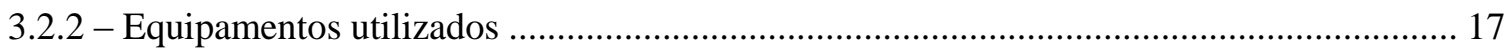

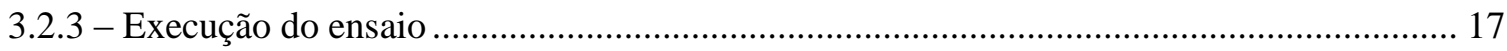

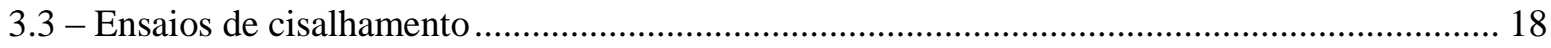

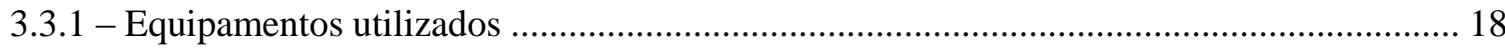

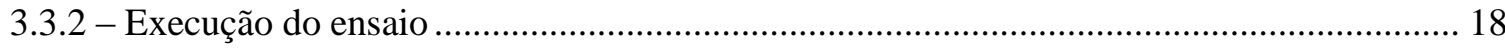

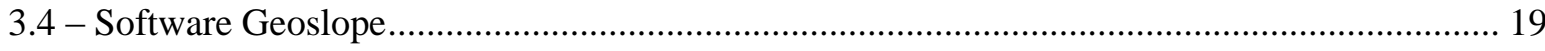

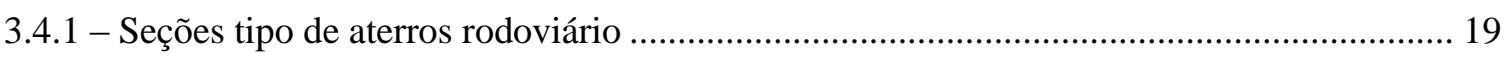

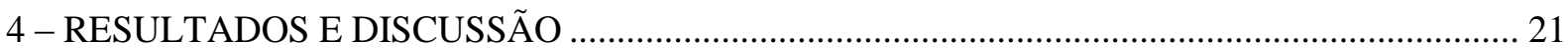

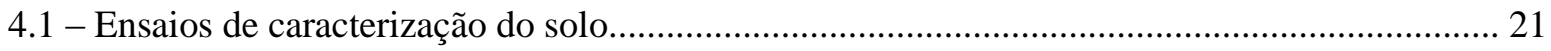

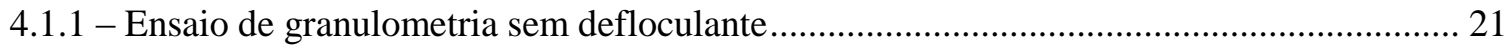

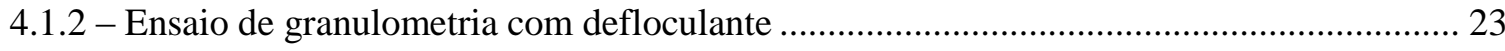

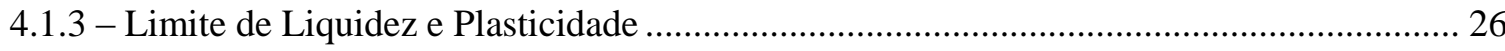

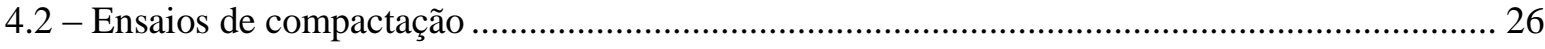

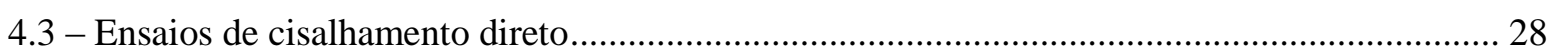

4.4 - Adaptações dos dados da campanha experimental .................................................................... 31

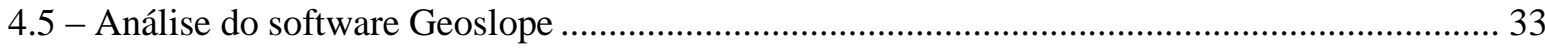

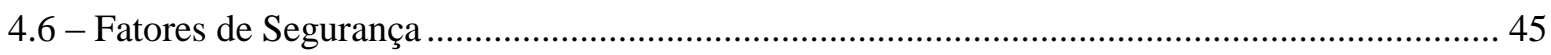

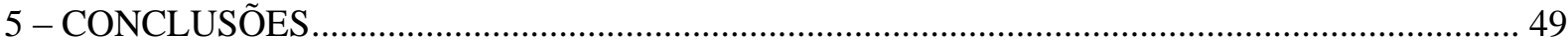

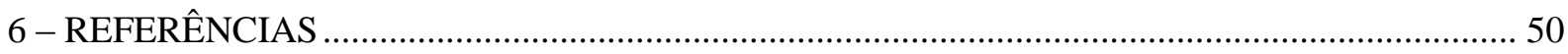




\section{1 - INTRODUÇÃO}

Os danos às rodovias causados por movimentos de massa em aterros são bem evidentes e geram grandes impactos no âmbito econômico e social. Este comprometimento é devido à extrema importância das estradas no desenvolvimento socioeconômico, tendo em vista que são utilizadas no funcionamento do comércio, promovendo a distribuição de produtos e serviços.

Neste contexto, é imprescindível ter maiores cuidados na conformação de aterros no processo de construção das estradas, conscientizando-se de que a maior causa de problemas ou manifestações patológicas surgidas na superfície ou até mesmo no interior do aterro, como trincamentos da estrutura do pavimento, recalques ou rupturas locais e globais, são causadas pela má execução, e não por má fiscalização de controle de veículos pesados.

Pela enorme importância que esta infraestrutura representa, e pela precária situação em que se encontra, é necessário aprofundar em estudos e pesquisas relacionadas ao assunto, desenvolver técnicas e produzir conteúdos que tornem a execução mais fácil e de maior qualidade promovendo melhores resultados e durabilidades de aterros construídos.

Como é extremamente forte a influência da umidade do material do corpo de aterro no projeto rodoviário e tendo uma dependência das propriedades geotécnicas como a compressibilidade, a resistência e a percolação em função do grau de compactação do material de empréstimo e da estrutura atingida, são de total importância promover o estudo da compactação em diferentes níveis de umidade tendo em vista que o solo se comporta de maneiras diferente na tensão e deformação devido a estar compactado no ramo úmido da curva ou no ramo seco.

Este trabalho visa estudar o comportamento mecânico de um solo do Distrito Federal compactado em diferentes umidades e sua aplicabilidade na construção de aterros rodoviários. O cumprimento deste objetivo dar-se-á pela obtenção de parâmetros de resistência reais advindos dos: ensaio de cisalhamento direto, caracterização física dos solos, dos parâmetros de resistência (ângulo de atrito e coesão) do solo compactado com variação de umidade e, após colher os resultados dos ensaios, pela realização de simulações numéricas de estabilidade de aterro usando diversas formas hipotéticas das seções transversais do material com diferentes alturas e inclinações.

De forma sucinta, a pesquisa teve como objetivo avaliar o potencial de aplicação de solos lateríticos do DF como materiais para construção de aterros rodoviários, considerando suas propriedades físicas e geotécnicas aproveitando que a composição do solo brasileiro é composta por este tipo de material. Definir através de ensaios de laboratório características e parâmetros de um determinado material e investigar seu funcionamento em diversas configurações para que seja possível submeter a análises em um software que retorne dados que permitam demonstrar o comportamento desse solo nos diversos estados de umidade e os respectivos fatores de segurança necessários para que os taludes fiquem estáveis. 


\section{2 - FUNDAMENTAÇÃO TEÓRICA}

\section{1 - Solos Lateríticos}

Devido às condições geológicas nas quais são formados os solos lateríticos, característico de regiões tropicais e de clima úmido, possuem propriedades peculiares e apresentam composição mineralógica diferenciada.

Surge então a necessidade de estudos sobre o comportamento peculiar dos solos lateríticos para diferentes fins e sobre metodologias apropriadas para avaliar a qualidade desses solos, já que boa parte do território brasileiro situa-se em zona de clima tropical.

Desde que compactados em condições específicas previamente determinadas, os solos lateríticos adquirem resistências altas e uma excelente capacidade de suporte, sendo capaz de apresentar pequena perda dessa capacidade quando imerso em água (GODOY, 1997 apud DELGADO, 2007).

São materiais criados a partir do processo intenso de intemperismo em solos residuais de zonas úmidas e tropicais, onde ocorrem elevadas temperaturas e precipitações abundantes que produzem a infiltração da água no solo carreando partículas finas e cátions básicos, sobrando no solo as partículas pesadas como alumínio e o ferro. Estas partículas formam vínculos cimentantes entre as partículas do solo, originando partículas de maiores diâmetros, denominadas lateritas (SANTOS, 2006; RESCHETTI JUNIOR, 2008).

$\mathrm{Na}$ Figura 1 e Figura 2 se pode observar a ocorrência dos solos lateríticos no mundo e no Brasil respectivamente.

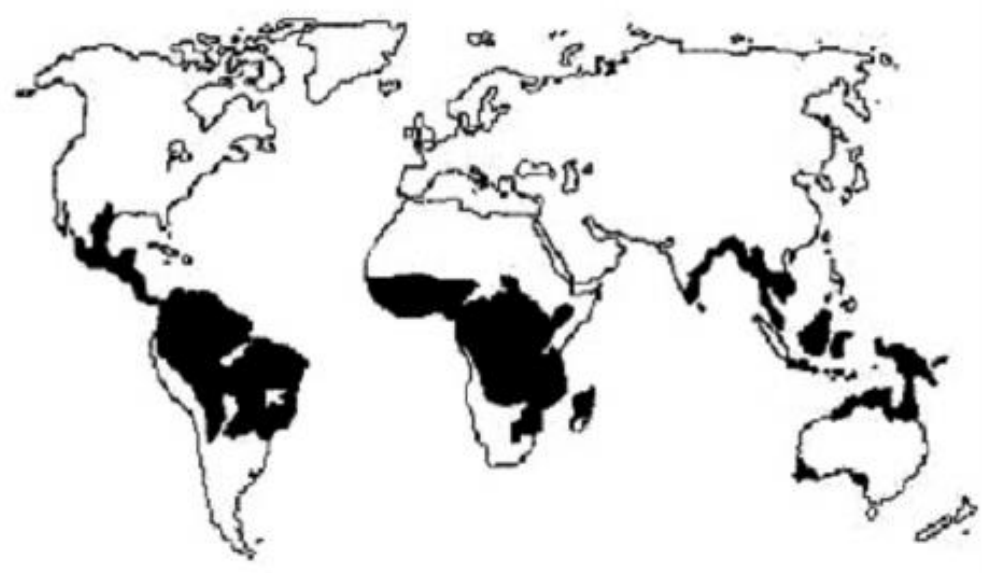

Solos Lateriticos

Figura 1 - Zonas que possuem solos lateríticos (Charman,1988 apud Bernucci, 1995).

Geralmente os solos lateríticos encontram-se não saturados na natureza, com elevado índice de vazios, e consequentemente pequena capacidade de suporte. Todavia, pode apresentar propriedades satisfatórias para emprego em diversas obras de engenharia a partir do processo de compactação. 


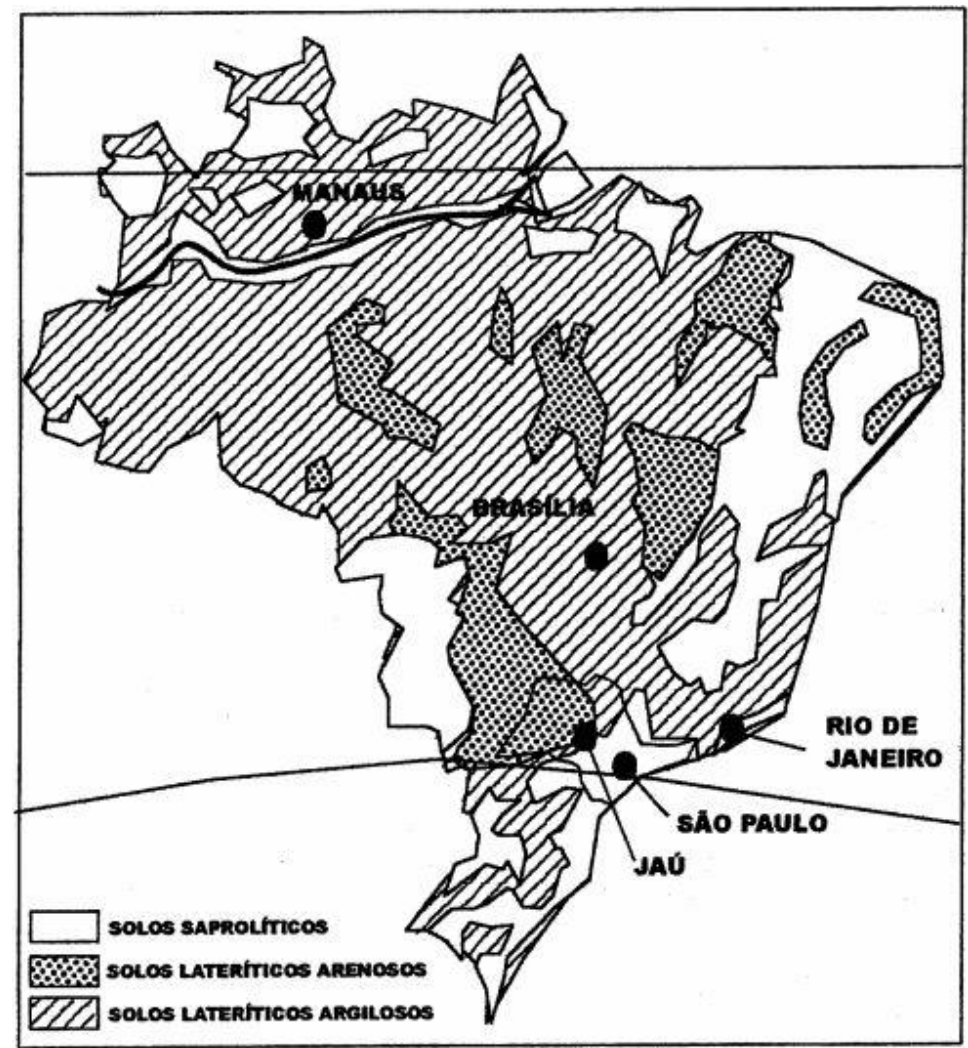

Figura 2 - Ocorrência de solos lateríticos no território brasileiro (NOGAMI et al, 2000)

\subsection{1 - Colapsividade dos Solos Lateríticos}

Segundo Mendonça (1990), a diminuição brusca do volume de um solo quando este sofre um aumento no seu teor de umidade e/ou aumento de tensões denominase colapso. A diminuição de volume é considerada brusca quando acontece numa velocidade superior à velocidade de adensamento de um solo argiloso saturado. A estrutura dos solos onde esse fenômeno acontece é macro-porosa metaestável, onde o esqueleto da estrutura forma-se por ligações temporárias entre os grãos de minerais do solo.

Estas ligações temporárias podem ser formadas por: pontes de argilas ou coloides, que possuem uma microestrutura onde se manifesta predominantemente forças de superfícies ou vínculos de propriedade cimentante, derivados da presença de cátions como $\mathrm{Na}, \mathrm{Mg}, \mathrm{Ca}$, Fe ou outros; óxidos de ferro, ou alumínio, situação tipicamente que ocorrem em solos lateríticos; ou tensões devido à presença de meniscos capilares nos solos (Nunez, 1975 apud Motta, 2006).

\subsection{2 - Características Geotécnicas dos Solos Lateríticos do Distrito Federal}

No Distrito Federal, por meio dos diversos processos ocorridos desde sua concepção, o solo possui propriedades, estruturas e comportamentos hidráulicos e mecânico peculiares (Guimarães et al., 1997). Os solos apresentam características próprias que foram herdadas a partir da resultante de fatores como rocha matriz, tempo, relevo clima e ação química e biológica acrescentando das ações humanas. 
A presença de agregações nos solos do Distrito Federal, segundo Camapum de Carvalho \& Leroueil (2000), faz com que a textura argilosa averiguada em ensaios granulométricos com o uso de defloculante não seja constada normalmente no solo em estado natural. Estas agregações são responsáveis pela geração de uma microestrutura importante para o comportamento e as propriedades dos solos, por se relacionarem com a presença de óxidos de ferro e alumínio (DELGADO, 2007).

A autora cita que Cardoso (1995) mostra a análise de um solo colapsível, coletado sob os taludes do Metrô de Brasília. A descrição da forma microscópica mostrou que uma parte considerável das frações argilosas encontravam-se sob a forma de agregados, e o índice de vazios era de 1. De modo parecido à "argila porosa", o solo possui uma quantidade importante de gibsita e alumínio em estado amorfo.

\subsection{3 - Caraterísticas das partículas e do comportamento da compactação}

Os fatores como a energia de compactação, o teor de umidade de compactação e o método de compactação empregado devem ser controlados, pelo motivo dos solos compactadoss em teores de umidades iniciais diferentes e/ou densidades diferentes apresentam comportamentos divergentes (Fredlund, 1997).

Por isto, as amostras de solo têm que ser preparadas e ensaiadas com grande cuidado em consequência da secagem prévia dos solos tropicais a partir de seu teor de umidade in situ pode modificar propriedades resultantes dos ensaios de caracterização e compactação.

Outro cuidado que se deve tomar é em relação à compactação que regularmente resulta numa progressiva quebra das partículas. Nesta situação, não se deve reutilizar solo em cada ponto da curva de compactação, pois o não atendimento deste procedimento acarretará numa situação onde as características de compactação do solo são modificadas gradualmente com o avanço do ensaio e, desta maneira, os resultados podem ser enganosos.

Tem sido evidenciado por diversos autores que o fenômeno de agregação de partículas é comum nos solos argilosos. Entretanto, por vezes não se consideram os aspectos relativos à porosimetria. Os micro e macro níveis da estrutura são presentes nos solos argilosos naturais e compactados. A macroestrutura que resulta de amostras preparadas com diferentes graus de compactação é diferente, apesar de sua mineralogia, textura e método de preparação igual. $\mathrm{O}$ comportamento de engenharia é determinado pelo arranjo estrutural junto com a mineralogia do solo como comentado por Queiroz de Carvalho \& Simmons (1997).

Os autores mostram que uma estrutura de grãos de areia pode possuir conectores de argila entre os grãos, ou contatos diretos, sem partículas de argila. Quando as partículas elementares estão dispostas homogeneamente, considera-se uma estrutura do tipo matricial com grãos de areia rodeados de partículas argilosas elementares gerando uma matriz. Ocasionalmente, as partículas elementares agrupam-se como se fossem um grão de maior tamanho. Neste caso, a micro estrutura é instituída por agregados.

Os solos compactados no ramo úmido da curva de compactação convergem à estrutura do tipo matricial. Em contrapartida, os solos compactados no ramo seco, ou que tendem ao colapso, habituam apresentar microestrutura de agregados ou com conectores de argila.

A constituição mineralógica das partículas influencia a sua componente de adsorção e a sua geometria interna, a sua componente capilar, no que se refere à 
sucção matricial. Desta forma um estado de tensões que incremente as tensões interpartículas é gerado, endurecendo a estrutura do solo e a deixando mais resistente. No caso de materiais com o mesmo índice de vazios, a distância das partículas tem uma maior variação nas estruturas floculadas que nas dispersas. Em consequência, no processo de secagem os primeiros possuem maior sucção capilar (Romo et al, 1979 apud Martínez, 2003).

Para os solos granulares, as partículas possuem formas arredondadas ou angulosas, cujo mineral quartzo é o principal constituinte, ocorrendo ainda à presença de mica e feldspato. As partículas arenosas podem ser chamadas de material inerte, onde predominam esforços de natureza gravitacional, formando um arranjo em que os grãos apoiam-se diretamente uns sobre os outros. A compactação desse solo se dá apenas por um processo de densificação do material.

Em relação aos solos argilosos compactados, diversas propriedades interferem na sua formação estrutural, como a composição mineralógica, as forças internas entre partículas, os esforços externos e o teor de umidade. Um dos fatores determinantes do tipo de estrutura é o teor de umidade empregado em conjunto com a energia de compactação. O teor de umidade influencia na criação de forças de repulsão responsável pela dupla camada iônica

$\mathrm{Na}$ mecânica dos solos clássica, existem dois tipos de estruturas proporcionados pelo teor de umidade de compactação: a estrutura floculada, quando o material é compactado no ramo seco da curva de compactação, e dispersa quando compactado no ramo úmido. Na estrutura dispersa, as duplas camadas difusas são formadas e os grãos tendem a se dispersar, formando uma orientação paralela entre si. Na estrutura floculada, as partículas ficam em contato face-aresta. Os solos com estrutura floculada mostram maior contração, maior condutividade hidráulica, maior resistência e maior expansividade quando submetidos a deformações pequenas de cisalhamento, que os solos de estrutura paralela dispersa (Jucá, 1990 e Martínez, 2003 apud Delgado, 2007). Tem-se uma estrutura intermediária entre estes dois tipos para solos compactados com energia Proctor Normal na umidade ótima.

Diversos fatores influenciam nos valores do limite de liquidez e do limite de plasticidade, geralmente tendo como principais fatores o teor de fração fina e a natureza mineralógica relata Queiroz de Carvalho (1987). É demonstrado pela literatura que os limites de plasticidade e liquidez aumentam a partir do momento em que os teores de argila do solo se elevam independentemente da origem do solo, mesmo sendo de região tropical ou temperada. Uma vez que a variação está intimamente relacionada aos minerais constituintes e ao nível de intemperismo sofrido pelo solo, espera-se que este varie com o teor de argila existente no material.

Para entender o comportamento dos solos na engenharia prática é importante estudar a estrutura do solo (Mitchel, 1956; Lambe, 1958; Holtz and Kovacs, 1981 apud Buriticá, 2013). Segundo Buriticá "O estudo da estrutura do solo pode ser estudado usando microscópios óticos e eletrônicos".

O autor explana e em sua pesquisa (2013, p. 12) que:

Segundo Cetin et al.(2007) analisaram a microestrutura de corpos de prova de argila natural misturada com muscovita e mica, compactados pelo método proctor normal e mediram a orientação de 65.594 elementos tirados da base, centro e topo do corpo de prova compactado e concluíram que o padrão da orientação das partículas de um solo compactado no ramo seco é aproximadamente aleatória, e apresenta um ângulo meio de $43^{\circ} \mathrm{com}$ a horizontal, só $13,2 \%$ das partículas mostraram uma orientação entre 0 e $10^{\circ}$, a porosidade é grande e os poros são geralmente interconectados. Quando a umidade aumenta ao aproximar-se da umidade ótima, a orientação preferencial aumenta também, a porcentagem de partículas orientadas entre 
0 e $10^{\circ}$ aumenta a $20,4 \%$. Depois deste ponto a porcentagem de partículas orientadas entre 0 e $10^{\circ}$ começa a diminuir até o valor de $5,3 \%$, indicando que o aumento da umidade geralmente não gera uma orientação preferencial, também concluíram que o grau de orientação de partículas é maior na base do corpo de prova compactado.

\section{2 - Considerações normativas da compactação de aterros rodoviários}

Segundo a Norma DNIT 108/2009 - ES - Terraplenagem - Aterros Especificação de serviço, os aterros são segmentos de rodovia cuja implantação requer depósito de materiais provenientes de cortes e/ou de empréstimos no interior dos limites das seções de projeto (Off sets) que definem o corpo estradal. O corpo de aterro é a parte do aterro situada sobre o terreno natural até 0,60 metros abaixo da cota correspondente ao greide de terraplenagem.

Destinada a diminuir o volume de vazios de um solo, a compactação é a operação por processo manual ou mecânico e é utilizada com o objetivo de aumentar a massa específica, estabilidade e resistência.

Segundo Ricardo (2007), as especificações gerais de terraplenagem do DNER estabelecem que os aterros deverão ser compactados até $60 \mathrm{~cm}$ abaixo do greide, atingindo a massa específica aparente seca correspondente a $95 \%$ da massa específica obtida no ensaio DNER-DPT-M 47-64. Os últimos $60 \mathrm{~cm}$ do aterro, que servirão de subleito para o pavimento, serão compactados até atingir $100 \%$ da massa específica obtida no ensaio mencionado.

A umidade do material deverá ser a umidade ótima determinada naquele ensaio, com a variação de $+/-3 \%$, e a espessura das camadas já adensadas de 20 a $30 \mathrm{~cm}$.

Quanto a qualidade dos materiais, a norma determina que deverão ser evitados, na execução do aterro, solos com índice de suporte de Califórnia menor que 2 (CBR <2) e com expansão maior do que $4 \%$.

São frequentes também, as especificações que se referem ao grau de compactação em relação aos ensaios do Proctor Normal (Norma AASHTO T-99-57), e ao Proctor modificado (Norma AASHTO T-180-57), e estabelecendo-se os valores de G 95 ou $100 \%$ da massa específica máxima obtida naqueles ensaios. (Ricardo, 2007)

A última especificação do DNIT, Norma DNIT 108/2009 - ES - Terraplenagem - aterros - Especificações de serviço, apresenta uma diferença com respeito às normas DNER anteriores e é a exigência de compactação de aterros na umidade ótima $+/-3 \%$ até se obter a massa específica aparente seca correspondente a $100 \%$ da massa específica aparente máxima seca do ensaio realizado pela norma DNERME 129/94, Método A (Proctor normal).

Para as camadas finais, aquela massa específica aparente seca deve corresponder a $100 \%$ da massa específica aparente máxima seca do ensaio DNER-ME 129/94, método $B$.

Em todas as especificações se apresentam as exigências de que os trechos que não atingirem as condições mínimas de compactação devem ser escarificados, homogeneizados, levados à umidade adequada e novamente compactados de acordo com o estabelecido no projeto de engenharia. 


\subsection{1 - Considerações da teoria da compactação}

Segundo Fernandes (1994) a compactação é entendida pelo processo pelo qual uma massa de solo constituída por grãos rodeados de água e ar nos seus espaços vazios entre partículas tem seu volume reduzido pela diminuição destes vazios em consequência da aplicação repetida de cargas. Este procedimento permite um aumento na resistência de cisalhamento e reduz a deformabilidade e a permeabilidade do material.

No passado, a técnica de compactação era realizada de maneira totalmente empírica e sem nenhum tipo de fundamento técnico. A partir de meados dos anos 30, Proctor teve o propósito de aprimorar a técnica de compactação, com os primeiros estudos e trabalhos sobre o processo de compactação de aterros. Esta iniciativa permitiu grandes desenvolvimentos nessas técnicas de compactação. Proctor criou um ensaio dinâmico para determinar de forma experimental a curva de compactação (Ribeiro, 2008).

De acordo com (Buriticá, 2013) Além de Proctor outros cientistas realizam pesquisas no século passado. Stanton em 1927 pesquisou o efeito da umidade de compactação e em seguida, no ano de 1933, Proctor expôs conceitos sobre peso específico máximo e umidade ótima. No ano de 1948, foram apresentador diversos artigos discursando sobre compactação em campo e em laboratório e sobre experiências empíricas de compactação em construções de barragens e rodovias. A ocasião em que foram apresentadas essas pesquisas no ano de 1948 foi na conferência internacional de mecânica dos solos e engenharia de fundações.

Os solos compactados se comportam mecanicamente, de acordo com Buriticá, em função do grau de saturação, do índice de vazios e da estrutura do solo que é diretamente dependente da forma com que se compacta o material. Essa compactação pode reduzir características do material como a expansão e a retração, aumentar o fator de segurança e aumentar a capacidade de suporte do solo (Das, 1990).

Na compactação, a água diminui a resistência ás deformações angulares entre os grãos do material, propiciando o seu deslocamento relativo. Como o processo é dado pela diminuição do volume, os vazios são diminuídos até que haja a impossibilidade de 0 ar que sobrou escape. A partir desse momento alcançasse o ponto de maior eficiência da compactação e qualquer aumento de água tenderá a aumentar os espações entre os grãos reduzindo a densidade seca das partículas. A energia aplicada no material é totalmente utilizada para a redução do volume ou para induzir deformações angulares à armação do solo. Ao deparar-se com a densidade máxima do material, qualquer acréscimo de compactação servirá apenas para regularizar o solo deixando sua estrutura mais alinhada (Buriticá, 2013).

Segundo Ribeiro (2008) Lambe e Whitman apresentaram uma teoria em que apresenta as mudanças na concentração eletrolítica das partículas em relação à compactação do solo. Concluiu-se que quanto maior a energia, maior será o grau de dispersão dos grãos para o mesmo teor de umidade. A repulsão das partículas cresce de acordo com o aumento da umidade, o que possibilita uma melhor organização entre as partículas para uma determinada quantidade de energia. Então observou-se que, as partículas tendem a organizar-se de forma mais paralelas entre si ao aumentar a quantidade de energia de compactação. De acordo com (Lambe e Whitman, 1979 apud Buriticá, 2013) isto acontece pelo fato de não ter mais a expulsão do ar dos vazios do solo pelo motivo do material ter alcançado a densidade máxima e as 
amostras tendem a permanecer com o grau de saturação aproximadamente constante.

No caso das areias puras que são solos que não apresentam coesão, nota-se que o teor de umidade de compactação influencia de forma menos marcante na resistência ao cisalhamento. Independente de o solo ter sido compactado no ramo úmido ou seco, a saturação não acarreta uma diminuição sensível na resistência (FERNANDES, 1994).

\section{3 - Resistências ao cisalhamento para solos compactados com diferentes umidades}

A resistência ao cisalhamento de um solo depende da tensão normal efetiva aplicada no plano de cisalhamento e do grau de orientação das partículas. A tensão normal efetiva é função da poropressão, sendo a poropressão função do índice de vazios, do grau de orientação e da estrutura do solo (Pinto, 2000). Para mostrar o comportamento de solos compactados Lambe e Whitman (1979) referenciam ensaios realizados por Seed e Chan (1959) que mostram a influência da umidade de compactação no comportamento tensão-deformação em amostras de caulim.

A máxima tensão de cisalhamento que um solo pode resistir antes da ruptura, ou num plano em que estiver ocorrendo à ruptura é como pode ser definida a resistência ao cisalhamento de um solo. Este ocorre devido ao deslizamento entre corpos sólidos ou entre partículas do solo. O atrito e a coesão são os principais fenômenos que influem na resistência ao cisalhamento (Pinto, 2000).

A resistência por atrito é a força tangencial necessário para ocorrer o deslizamento entre dois planos. O ângulo de atrito é o ângulo formado entre a força resultante das forças atuantes (tangencial e normal) e a força normal antes que haja deslizamento. A parcela de resistência devida à atração química entre partículas, e independente da força normal é chamada de coesão real. Esta parcela está presente principalmente em solos finos argilosos e siltosos e em solos granulares com presença de cimentantes.

A coesão aparente se apresenta em solos finos não saturados pela pressão capilar de água que gera uma resistência que desaparece com a saturação do solo.

A resistência ao cisalhamento de um solo depende da tensão normal efetiva aplicada no plano de cisalhamento e do grau de orientação das partículas. A tensão normal efetiva é função da poro-pressão, sendo esta a função do índice de vazios, do grau de orientação e da estrutura do solo (Pinto, 2000). Para mostrar o comportamento de solos compactados Lambe \& Whitman (1979) referenciam ensaios realizados por Seed \& Chan (1959) que mostram a influência da umidade de compactação no comportamento tensão-deformação em amostras de caulim.

Os solos compactados no ramo seco, quando comparados com o ramo úmido, demonstram maiores resistências de pico. E ainda, o colapso é do tipo plástico para úmido e do tipo frágil para o seco. Esse comportamento dá-se na desigualdade entre as estruturas dos solos depois da compactação e em consequência, nas poropressões que se desenvolvem nos ensaios triaxiais que são maiores no ramo úmido, e certos solos podem apresentar estrutura colapsível quando compactados num ramo bastante seco (Massad, 2010). 


\section{4 - Aspectos gerais sobre estabilidade de taludes}

$\mathrm{Na}$ prática comum de órgãos públicos, infelizmente, são desprezadas as análises de estabilidades de aterros rodoviários, sendo estas de grande importância. Nas normas e especificações técnicas apresentam-se taludes padrão de corte e aterro que não consideram os condicionantes particulares de cada caso como é o tipo de material, altura de aterro, grau de compactação, etc.

Os fatores de segurança obtidos pelos cálculos de estabilidade são de extrema importância para determinar o nível de risco e/ou segurança que cada projeto em particular deve ter segundo a importância da rodovia.

Atualmente um os métodos mais utilizados consideram uma superfície de ruptura não circular e satisfaz todas as exigências de equilíbrio de forças verticais, equilíbrio de forças horizontais, equilíbrio estático e equilíbrio de momentos. Este é o método de Morgenstern \& Price (1965) que resolve o equilíbrio geral do sistema e é mais vantajoso em relação a ter considerações mais precisas que no método de Fellenius, Jambu, Bishop ou outros métodos considerados como não exatos.

\subsection{1 - Método de análise Morgenstern \& Price}

Como é descrito no livro Obras de Terras, de Massad, que diz que o método de Morgenstern \& Price é uma variação do método sueco assim como os métodos de Fellenius e Bishop simplificado que são advindos dos métodos de equilíbrio-limite que parte do pressuposto que o solo comporta-se como material rígido-plástico e, sem se deformar, rompe-se bruscamente.

Não se justifica consumir muito tempo em análises detalhadas para projetos preliminares classificados como risco desprezível. Para estes, recomenda-se o uso de métodos convencionais e simplificados com superfícies circulares de ruptura como Bishop simplificado. Entrementes, para projetos considerados como risco pequeno e médio, é recomendável o uso de métodos simplificados com superfícies de ruptura não circulares como Jambu, ou métodos rigorosos como Morgenstern \& Price que, alinhados a estudos geológicos e geotécnicos mais detalhados torna-se capaz de analisar projetos de risco elevado. Desta feita, este é o método de análise adotado para a presente pesquisa.

As seguintes hipóteses são assumidas na formulação dos métodos de equilíbrio limite como o método de Morgenstern \& Price:

- A definição a priori de uma superfície de deslizamento;

- O solo se comporta segundo um modelo rígido perfeitamente plástico do tipo Mohr Coulumb;

- O fator de segurança dos componentes coesivos e de atrito da resistência ao cisalhamento é igual para todos os solos envolvidos;

- O fator de segurança é o mesmo para todas as fatias.

Neste método para resolver a indeterminação do problema, admite-se uma relação entre as forças horizontais $\mathrm{E}$ e $\mathrm{T}$ da seguinte forma:

$$
T=\lambda \cdot f(x) \cdot E
$$

Onde, 
$\lambda$ : Constante a ser determinada por processo iterativo $f(x)$ : função que precisa ser especificada, neste caso a análise será realizada com uma função do tipo half-sine.

Todas as condições de equilíbrio de forças e de momentos são satisfeitas ao mesmo tempo pelas condições de estabilidade. A massa potencialmente instável é repartida em fatias infinitesimais e para ser aplicado necessita-se da ajuda de um computador para os cálculos.

\subsection{2 - Considerações sobre fator de segurança}

Segundo o livro Fundamentos de engenharia geotécnica (Das, 2007) o fator de segurança deve ser determinado pelo engenheiro encarregado da análise de estabilidade do talude e que geralmente é definido por:

$$
F_{s}=\frac{\tau_{f}}{\tau_{d}}
$$

Onde $F_{S}=$ fator de segurança em relação à resistência;

$\tau_{f}=$ resistência média ao cisalhamento do solo;

$\tau_{d}=$ resistência média ao cisalhamento desenvolvido ao longo da superfície potencial de ruptura.

Quando $F_{s}$ é igual a 1, o talude está em um estado de ruptura iminente e um valor maior que 1 para o fator de segurança em relação à resistência é aceitável para um projeto estável de talude. Já se o fator for inferior a 1 a construção é instável.

A definição do valor admissível para o fator de segurança vai depender, entre outros fatores, das consequências de uma eventual ruptura, em termo de perdas humanas, econômicas e ambientais. Devem ser consideradas as situações atuais e futuras, previstas ao longo da vida útil do talude estudado (ABNT 11682/09).

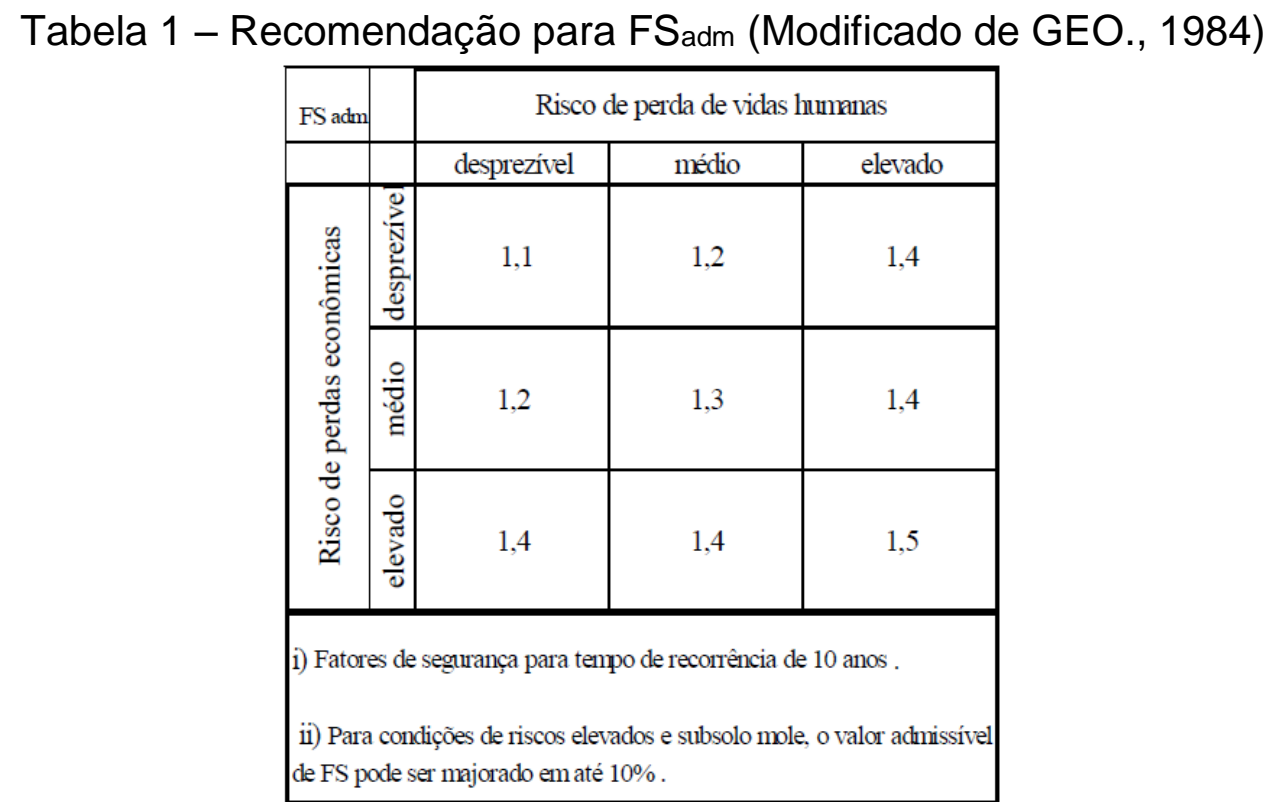


Tabela 2 - Fatores de segurança mínimos para deslizamentos (ABNT $11682 / 09)$.

\begin{tabular}{|c|c|c|c|}
\hline $\begin{array}{l}\text { Nivel de segurança contra } \\
\begin{array}{r}\text { danos a vidas } \\
\text { humanas }\end{array} \\
\text { segurança contra } \\
\text { danos materiais e ambientais }\end{array}$ & Alto & Médio & Baixo \\
\hline Alto & 1,5 & 1,5 & 1,4 \\
\hline Médio & 1,5 & 1,4 & 1,3 \\
\hline Baixo & 1,4 & 1,3 & 1.2 \\
\hline \multirow{2}{*}{\multicolumn{4}{|c|}{ 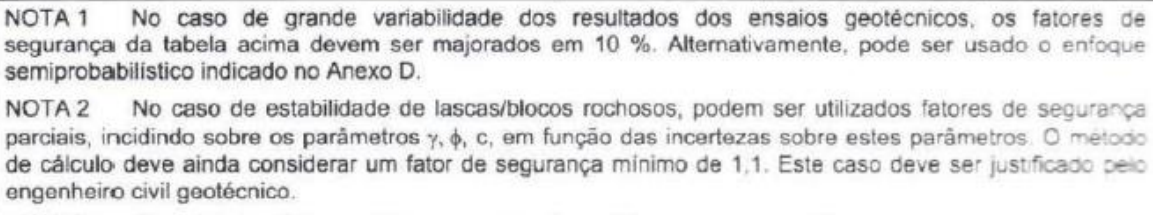 }} \\
\hline & & & \\
\hline \multicolumn{4}{|c|}{ Esta tabela nảo se aplica aos casos de rastejo, voçorocas, ravinas e queda ou rolamento se } \\
\hline
\end{tabular}

Tabela 3 - FS recomendados para remediação de escorregamento existentes (GEO., 1984)

\begin{tabular}{|c|c|c|}
\hline \multicolumn{3}{|c|}{ Risco de perda de vidas humanas } \\
\hline desprezivel & médio & elevado \\
\hline FS $>1,1$ & FS $>1,2$ & FS $>1,3$ \\
\hline Obs.: Fatores de segurança para periodo de \\
recorrência de 10 anos.
\end{tabular}

\section{3 - METODOLOGIA}

A metodologia da pesquisa consiste na realização de ensaios de laboratório com corpos de prova compactados planejando avaliar a estabilidade de talude compactados em umidade ótima, umidade ótima $-2 \%$, umidade ótima $-4 \%$, umidade ótima $+2 \%$ e umidade ótima $+4 \%$.

O solo foi coletado no Distrito Federal, com característica Areia-argilosa. As amostras foram retiradas de um poço de aproximadamente 1 metro de profundidade e 1 metro de diâmetro na situação deformada para serem investigadas suas propriedades quando compactadas.

O trabalho iniciou-se com a coleta do solo nas proximidades da instituição de ensino UniCEUB e com a revisão teórica de conceitos de solos tropicais lateríticos, revisão das normas dos ensaios a serem realizados e consultas em trabalhos já realizados semelhantes ao tema proposto. Em seguida foram promovidos os ensaios de laboratório. Os ensaios geotécnicos foram divididos em ensaios de caracterização, de compactação, e de cisalhamento, todos realizados a partir das amostras deformadas coletadas, com a finalidade de classificar o solo e conhecer suas propriedades conforme prescrições da NBR 6457 e NBR 7182 (ABNT, 1986). 
Foram realizados ensaios de caracterização para determinação das propriedades do solo como umidade natural e higroscópica, peso específico real dos grãos, peso específico natural, limite de liquidez, limite de plasticidade e índice de plasticidade. Com o objetivo de determinar a umidade ótima e o peso específico máximo foi obtida a curva de compactação por meio da realização de ensaios de compactação com energia Proctor Normal e com a finalidade de obter a resistência de cisalhamento do solo foram realizados ensaios de cisalhamento direto tipo $\mathrm{CU}$ (adensado não drenado).

Os resultados da fase experimental foram utilizadas em simulações numéricas de estabilidade de taludes em seções típicas hipotéticas de aterros rodoviários com diferentes inclinações e diferentes alturas. As seções foram definidos em aterros de 5 metros de altura com inclinações de 1:1, 1:2, 1:4 e 3:2, e de 10 metros para as mesmas inclinações com e sem adição de banquetas de 4 metros de largura.

\section{1 - Ensaio de caracterização}

Os ensaios de caracterização foram embasados nas seguintes normas para determinação do peso específico natural do solo, massa específica dos grãos, granulometria e limites de consistência:

- NBR 6457/86 - Amostra do solo - Preparação para ensaio de compactação e ensaios de caracterização;

- NBR 6508/84 - Densidade real dos grãos;

- NBR 7181/84 - Solo - Análise granulométrica.

- NBR 6459/84 - Solo - Limite de liquidez;

- NBR 7180/84 - Solo - Limite de plasticidade;

Sabendo-se que a argila comporta-se de maneira diferente relativo ao grau de umidade, é possível basear-se nisto para determinar os limites de consistência do solo. A argila se comporta como líquida quando o teor de umidade é alto e a medida que vai perdendo umidade se torna plástica, entretanto quanto mais seco estiver mais quebradiça se torna.

A determinação do limite de liquidez é dada pelo teor de umidade do solo compatível com o fechamento de uma ranhura feita nele e golpeada 25 vezes no aparelho de Casagrande. Com o valor obtido do número de golpes necessário para fechar a ranhura da amostra e as umidades correspondentes, traça-se a linha de escoamento do solo de 5 pontos numa escala semilogaritmica.

O limite de plasticidade é descoberto com a modelagem de pequenos cilindros de $3 \mathrm{~mm}$ de diâmetro e $10 \mathrm{~cm}$ de comprimento com o mínimo de umidade possível, formando os rolos com a palma da mão tentando impedir que eles se quebrem.

Com o valor do limite de liquidez e do limite de plasticidade descobre-se o índice de plasticidade pela fórmula:

Onde:

$$
I P=W L-W p
$$

IP - Índice de Plasticidade

$W L$ - Limite de Liquidez

Wp - Limite de Plasticidade 
O índice de plasticidade estabelece em que parte o solo se encontra em estado plástico fornecendo critérios para isso, considerando ser máximo para argilas e nulo para as areias. Isto é, quanto maior o índice de plasticidade, maior será o teor de argila e mais plástico será o material.

\section{2 - Ensaios de compactação}

Foram realizados ensaios de compactação com energia Proctor Normal com a finalidade de achar a curva de compactação (massa específica aparente seca versus teor de umidade). O ensaio normatizado pela AASHO (American Association of State Highway Officials) foi desenvolvido por Proctor e é conhecido como AASHO Standard ou como Proctor Normal que no Brasil foi normatizado pela ABNT NBR 7182/86

\subsection{1 - Preparação da amostra}

Foram peneiradas e destorroadas $45 \mathrm{~kg}$ de amostra de solo em umidade higroscópica até passarem completamente na peneira $4.8 \mathrm{~mm}$, e ensacadas em 6 sacos de $4500 \mathrm{~g}$.

\subsection{2 - Equipamentos utilizados}

Foram utilizados no ensaio de compactação os seguintes equipamentos conforme descrito na norma NBR 7182:1988:

- Balanças capazes de pesar $10 \mathrm{~kg}$ e $200 \mathrm{~g}$, com resoluções de $1 \mathrm{~g}$ e $0,01 \mathrm{~g}$, respectivamente.

- Peneiras de 19 e $4.8 \mathrm{~mm}$

- Estufa

- Cápsulas metálicas

- Bandejas metálicas

- Régua de aço biselada

- Espátulas

- Cilindro metálico grande (Cilindro de CBR)

- Colarinho

- Molde cilíndrico

- Disco espaçador

- Base

- Soquete grande

- Provetas de vidro com capacidade de 1000, 200 e $100 \mathrm{~cm}^{3}$

- Extrator de corpo de prova

- Papel filtro

\subsection{3 - Execução do ensaio}

Após preparação das amostras, separaram-se 5 cilindros de CBR e procedeuse a compactação. 
Em cada cilindro foi utilizada uma amostra com umidade diferente, variando de $18 \%$ a $26 \%$, com acréscimo de $2 \%$ por cilindro, para a determinação dos 5 pontos da curva de compactação.

A energia utilizada no ensaio foi a Proctor Normal, ou seja, 5 camadas de 12 golpes e aproximadamente $3 \mathrm{~cm}$ cada.

Umidades de compactação para retirada de amostras para o cisalhamento direto:

- Umidade ótima

- Umidade ótima - $2 \%$

- Umidade ótima $+2 \%$

- Umidade ótima $-4 \%$

- Umidade ótima $+4 \%$

\section{3 - Ensaios de cisalhamento direto}

A realização do ensaio de cisalhamento foi necessária para encontrar as características do solo no que se refere à resistência ao cisalhamento, ângulo de atrito e coesão das partículas do solo a fim de utilizar estes dados na simulação da seção de aterro hipotética no software Slope/W.

\subsection{1 - Equipamentos utilizados}

Equipamentos utilizados no ensaio de cisalhamento direto, conforme descrito na norma ASTM D3080:2011:

- Caixa bipartida dotada de placas dentadas e perfuradas;

- Pedras porosas de topo e base;

- Cap para transmissão de carga;

- Molde do corpo de prova;

- Prensa equipada com motor e sistema de transmissão de carga;

- Extensômetros;

- Célula de carga.

\subsection{2 - Execução do ensaio}

A amostra foi compactada no laboratório com as umidades de compactação da pesquisa e levada ao equipamento de cisalhamento direto.

Antes de submeter à amostra ao sistema de aplicação de carga, determinaramse as dimensões do corpo de prova (altura, lado e área).

Também foram pesadas três cápsulas numeradas, e nelas foram colocadas porções da amostra de solo, a fim de proceder o cálculo de umidade. As cápsulas foram pesadas com a amostra em umidade natural e, em seguida, higroscópica.

O corpo de prova da amostra foi moldado com o auxílio do molde e de um estilete a partir da amostra compactada. O molde foi colocado na caixa bipartida e ajustado à prensa de cisalhamento. Após a montagem da caixa, instalaram-se também os extensômetros vertical e horizontal. 
$\mathrm{Na}$ prensa de cisalhamento, o corpo de prova recebeu cargas verticais, que geraram um adensamento, e em seguida, cargas horizontais, que provocaram o cisalhamento.

Iniciou-se com uma carga vertical com magnitude de $50 \mathrm{kPa}$, fazendo-se as leituras no extensômetro de forma automática e computadorizada com velocidade de $0,038 \mathrm{~mm} / \mathrm{min}$. Ao termino disto foram repetidos os procedimentos com cargas de $100 \mathrm{Kpa}$ e $200 \mathrm{Kpa}$ respectivamente para enfim concluir uma envoltória.

O ensaio baseia-se no critério de Mohr-Coulomb e tem como objetivo obter valores de ângulo de atrito interno do solo e do intercepto coesivo.

O equipamento utilizado na pesquisa se mostra na Figura 3.

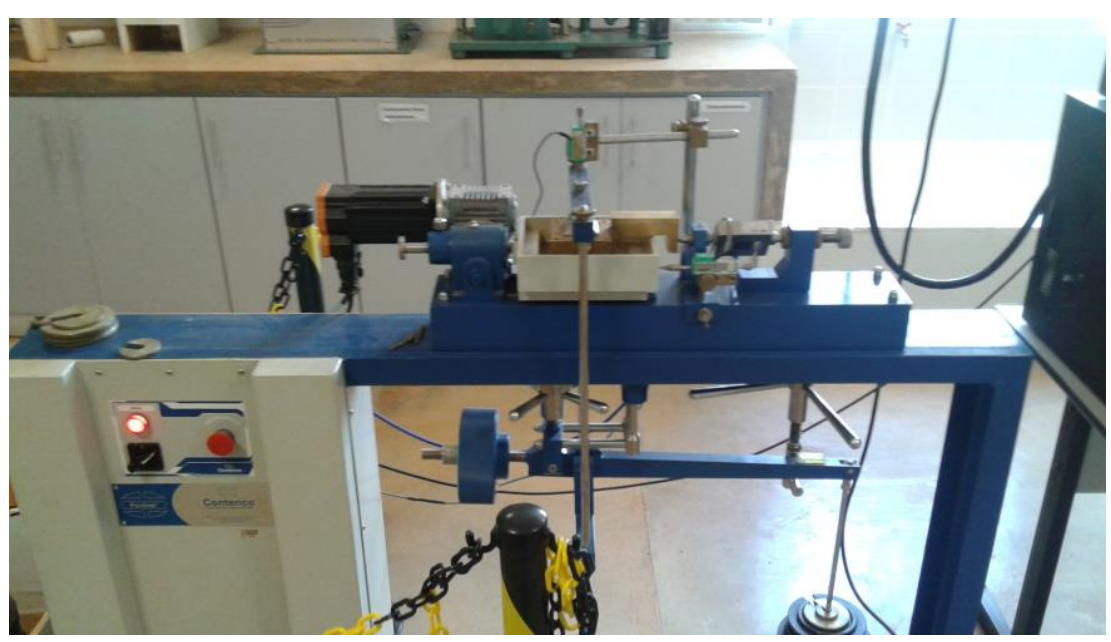

Figura 3 - Aparelho usado no Ensaio de Cisalhamento Direto Laboratório de Geotecnia do UniCEUB

\section{4 - Software Geoslope}

Foram utilizados os parâmetros obtidos na fase experimental para simular e analisar o comportamento de seções hipotéticas de aterro rodoviário. As análises foram feitas utilizando o software GeoStudio da Geoslope International Ltda. O software é compatível com o ambiente Microsoft Windows e possui uma interface bem amistosa.

O Slope $M$ utiliza o método dos elementos finitos para o cálculo de deformações e para análise de estabilidade de talude. O Método dos elementos finitos constitui-se na divisão do domínio do problema em subdomínios ou elementos, formulando o comportamento em função de sua geometria e propriedades, conectadas apenas em alguns pontos (nós), através dos quais interagem entre si (Buritica, 2013).

\subsection{1 - Seções tipo de aterros rodoviário}

As seções transversais analisadas na pesquisa se apresentam a seguir nas Figuras 4,5 e 6 . 

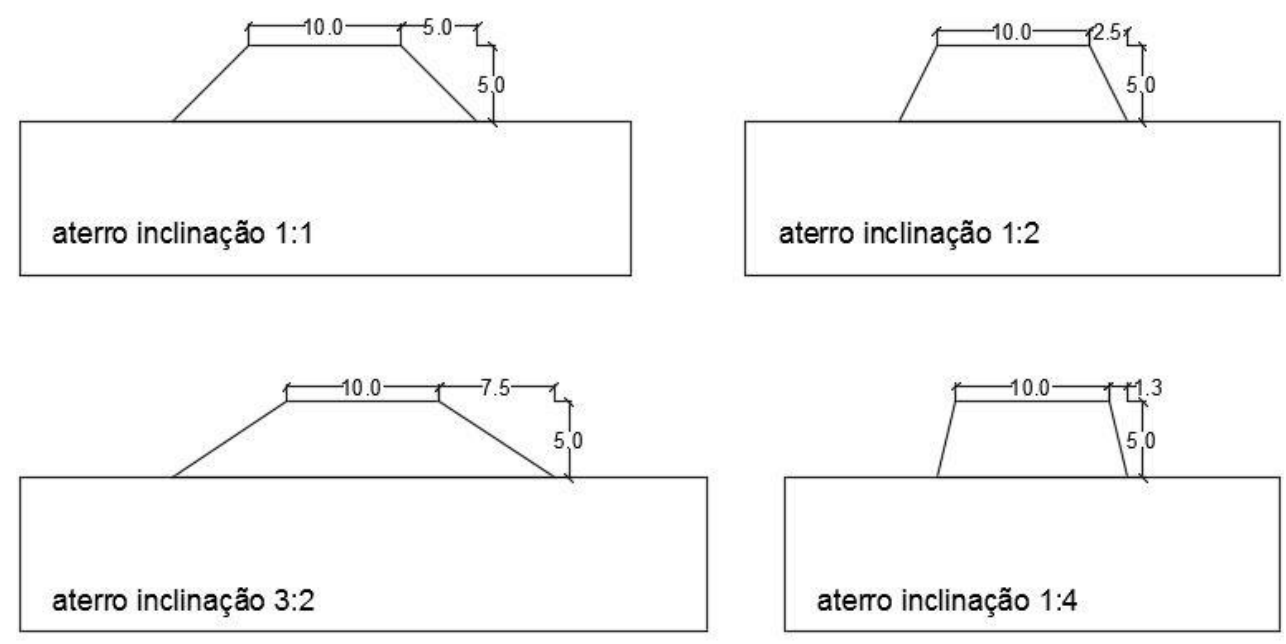

Figura 4 - Seções de aterros hipotéticas com 5 metros de altura
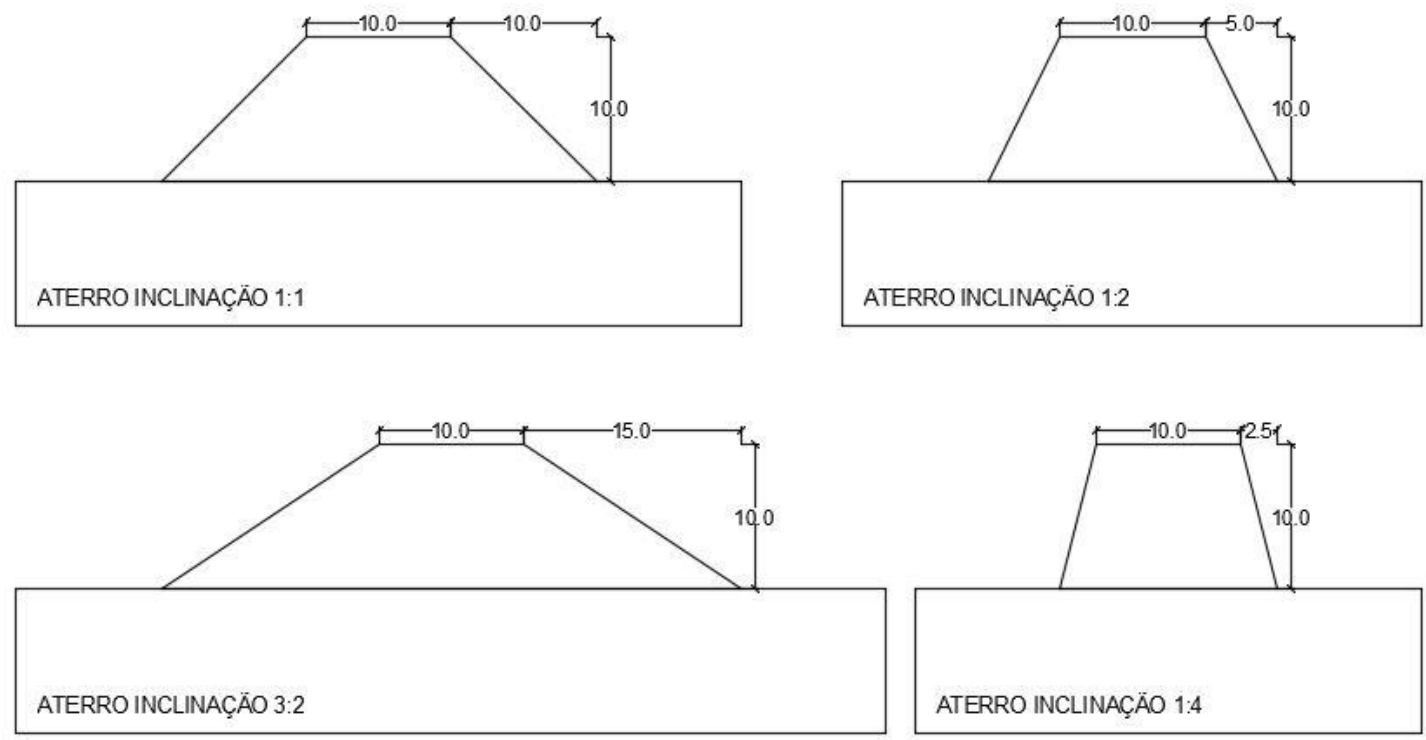

Figura 5 - Seções de aterros hipotéticas com 10 metros de altura
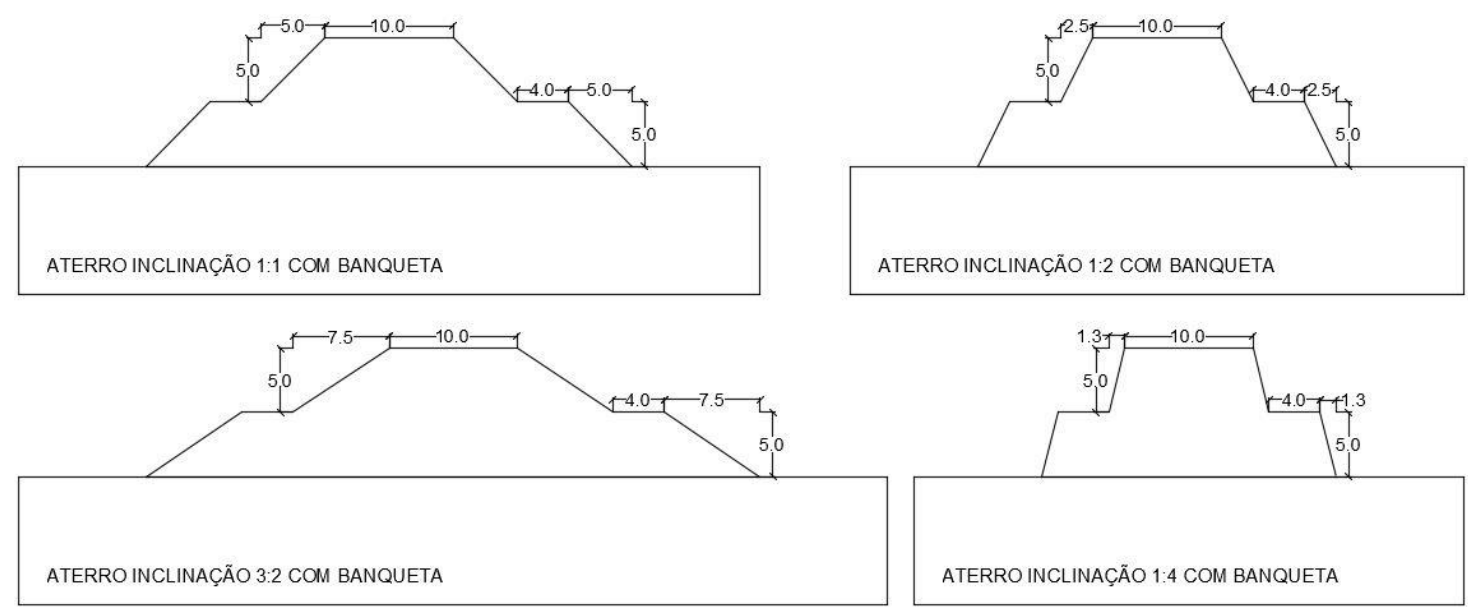

Figura 6 - Seções de aterros hipotéticas com 10 metros de altura e com banquetas de 4 metros 


\section{4 - RESULTADOS E DISCUSSÃO}

\section{1 - Ensaios de caracterização do solo}

A classificação tátil visual da amostra apontava um material com características Areia-argilosa, com pouca umidade e cor marrom avermelhada sem presença de pedregulho e com uma pequena porcentagem de Silte. Foi obtida a umidade higroscópica da amostra, feito o peneiramento, sedimentação, Limite de Plasticidade e Limite de Liquidez

Nos resultados dos ensaios de granulometria por sedimentação, ocorreu diferença em relação a curva granulométrica sem defloculante que mostra o nível de agregação dos solos lateríticos de Brasília.

\subsection{1 - Ensaio de granulometria sem defloculante}

Tabela 4 - Umidade higroscópica e Massa específica dos grãos

\begin{tabular}{|c|c|c|c|c|c|c|c|}
\hline \multirow{2}{*}{\multicolumn{4}{|c|}{ Umidade higroscópica }} & \multicolumn{4}{|c|}{ Massa especifica dos grãos \# 2mm } \\
\hline & & & & \multirow{2}{*}{$\begin{array}{l}\text { Ensaio com picnômetro: } \\
\text { Picnômetro } \mathrm{N}^{\circ}\end{array}$} & \multirow{2}{*}{$\begin{array}{l}\mathrm{A} \\
1\end{array}$} & \multirow{2}{*}{$\begin{array}{l}\text { B } \\
2\end{array}$} & \multirow{2}{*}{$\begin{array}{c}\mathrm{C} \\
11\end{array}$} \\
\hline${\text { Capsula } N^{\circ}}^{\circ}$ & 13 & 17 & 31 & & & & \\
\hline tara $(g)$ & 13,60 & 12,90 & 12,82 & Temperatura $\left({ }^{\circ} \mathrm{C}\right)$ & 21,5 & 21,5 & 21,7 \\
\hline tara + SH (g) & 85,82 & 89,63 & 76,23 & Pic. + água (g) & 669,83 & 694,46 & $\begin{array}{l}703,7 \\
0\end{array}$ \\
\hline tara + SS (g) & 85,62 & 89,40 & 76,06 & Pic. + água + solo(g) & 701,52 & 726,23 & $\begin{array}{l}735,4 \\
2\end{array}$ \\
\hline Umidade (\%) & 0,28 & 0,30 & 0,27 & $\mathrm{G}(\mathrm{g} / \mathrm{cm} 3)$ & 2,74 & 2,75 & 2,74 \\
\hline & & w (\%): & 0,28 & & & $\mathbf{G}_{\mathbf{s}}$ & 2,74 \\
\hline
\end{tabular}

Massa da amostra seca ao $\operatorname{ar} \mathbf{M}_{\mathbf{t}}(\mathrm{g})=1000$

Massa total da amostra seca $\mathbf{M}_{\mathbf{s}}(\mathrm{g})=\quad \mathbf{9 9 7 , 2 0}$

Tabela 5 - Peneiramento Grosso e Peneiramento fino da amostra

\begin{tabular}{|c|c|c|c|c|}
\hline \multicolumn{5}{|c|}{ Peneiramento Grosso } \\
\hline Peneira & Abertura(mm) & Solo retido(g) & Solo retido acumulado(g) & $\%$ de material que passa \\
\hline $2^{\prime \prime}$ & 50,8 & $\mathbf{0 , 0 0}$ & 0,00 & 100,0000 \\
\hline $11 / 2^{\prime \prime}$ & 38,1 & $\mathbf{0 , 0 0}$ & 0,00 & 100,0000 \\
\hline $1 "$ & 25,4 & $\mathbf{0 , 0 0}$ & 0,00 & 100,0000 \\
\hline $3 / 4 "$ & 19,1 & $\mathbf{0 , 0 0}$ & 0,00 & 100,0000 \\
\hline $3 / 8^{\prime \prime}$ & 9,5 & $\mathbf{0 , 0 0}$ & 0,00 & 100,0000 \\
\hline 4 & 4,76 & $\mathbf{0 , 8 5}$ & 0,85 & 99,9148 \\
\hline 10 & 2,00 & $\mathbf{4 , 7 5}$ & 5,60 & 99,4384 \\
\hline
\end{tabular}

\begin{tabular}{|c|c|c|c|c|}
\hline \multicolumn{5}{|c|}{ Peneiramento Fino } \\
\hline Peneira & Abertura(mm) & Solo retido(g) & Solo retido acumulado(g) & \% de material que passa \\
\hline 16 & 1,19 & $\mathbf{0 , 5 4}$ & 0,54 & 98,7 \\
\hline 30 & 0,59 & $\mathbf{2 , 6 7}$ & 3,21 & 94,9 \\
\hline 40 & 0,42 & $\mathbf{4 , 6 8}$ & 7,89 & 88,2 \\
\hline 60 & 0,25 & $\mathbf{1 6 , 1 5}$ & 24,04 & 65,2 \\
\hline 100 & 0,149 & $\mathbf{2 3 , 0 1}$ & 47,05 & 32,4 \\
\hline 200 & 0,074 & $\mathbf{1 2 , 1 6}$ & 59,21 & 15,1 \\
\hline
\end{tabular}


Tabela 6 - Dados referente à Sedimentação

\begin{tabular}{|c|c|c|c|c|c|c|c|}
\hline \multicolumn{8}{|c|}{ SEDIMENTAÇÃO } \\
\hline \multicolumn{5}{|c|}{ Massa do material úmido submetido à sedimentação $\mathbf{M}_{\mathbf{h}}(\mathrm{g})=$} & 70 & Densímetro $\mathrm{n}^{\circ}$ : & $59884 / 08$ \\
\hline tempo & tempo (s) & temp. $\left({ }^{\circ} \mathrm{C}\right)$ & $\mathrm{L}\left(\mathrm{g} / \mathrm{cm}^{\wedge} 3\right)$ & $\mathrm{Ld}\left(\mathrm{g} / \mathrm{cm}^{\wedge} 3\right)$ & $a(\mathrm{~cm})$ & QS (\%) & $d(\mathrm{~mm})$ \\
\hline $30 \mathrm{~s}$ & 30 & 27,0 & 1,0010 & 0,9970 & 15,2 & 9,0 & 0,0676 \\
\hline $1 \mathrm{~min}$. & 60 & 27,0 & 1,0000 & 0,9970 & 15,4 & 6,7 & 0,0480 \\
\hline $2 \mathrm{~min}$. & 120 & 27,0 & 0,9990 & 0,9970 & 15,5 & 4,5 & 0,0341 \\
\hline $4 \mathrm{~min}$. & 240 & 25,0 & 0,9997 & 0,9976 & 14,7 & 4,7 & 0,0240 \\
\hline $8 \mathrm{~min}$. & 480 & 25,2 & 0,9997 & 0,9975 & 14,7 & 4,9 & 0,0170 \\
\hline $15 \mathrm{~min}$. & 900 & 25,4 & 0,9990 & 0,9975 & 14,8 & 3,4 & 0,0124 \\
\hline $30 \mathrm{~min}$. & 1800 & 25,2 & 0,9990 & 0,9975 & 14,8 & 3,3 & 0,0088 \\
\hline $1 \mathrm{~h}$ & 3600 & 25,3 & 0,9985 & 0,9975 & 14,9 & 2,2 & 0,0062 \\
\hline $2 \mathrm{~h}$ & 7200 & 26,0 & 0,9985 & 0,9973 & 14,9 & 2,7 & 0,0044 \\
\hline $4 \mathrm{~h}$ & 14400 & 26,0 & 0,9983 & 0,9973 & 15,0 & 2,3 & 0,0031 \\
\hline $8 \mathrm{~h}$ & 28800 & 27,7 & 0,9980 & 0,9968 & 15,0 & 2,7 & 0,0021 \\
\hline $24 \mathrm{~h}$ & 86400 & 24,7 & 0,9989 & 0,9977 & 14,9 & 2,7 & 0,0013 \\
\hline
\end{tabular}

\begin{tabular}{|c|c|c|c|c|}
\hline $\mathrm{d}(\mathrm{mm})$ & $\begin{array}{l}\% \text { mat. } \\
\text { passa }\end{array}$ & $\%$ mat.ret. & MATERIAL* & $\%$ do material \\
\hline 50,80 & 100,0 & 0,0 & \multirow{3}{*}{$20,0<$ Pedregulho grosso $<60,0$} & \multirow{3}{*}{0,0} \\
\hline 38,10 & 100,0 & 0,0 & & \\
\hline 25,40 & 100,0 & 0,0 & & \\
\hline 19,10 & 100,0 & 0,0 & \multirow{2}{*}{$6,0<$ Pedregulho médio $<20,0$} & \multirow{2}{*}{0,1} \\
\hline 9,52 & 100,0 & 0,0 & & \\
\hline 4,76 & 99,9 & 0,1 & \multirow{2}{*}{$2,0<$ Pedregulho fino $<6,0$} & \multirow{2}{*}{0,5} \\
\hline 2,00 & 99,4 & 0,6 & & \\
\hline 1,190 & 98,7 & 1,3 & $0,6<$ Areia grossa $<2,0$ & 4,5 \\
\hline 0,590 & 94,9 & 5,1 & \multirow{3}{*}{$0,2<$ Areia média $<0,6$} & \multirow{3}{*}{46,0} \\
\hline 0,420 & 88,2 & 11,8 & & \\
\hline 0,250 & 65,2 & 34,8 & & \\
\hline 0,149 & 32,4 & 67,6 & \multirow{3}{*}{$0,06<$ Areia fina $<0,2$} & \multirow{3}{*}{40,9} \\
\hline 0,074 & 15,1 & 84,9 & & \\
\hline 0,0676 & 9,0 & 91,0 & & \\
\hline 0,0480 & 6,7 & 93,3 & \multirow{10}{*}{$0,002<$ Silte $<0,06$} & \multirow{10}{*}{5,4} \\
\hline 0,0341 & 4,5 & 95,5 & & \\
\hline 0,0240 & 4,7 & 95,3 & & \\
\hline 0,0170 & 4,9 & 95,1 & & \\
\hline 0,0124 & 3,4 & 96,6 & & \\
\hline 0,0088 & 3,3 & 96,7 & & \\
\hline 0,0062 & 2,2 & 97,8 & & \\
\hline 0,0044 & 2,7 & 97,3 & & \\
\hline 0,0031 & 2,3 & 97,7 & & \\
\hline 0,0021 & 2,7 & 97,3 & & \\
\hline 0,0013 & 2,7 & 97,3 & Argila $<0,002$ & 2,7 \\
\hline \multicolumn{4}{|c|}{ ABNT - NBR 6502, Rochas e Solos - setembro 1995 ( unidade em mm) } & 100,0 \\
\hline
\end{tabular}


Tabela 7 - Porcentaaens do material que constitui a amotr

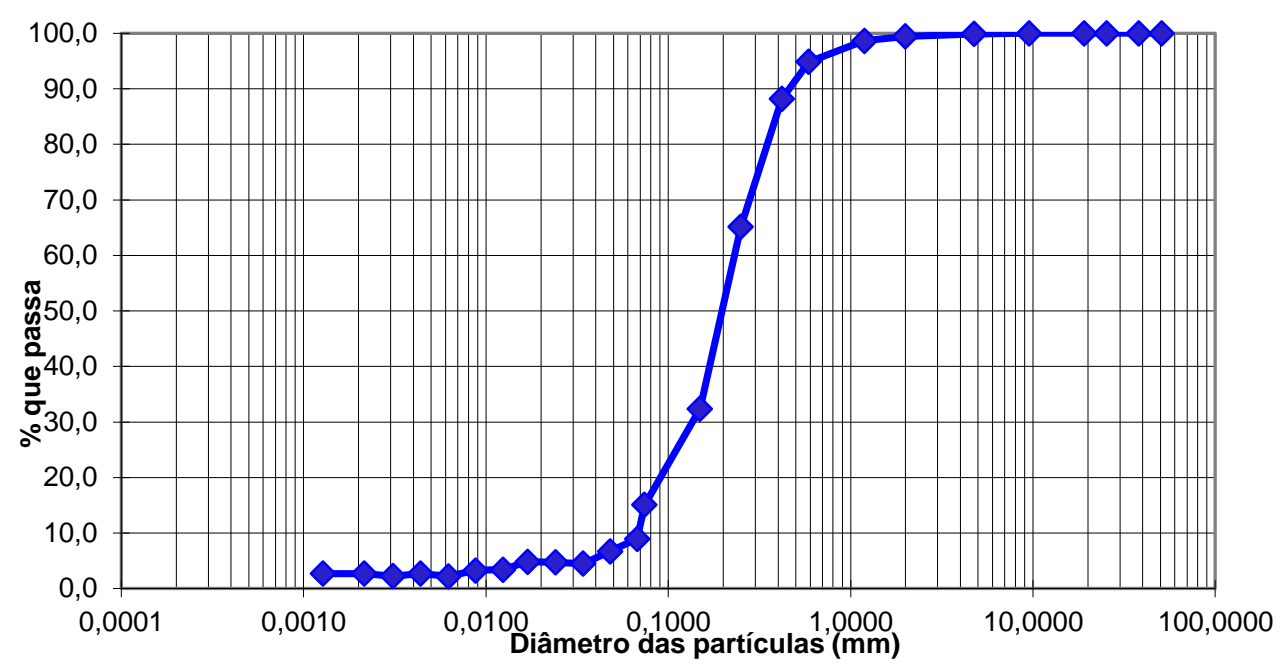

Figura 7 - Curva granulométrica sem defloculante

\subsection{2 - Ensaio de granulometria com defloculante}

Tabela 8 - Umidade higroscópica e Massa específica dos grãos

\begin{tabular}{|l|c|c|c|l|c|c|c|}
\hline \multicolumn{4}{|c|}{ Umidade higroscópica } & \multicolumn{3}{c|}{ Massa especifica dos grãos \# 2mm } \\
\cline { 5 - 8 } & & Ensaio com picnômetro: & $\mathrm{A}$ & $\mathrm{B}$ & $\mathrm{C}$ \\
\hline Capsula N $^{\circ}$ & 13 & 17 & 31 & Picnômetro N & 1 & 2 & 11 \\
\hline tara $(\mathrm{g})$ & 13,60 & 12,90 & 12,82 & Temperatura $\left({ }^{\circ} \mathrm{C}\right)$ & 21,5 & 21,5 & 21,7 \\
\hline tara + SH (g) & 85,82 & 89,63 & 76,23 & Pic. + água $(\mathrm{g})$ & 669,83 & 694,46 & 703,70 \\
\hline tara + SS (g) & 85,62 & 89,40 & 76,06 & Pic. + água + solo(g) & 701,52 & 726,23 & 735,42 \\
\hline Umidade (\%) & 0,28 & 0,30 & 0,27 & G ( g/cm3) & 2,74 & 2,75 & 2,74 \\
\hline
\end{tabular}

Massa da amostra seca ao ar $\mathbf{M}_{\mathbf{t}}(\mathrm{g})=1000$

Massa total da amostra seca $\mathbf{M}_{\mathbf{s}}(\mathrm{g})=\quad \mathbf{9 9 7 , 2 0}$

Tabela 9 - Peneiramento Grosso e Peneiramento fino da amostra

\begin{tabular}{|c|c|c|c|c|}
\hline \multicolumn{5}{|c|}{ Peneiramento Grosso } \\
\hline Peneira & Abertura(mm) & Solo retido(g) & Solo retido acumulado(g) & $\%$ de material que passa \\
\hline $2 "$ & 50,8 & $\mathbf{0 , 0 0}$ & 0,00 & 100,0000 \\
\hline $11 / 2^{\prime \prime}$ & 38,1 & $\mathbf{0 , 0 0}$ & 0,00 & 100,0000 \\
\hline $1^{\prime \prime}$ & 25,4 & $\mathbf{0 , 0 0}$ & 0,00 & 100,0000 \\
\hline $3 / 4^{\prime \prime}$ & 19,1 & $\mathbf{0 , 0 0}$ & 0,00 & 100,0000 \\
\hline $3 / 8^{\prime \prime}$ & 9,5 & $\mathbf{0 , 0 0}$ & 0,00 & 100,0000 \\
\hline 4 & 4,76 & $\mathbf{0 , 8 5}$ & 0,85 & 99,9148 \\
\hline 10 & 2,00 & $\mathbf{4 , 7 5}$ & 5,60 & 99,4384 \\
\hline
\end{tabular}

\begin{tabular}{|c|c|c|c|c|}
\hline \multicolumn{5}{|c|}{ Peneiramento Fino } \\
\hline Peneira & Abertura(mm) & Solo retido(g) & Solo retido acumulado(g) & \% de material que passa \\
\hline 16 & 1,19 & $\mathbf{0 , 3 0}$ & 0,30 & 99,0 \\
\hline 30 & 0,59 & $\mathbf{1 , 3 4}$ & 1,64 & 97,1 \\
\hline 40 & 0,42 & $\mathbf{2 , 0 3}$ & 3,67 & 94,2 \\
\hline 60 & 0,25 & $\mathbf{8 , 5 7}$ & 12,24 & 82,0 \\
\hline
\end{tabular}




\begin{tabular}{|l|l|l|l|l|}
\cline { 4 - 5 } 100 & 0,149 & $\mathbf{1 7 , 0 2}$ & 29,26 & 57,8 \\
\hline 200 & 0,074 & $\mathbf{1 2 , 0 7}$ & 41,33 & 40,6 \\
\hline
\end{tabular}

Tabela 10 - Dados referente a Sedimentação

\begin{tabular}{|c|c|c|c|c|c|c|c|}
\hline \multicolumn{8}{|c|}{ SEDIMENTAÇÃO } \\
\hline \multicolumn{5}{|c|}{$\begin{array}{c}\text { Massa do material úmido submetido à sedimentação } \mathbf{M}_{\mathrm{h}}(\mathrm{g}) \\
=\end{array}$} & 70 & Densímetro $\mathrm{n}^{\circ}$ : & $59884 / 08$ \\
\hline tempo & tempo (s) & temp. $\left({ }^{\circ} \mathrm{C}\right)$ & $\mathrm{L}\left(\mathrm{g} / \mathrm{cm}^{\wedge} 3\right)$ & $\mathrm{Ld}\left(\mathrm{g} / \mathrm{cm}^{\wedge} 3\right)$ & $a(\mathrm{~cm})$ & QS (\%) & $\mathrm{d}(\mathrm{mm})$ \\
\hline $30 \mathrm{~s}$ & 30 & 26,0 & 1,0200 & 1,0048 & 12,2 & 34,2 & 0,0612 \\
\hline $1 \mathrm{~min}$. & 60 & 26,0 & 1,0180 & 1,0048 & 12,5 & 29,7 & 0,0438 \\
\hline $2 \mathrm{~min}$. & 120 & 26,0 & 1,0170 & 1,0048 & 12,7 & 27,4 & 0,0312 \\
\hline $4 \mathrm{~min}$. & 240 & 26,0 & 1,0162 & 1,0048 & 12,1 & 25,6 & 0,0215 \\
\hline $8 \mathrm{~min}$. & 480 & 26,1 & 1,0160 & 1,0047 & 12,1 & 25,2 & 0,0152 \\
\hline $15 \mathrm{~min}$. & 900 & 26,0 & 1,0155 & 1,0048 & 12,2 & 24,1 & 0,0112 \\
\hline $30 \mathrm{~min}$. & 1800 & 26,0 & 1,0150 & 1,0048 & 12,3 & 22,9 & 0,0079 \\
\hline $1 \mathrm{~h}$ & 3600 & 25,9 & 1,0147 & 1,0048 & 12,3 & 22,2 & 0,0056 \\
\hline $2 \mathrm{~h}$ & 7200 & 25,8 & 1,0130 & 1,0048 & 12,6 & 18,4 & 0,0040 \\
\hline $4 \mathrm{~h}$ & 14400 & 26,4 & 1,0130 & 1,0047 & 12,6 & 18,6 & 0,0028 \\
\hline $8 \mathrm{~h}$ & 28800 & 27,6 & 1,0128 & 1,0044 & 12,6 & 18,7 & 0,0020 \\
\hline $24 \mathrm{~h}$ & 86400 & 24,6 & 1,0120 & 1,0050 & 12,8 & 15,6 & 0,0012 \\
\hline
\end{tabular}

Tabela 11 - Porcentagens do material que constitui a amostra

\begin{tabular}{|c|c|c|c|c|}
\hline $\mathrm{d}(\mathrm{mm})$ & $\begin{array}{l}\% \text { mat. } \\
\text { passa }\end{array}$ & $\%$ mat.ret. & MATERIAL* & $\%$ do material \\
\hline 50,80 & 100,0 & 0,0 & \multirow{3}{*}{$20,0<$ Pedregulho gross $0<60,0$} & \multirow{3}{*}{0,0} \\
\hline 38,10 & 100,0 & 0,0 & & \\
\hline 25,40 & 100,0 & 0,0 & & \\
\hline 19,10 & 100,0 & 0,0 & \multirow{2}{*}{$6,0<$ Pedregulho médio $<20,0$} & \multirow{2}{*}{0,1} \\
\hline 9,52 & 100,0 & 0,0 & & \\
\hline 4,76 & 99,9 & 0,1 & \multirow{2}{*}{$2,0<$ Pedregulho fino $<6,0$} & \multirow{2}{*}{0,5} \\
\hline 2,00 & 99,4 & 0,6 & & \\
\hline 1,190 & 99,0 & 1,0 & $0,6<$ Areia grossa $<2,0$ & 2,3 \\
\hline 0,590 & 97,1 & 2,9 & \multirow{3}{*}{$0,2<$ Areia média $<0,6$} & \multirow{3}{*}{27,1} \\
\hline 0,420 & 94,2 & 5,8 & & \\
\hline 0,250 & 82,0 & 18,0 & & \\
\hline 0,149 & 57,8 & 42,2 & \multirow{3}{*}{$0,06<$ Areia fina $<0,2$} & \multirow{3}{*}{36,1} \\
\hline 0,074 & 40,6 & 59,4 & & \\
\hline 0,0612 & 34,2 & 65,8 & & \\
\hline 0,0438 & 29,7 & 70,3 & \multirow{10}{*}{$0,002<$ Silte $<0,06$} & \multirow{10}{*}{15,0} \\
\hline 0,0312 & 27,4 & 72,6 & & \\
\hline 0,0215 & 25,6 & 74,4 & & \\
\hline 0,0152 & 25,2 & 74,8 & & \\
\hline 0,0112 & 24,1 & 75,9 & & \\
\hline 0,0079 & 22,9 & 77,1 & & \\
\hline 0,0056 & 22,2 & 77,8 & & \\
\hline 0,0040 & 18,4 & 81,6 & & \\
\hline 0,0028 & 18,6 & 81,4 & & \\
\hline 0,0020 & 18,7 & 81,3 & & \\
\hline 0,0012 & 15,6 & 84,4 & Argila $<0,002$ & 18,8 \\
\hline \multicolumn{4}{|c|}{ ABNT - NBR 6502, Rochas e Solos - setembro 1995 ( unidade em mm) } & 100,0 \\
\hline
\end{tabular}




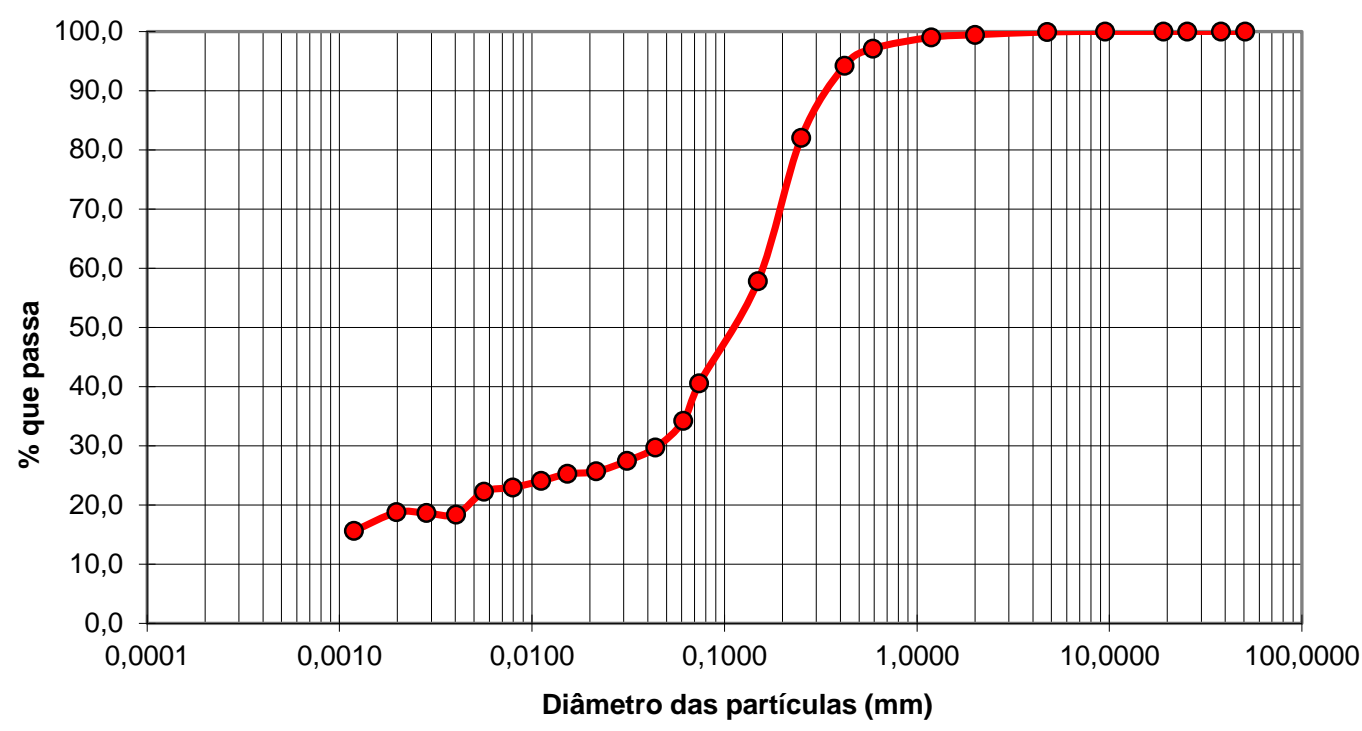

Figura 8 - Curva granulométrica com defloculante

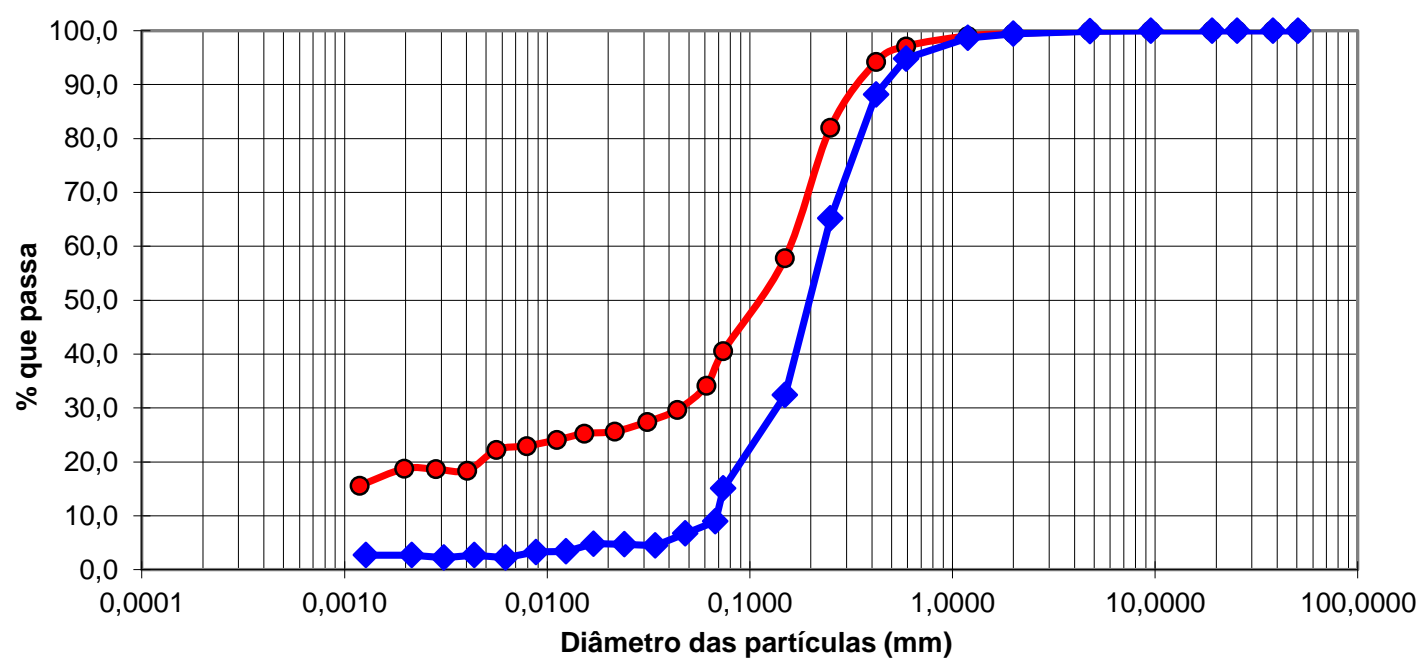

Figura 9 - Curva granulométrica com e sem defloculante

Na Figura 9 se observa a diferença da curva granulométrica com e sem defloculante, apontando um aumento considerável de materiais finos que passantes na peneira. O defloculante age nas partículas do solo desagregando os aglomerados de solo e mostrando a real porcentagem de finos que constitui o material. $\mathrm{Na}$ tabela de materiais que constitui a amostra é possível observar que o solo em estudo é constituído por $27,1 \%$ de areia média, $36,1 \%$ de areia fina e $18,8 \%$ de argila sendo assim um solo denominado de Areia-argilosa. 


\subsection{3 - Limite de Liquidez e Plasticidade}

Tabela 12- Limite de Liquidez e Limite de Plasticidade

\begin{tabular}{|l|c|c|c|c|c|}
\hline \multicolumn{7}{|c|}{ LIMITE DE LIQUIDEZ } \\
\hline $\mathrm{N}^{\circ}$ da capsula & 8 & 1 & 4 & 10 & 7 \\
\hline $\mathrm{N}^{\circ}$ de golpes & 36 & 31 & 26 & 19 & 16 \\
\hline tara (g) & 17,73 & 19,40 & 18,71 & 19,08 & 24,22 \\
\hline tara + SH (g) & 35,84 & 33,05 & 33,40 & 31,56 & 40,09 \\
\hline tara + SS (g) & 30,48 & 28,95 & 28,85 & 27,39 & 34,57 \\
\hline Umidade (\%) & $\mathbf{4 2 , 0 4}$ & $\mathbf{4 2 , 9 3}$ & $\mathbf{4 4 , 8 7}$ & $\mathbf{5 0 , 1 8}$ & $\mathbf{5 3 , 3 3}$ \\
\hline \multicolumn{7}{|l}{} & $\mathbf{W L}(\%):$ & $\mathbf{4 6 , 3 9}$ \\
\hline $\mathrm{N}^{\circ}$ da capsula & LIMITE DE PLASTICIDADE & & \\
\hline tara (g) & 84 & 112 & 109 & 57 & 66 \\
\hline tara + SH (g) & 5,86 & 5,34 & 5,84 & 5,60 & 5,69 \\
\hline tara + SS (g) & 7,61 & 7,18 & 7,89 & 7,66 & 7,65 \\
\hline Umidade (\%) & 7,15 & 6,71 & 7,38 & 7,13 & 7,15 \\
\hline
\end{tabular}

ÍNDICE DE PLASTICIDADE (\%): 112,0

Limite de Liquidez ( Casagrande ) y = -14,34ln $(x)+92,549$ $R^{2}=0,9776$

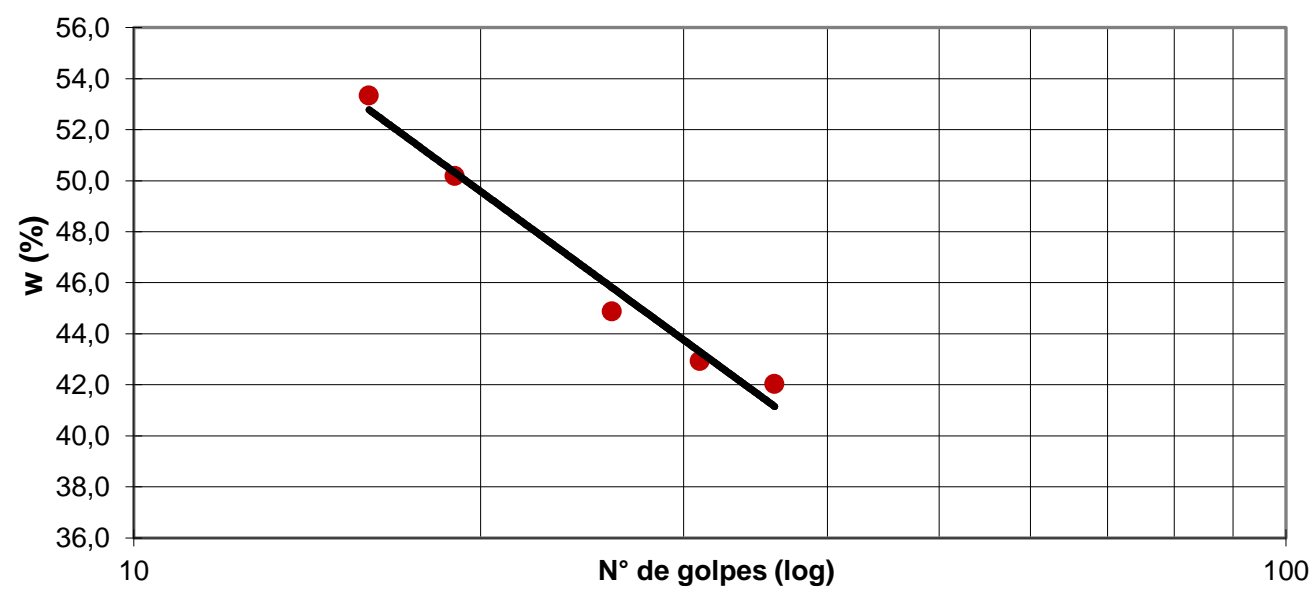

Figura 10 - Limite de Liquidez e Limite de Plasticidade

O material foi submetido ao ensaio de Casagrande e retornou um valor de Índice de Plasticidade igual a 12, que é equivalente a uma plasticidade média.

\section{2 - Ensaios de compactação}

Tabela 13 - Medidas dos cilindros utilizados no ensaio

\begin{tabular}{|c|c|c|c|c|}
\hline Molde N $^{\circ}$ & Altura (cm) & Diâmetro (cm) & Volume $\left(\mathbf{c m}^{\mathbf{3}}\right)$ & Peso $(\mathbf{g})$ \\
\hline HSN 03 & 11,35 & 15,23 & 2067,63 & 4734,7 \\
\hline HSN 09 & 11,41 & 15,22 & 2075,83 & 4596,4 \\
\hline
\end{tabular}




\begin{tabular}{|c|c|c|c|c|}
7 & 11,43 & 15,19 & 2071,28 & 4698,8 \\
\hline 18 & 11,40 & 15,20 & 2068,56 & 4740,5 \\
\hline 3 & 11,42 & 15,21 & 2074,92 & 4666,2 \\
\hline
\end{tabular}

Tabela 14 - Umidade de compactação Proctor Normal

\begin{tabular}{|c|c|c|c|c|c|c|c|}
\hline $\begin{array}{c}\text { Amostra } \\
\text { Compactada }\end{array}$ & cap. $\mathbf{n}^{\circ}$ & $\mathbf{P h}+\mathbf{T}$ & $\mathbf{P s}+\mathbf{T}$ & $\mathbf{T}$ & Umidade & Umidade & $\gamma_{\mathrm{d}\left(\mathrm{kN} / \mathbf{m}^{3}\right)}$ \\
\hline HNS03 & 12 & 81,68 & 73,68 & 13,52 & $\mathbf{1 3 , 3 0}$ & & \\
$\mathbf{8 0 8 2 , 9}$ & D2 & 87,96 & 79,49 & 17,02 & $\mathbf{1 3 , 5 6}$ & $\mathbf{1 3 , 4 2}$ & $\mathbf{1 4 , 0 0}$ \\
& $\mathrm{H} 105$ & 88,27 & 79,72 & 15,98 & $\mathbf{1 3 , 4 1}$ & & \\
\hline HSN09 & 50 & 83,31 & 73,97 & 13,99 & $\mathbf{1 5 , 5 7}$ & & \\
$\mathbf{8 2 4 7 , 9}$ & 17 & 76,18 & 67,46 & 12,79 & $\mathbf{1 5 , 9 5}$ & $\mathbf{1 5 , 7 3}$ & $\mathbf{1 4 , 9 1}$ \\
& 1002 & 77,94 & 69,58 & 16,21 & $\mathbf{1 5 , 6 6}$ & & \\
\hline 7 & 21 & 87,56 & 76,82 & 14,45 & $\mathbf{1 7 , 2 2}$ & & \\
$\mathbf{8 5 8 6 , 6}$ & 24 & 78,76 & 69,15 & 13,17 & $\mathbf{1 7 , 1 7}$ & $\mathbf{1 7 , 2 3}$ & $\mathbf{1 5 , 7 0}$ \\
& 1001 & 87,95 & 77,07 & 14,16 & $\mathbf{1 7 , 2 9}$ & & \\
\hline 18 & $\mathrm{D} 4$ & 86,64 & 75,62 & 15,92 & $\mathbf{1 8 , 4 6}$ & & \\
$\mathbf{8 6 6 5 , 1}$ & 41 & 77,07 & 66,98 & 12,95 & $\mathbf{1 8 , 6 7}$ & $\mathbf{1 8 , 5 3}$ & $\mathbf{1 5 , 8 6}$ \\
& $\mathrm{H} 102$ & 97,48 & 84,78 & 15,96 & $\mathbf{1 8 , 4 5}$ & & \\
\hline 3 & 43 & 102,96 & 87,45 & 13,50 & $\mathbf{2 0 , 9 7}$ & \multirow{2}{*}{$\mathbf{2 0}$} & \multirow{2}{*}{$\mathbf{1 5}$} \\
$\mathbf{8 6 2 3 , 9}$ & 32 & 94,40 & 80,75 & 14,37 & $\mathbf{2 0 , 5 6}$ & $\mathbf{2 0 , 8 0}$ & $\mathbf{2 0}$ \\
& $\mathrm{D} 1$ & 103,29 & 88,20 & 15,85 & $\mathbf{2 0 , 8 6}$ & & \\
\hline
\end{tabular}

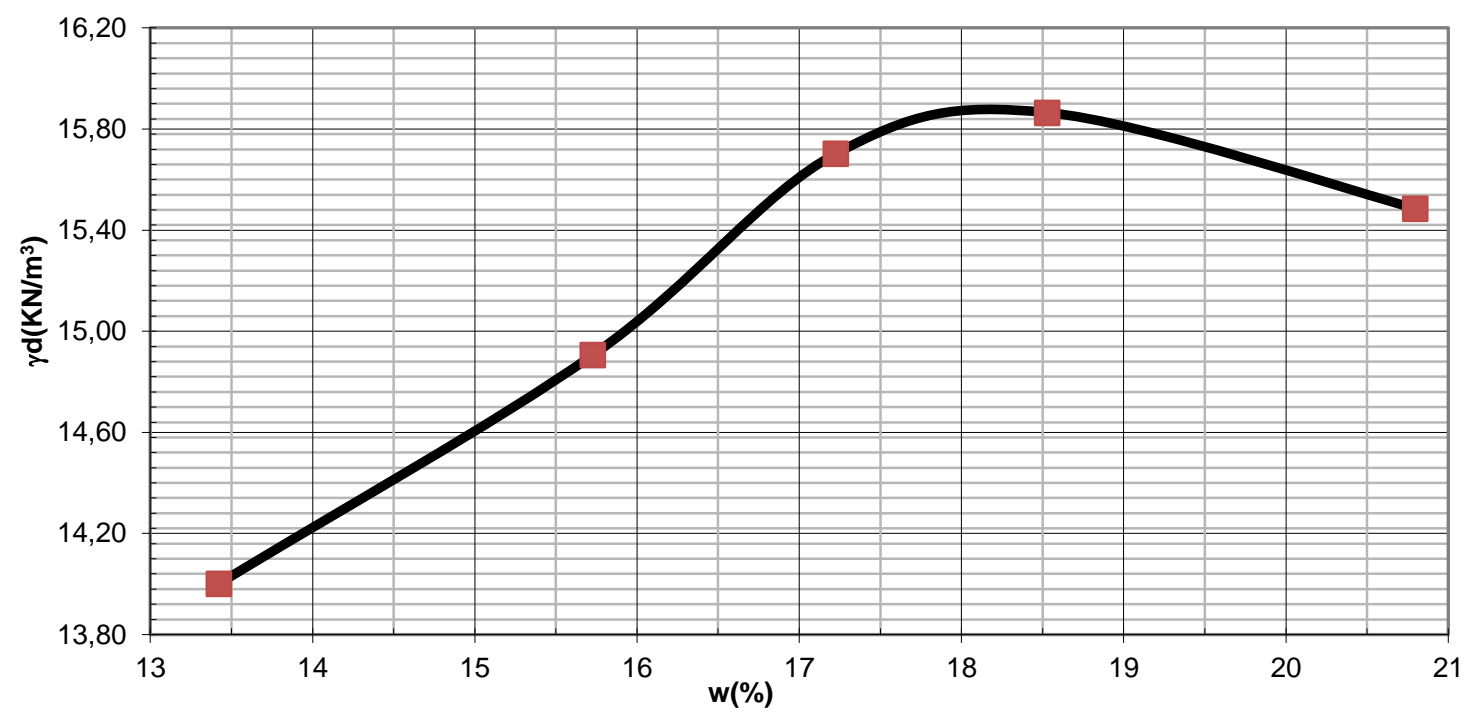

Figura 11 - Curva de compactação

Para as análises do software é necessário utilizar o peso específico natural do solo que foi encontrado a partir da fórmula:

$$
\gamma d=\frac{\gamma \text { nat }}{1+W}
$$

Resultando em: 
Para Umidade ótima $(18,2) \gamma d=15,85$ e $\gamma$ nat $=18,73$

Para Umidade ótima $-2 \%(16,2) \gamma d=15,25$ e ynat $=17,72$

Para Umidade ótima $+2 \%(20,2) \gamma d=15,55$ e $\gamma$ nat $=18,69$

Para Umidade ótima $-4 \%(14,2) \gamma d=14,35$ e ynat $=16,39$

Para Umidade ótima $+4 \%(22,2) \gamma d=15,15$ e $\gamma$ nat $=18,51$

\section{3 - Ensaios de cisalhamento direto}

O corpo de prova foi moldado em um anel quadrado de metal com 2 centímetros de altura e 5,08 centímetros de lado, totalizando uma área de $25,81 \mathrm{~cm}^{2}$ que foi submetido ao ensaio de cisalhamento.

A partir dos resultados obtidos dos ensaios de cisalhamento foram elaborados os gráficos da tensão cisalhante e as envoltórias de resistência. As figuras a seguir apresentam os gráficos elaborados.

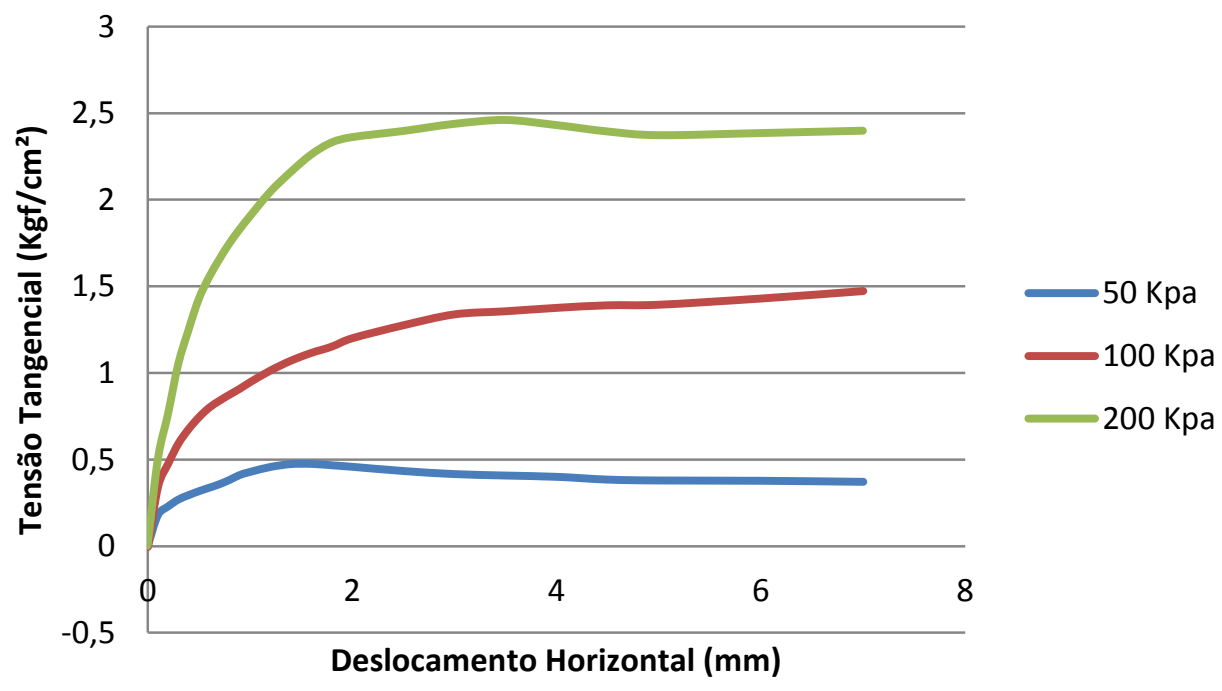

Figura 12 - Curvas de tensão cisalhante $x$ deslocamento (umidade ótima)

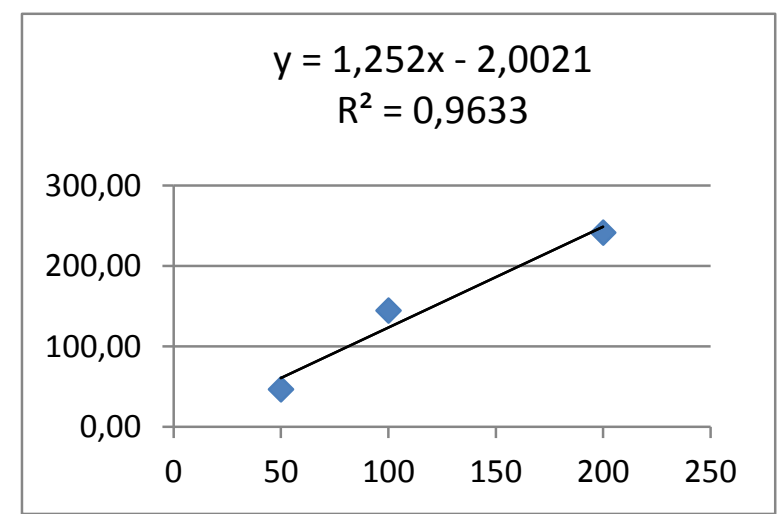

Figura 13 - Linha de tendência (Tensão Normal x Tensão Cisalhante)

\begin{tabular}{|c|c|}
\hline Tensão Normal (kPa) & Tensão Cisalhante (kPa) \\
\hline 50 & 46,49 \\
\hline 100 & 144,36 \\
\hline 200 & 241,34 \\
\hline
\end{tabular}

\begin{tabular}{|l|l|}
\hline Ângulo de Atrito $\boldsymbol{\phi}$ & $51,38^{\circ}$ \\
\hline Coesão & $2,0021 \mathrm{kPa}$ \\
\hline
\end{tabular}

Figura 14 - Tensão Cisalhante máxima de cada curva, ângulo de atrito e coesão $2 \varepsilon$ 


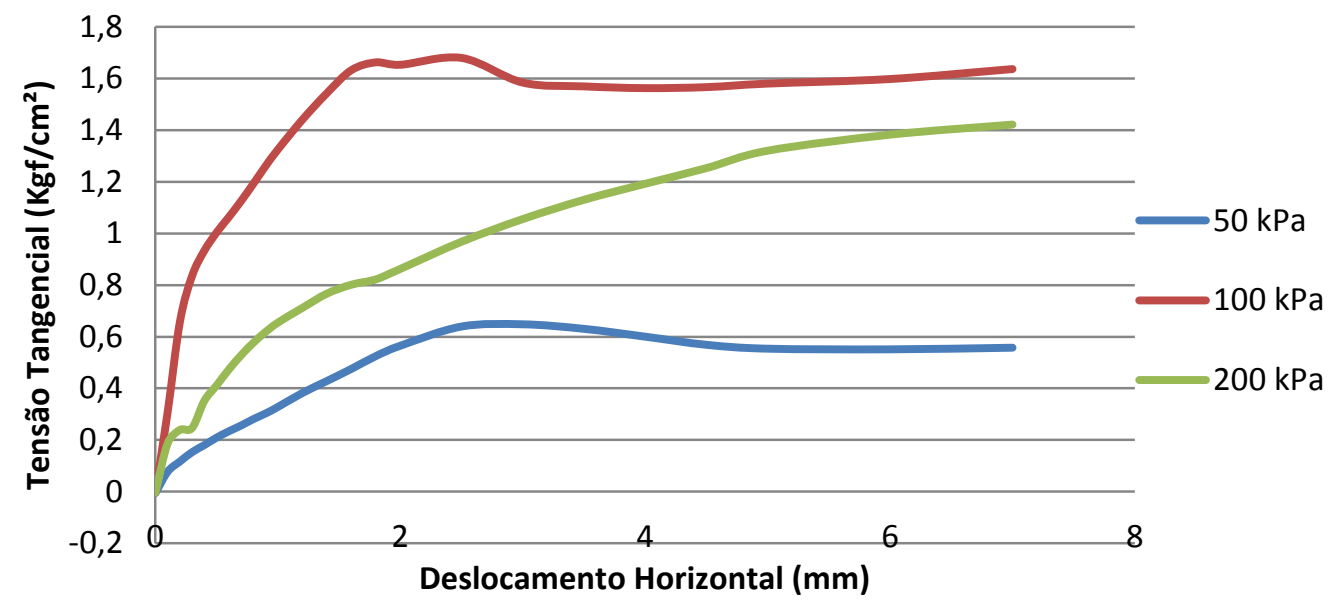

Figura 15 - Curvas de tensão cisalhante x deslocamento (umidade ótima $-4 \%$ )

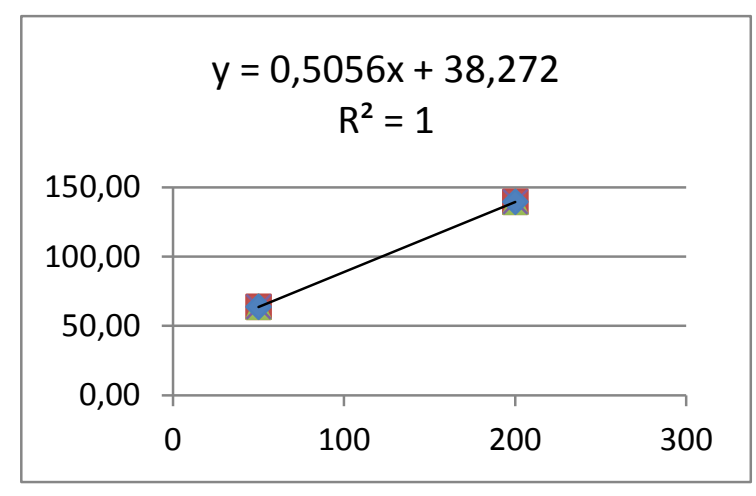

Figura 16 - Linha de tendência (Tensão Normal x Tensão Cisalhante)

\begin{tabular}{|c|c|}
\hline Tensão Normal (kPa) & Tensão Cisalhante (kPa) \\
\hline 50 & 63,55 \\
\hline 100 & 164,69 \\
\hline 200 & 194,00 \\
\hline
\end{tabular}

\begin{tabular}{|l|l|}
\hline Ângulo de Atrito $\boldsymbol{\phi}$ & $21,66^{\circ}$ \\
\hline Coesão & 38,272 \\
\hline
\end{tabular}

Figura 17 - Tensão Cisalhante máxima de cada curva, ângulo de atrito e coesão

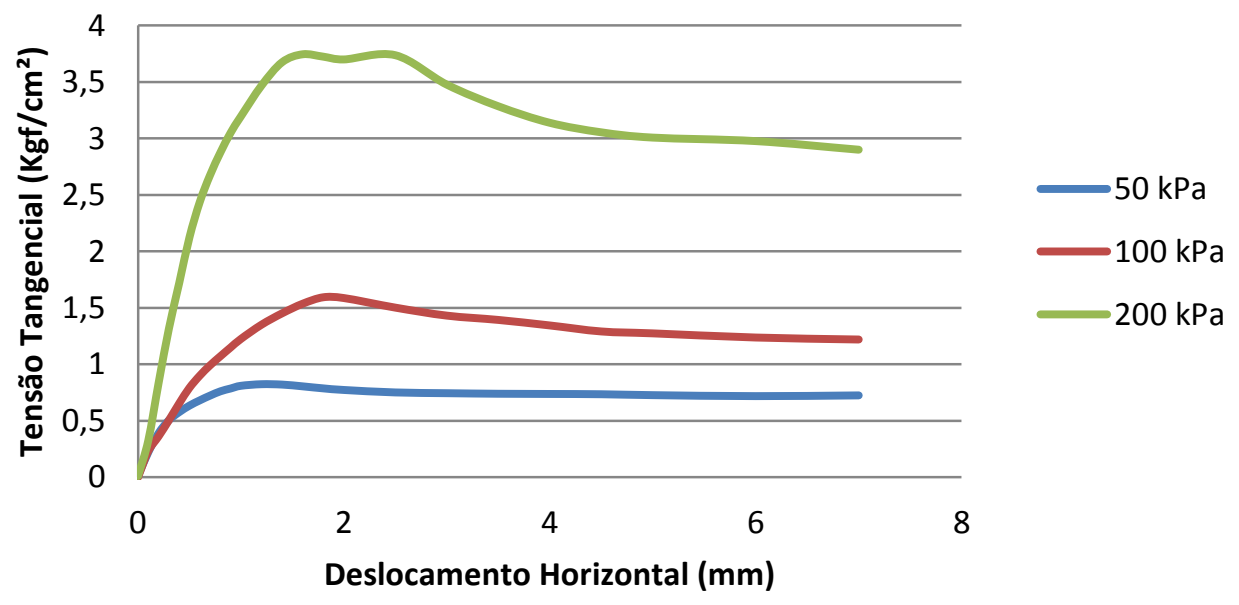

Figura 18 - Curvas de tensão cisalhante x deslocamento (umidade ótima -2\%) 


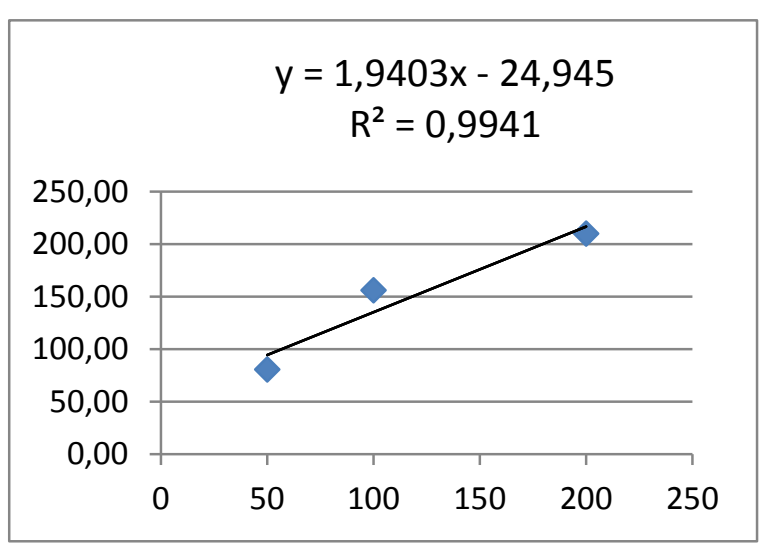

Figura 19 - Linha de tendência (Tensão Normal x Tensão Cisalhante)

\begin{tabular}{|c|c|}
\hline Tensão Normal (kPa) & Tensão Cisalhante (kPa) \\
\hline 50 & 80,70 \\
\hline 100 & 156,14 \\
\hline 200 & 210,00 \\
\hline
\end{tabular}

\begin{tabular}{|l|l|}
\hline Ângulo de Atrito $\boldsymbol{\phi}$ & $62,73^{\circ}$ \\
\hline Coesão & $-24,945 \mathrm{kPa}$ \\
\hline
\end{tabular}

Figura 20 - Tensão Cisalhante máxima de cada curva, ângulo de atrito e coesão

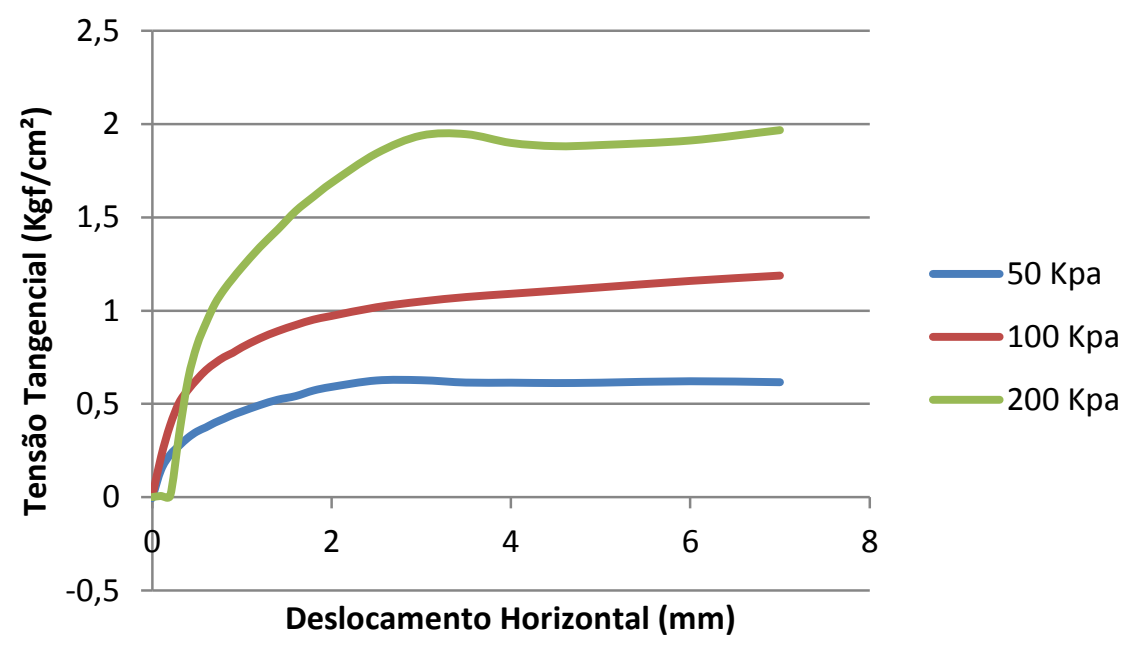

Figura 21 - Curvas de tensão cisalhante x deslocamento (umidade ótima $+2 \%$ )

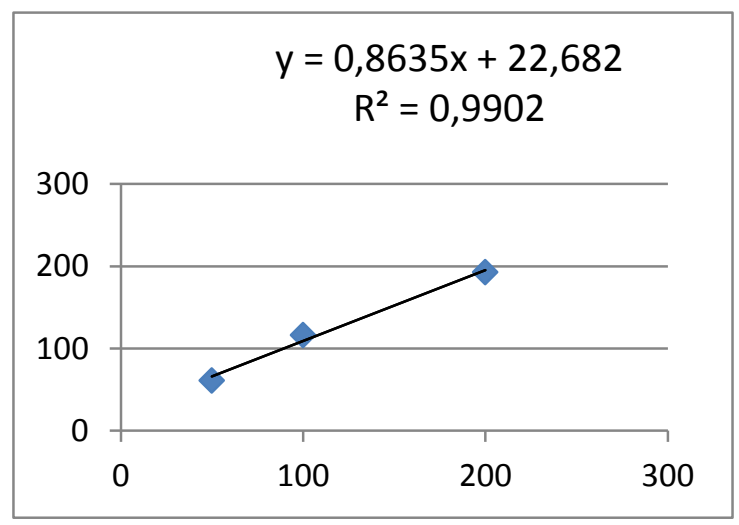

Figura 22 - Linha de tendência (Tensão Normal x Tensão Cisalhante)

\begin{tabular}{|c|c|}
\hline Tensão Normal (kPa) & Tensão Cisalhante (kPa) \\
\hline 50 & 60,89 \\
\hline 100 & 116,48 \\
\hline 200 & 192,90 \\
\hline
\end{tabular}

\begin{tabular}{|l|l|}
\hline Ângulo de Atrito $\boldsymbol{\phi}$ & $40,81^{\circ}$ \\
\hline Coesão & $22,682 \mathrm{kPa}$ \\
\hline
\end{tabular}

Figura 23 - Tensão Cisalhante máxima de cada curva, ângulo de atrito e coesão 


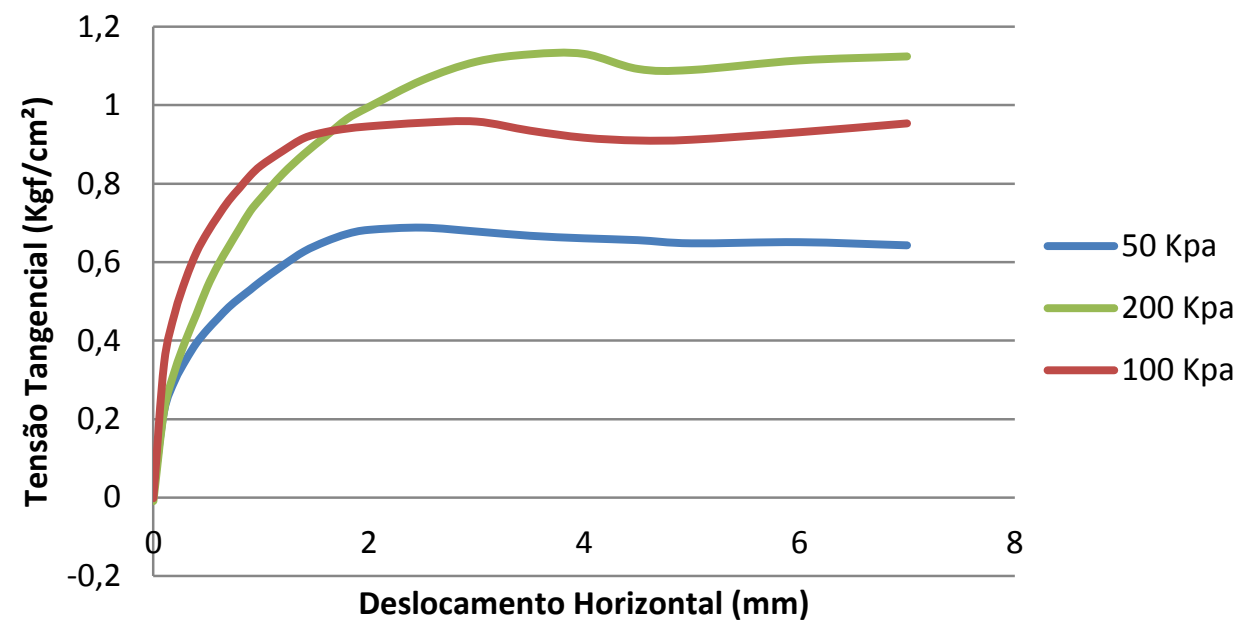

Figura 24 - Curvas de tensão cisalhante x deslocamento (umidade ótima $+4 \%$ )

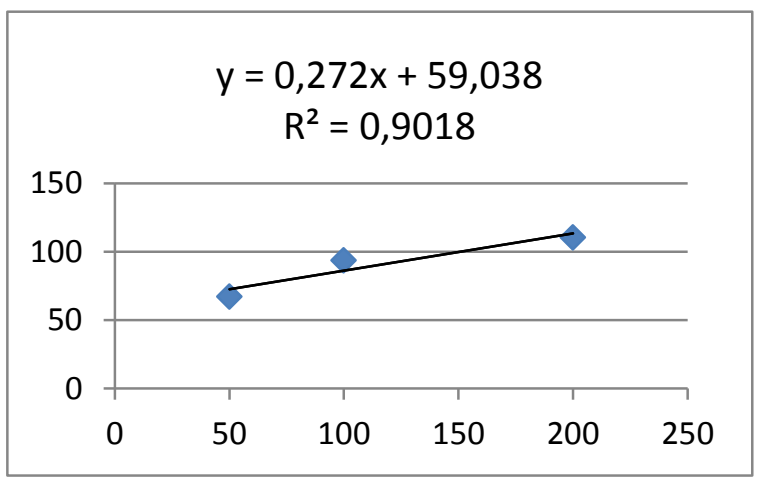

Figura 25 - Linha de tendência (Tensão Normal x Tensão Cisalhante)

\begin{tabular}{|c|c|}
\hline Tensão Normal (kPa) & Tensão Cisalhante (kPa) \\
\hline 50 & 47,00 \\
\hline 100 & 94,02 \\
\hline 200 & 110,85 \\
\hline
\end{tabular}

\begin{tabular}{|l|l|}
\hline Ângulo de Atrito $\boldsymbol{\phi}$ & $15,22^{\circ}$ \\
\hline Coesão & $59,038 \mathrm{kPa}$ \\
\hline
\end{tabular}

Figura 26 - Tensão Cisalhante máxima de cada curva, ângulo de atrito e coesão

A envoltória de resistência foi definida a partir das Tensões de Cisalhamento máximo da cada ensaio da envoltória, onde foi criado um gráfico dos pontos de Tensão Cisalhante versus Tensão Normal por onde foram traçados linhas de tendência que permitiram por meio das equações das retas determinar o ângulo de atrito e a coesão das amostras ensaiadas como mostram as Figuras anteriores.

É importante ressaltar que os valores de ângulo de atrito e coesão obtidos são para amostras compactadas na condição de umidade de compactação sem saturação, por esse motivo os valores de atrito são muito altos já que o solo tropical de Brasília quando compactado atinge resistências elevadas.

\section{4 - Adaptações dos dados da campanha experimental}

Os resultados obtidos na campanha experimental foram ajustados com base no conhecimento do solo local em condições de compactação semelhantes. 
A incompatibilidade com a realidade desta situação, pode ter ocorrido devido a imprecisões ou imperfeições na realização dos ensaios. Desta feita, levando em consideração o conhecimento das características dos solos, foram excluídos pontos que se afastavam do padrão das curvas, Os parâmetros finais adotados para as simulações se apresentam a seguir.

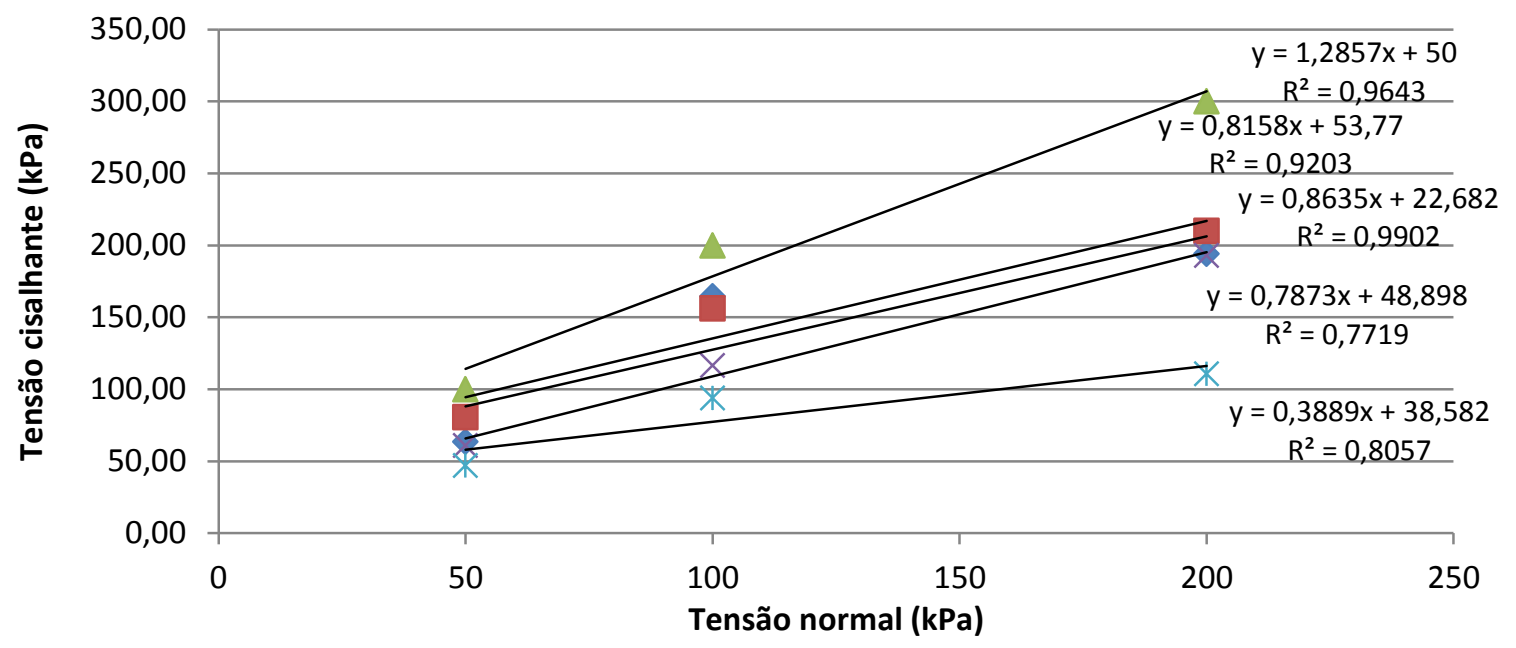

Figura 27 - Linhas de tendência referente a todas as umidades

\begin{tabular}{|r|r|r|r|r|}
\hline \multicolumn{1}{|l|}{ Desvio de umidade } & Umidade real & Umidade prevista & Coesão & \multicolumn{2}{l|}{ Atrito } \\
\hline 0,01 & 14,19 & 14,20 & 48,8 & 38 \\
\hline 0,42 & 15,78 & 16,20 & 53 & 39 \\
\hline 1,08 & 17,12 & 18,20 & 50 & 52 \\
\hline 0,43 & 20,63 & 20,20 & 22,6 & 40 \\
\hline 0,58 & 21,62 & 22,20 & 38,5 & 21 \\
\hline
\end{tabular}

Figura 28 - Dados utilizados para análise de estabilidade de talude

Na Figura 29 se apresenta como varia a coesão e o ângulo de atrito para diferentes umidades de compactação.

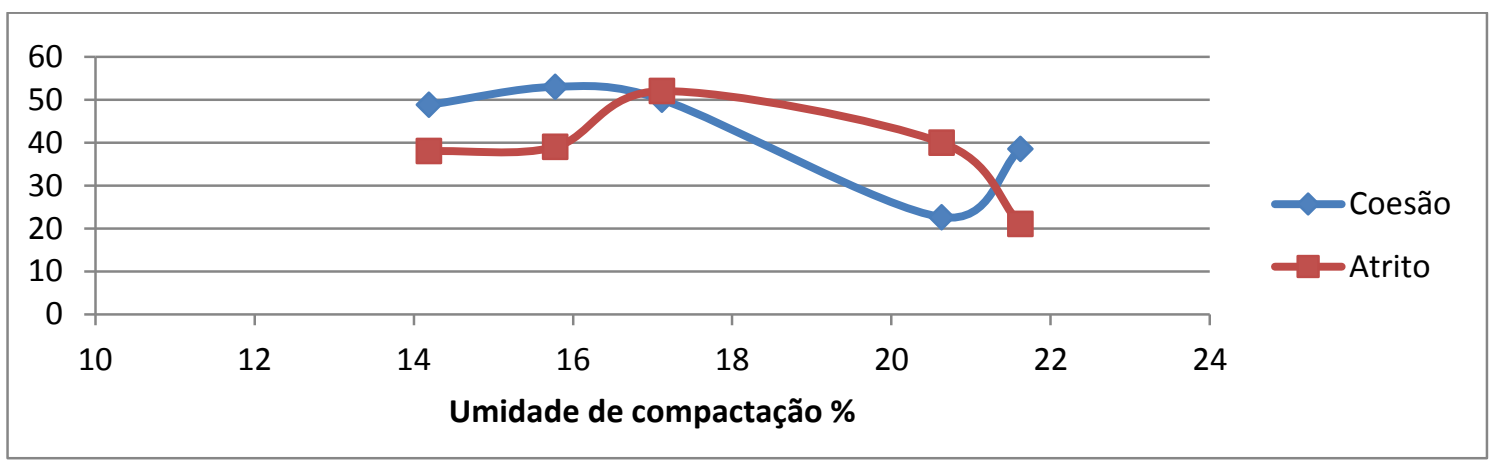

Figura 29 - Curva de Coesão e ângulo de atrito x Umidade de compactação 


\section{5 - Análises no software GeoSlope}

Após analisar os dados da campanha experimental e definir os parâmetros que seriam utilizados para caracterizar o aterro rodoviário foram definidos os parâmetros da base do aterro de maneira que a base dispusesse de ótimas características em que dificilmente poderia ocorrer ruptura.

Para padronizar a fundação do aterro em um cenário otimista foram adotados parâmetros altos para que se pudesse analisar apenas o comportamento do aterro sem que houvesse interferência da qualidade do solo da base, tendo em vista que o objeto de estudo é unicamente a seção hipotética de uma seção de aterro rodoviário que sofrerá alterações de inclinação e de umidade de compactação.

Desta forma, ao trabalhar com cinco níveis de umidade e com doze tipos de seção, foram feitas 60 análises no software GeoSlope com o solo da base sendo um Silte-arenoso com $45^{\circ}$ de ângulo de atrito, $30 \mathrm{kPa}$ de coesão e o material do aterro sendo uma Areia-argilosa com suas características variando de acordo com os dados da campanha experimental como mostram as figuras a seguir.

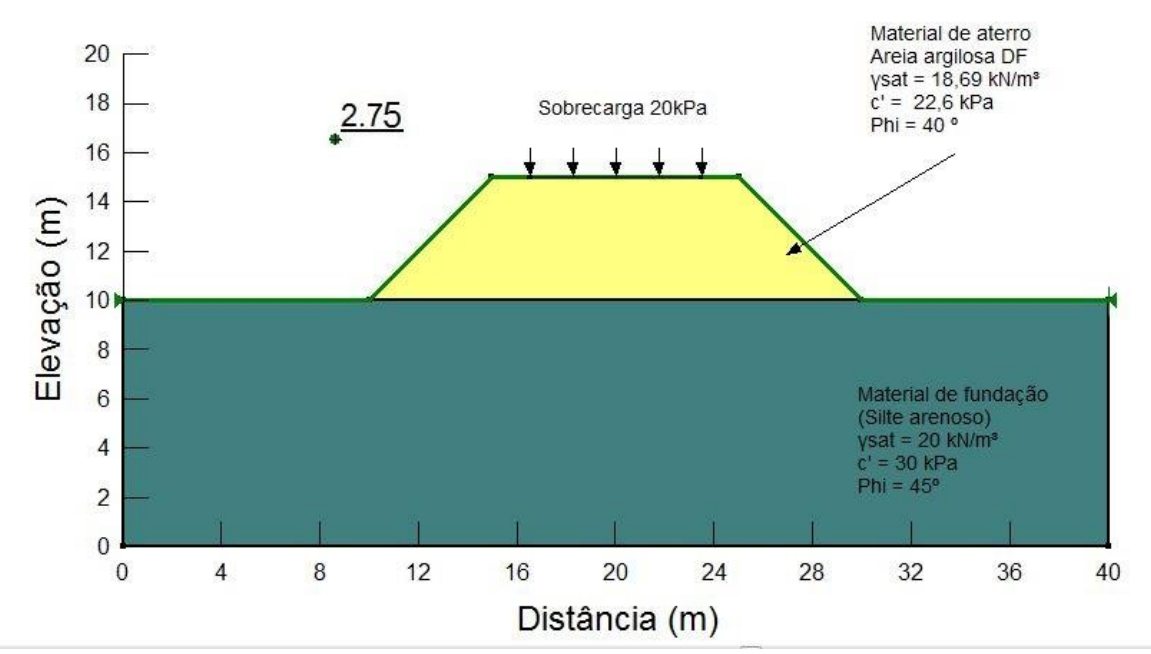

Figura 30 - Aterro de 5 metros com inclinação 1:1 e umidade ótima $+2 \%$

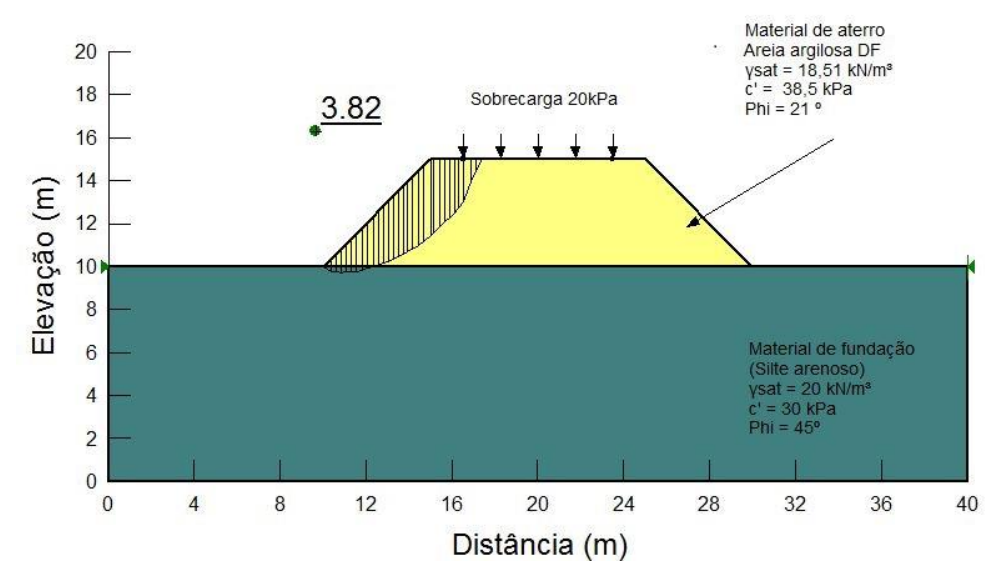

Figura 31 - Aterro de 5 metros com inclinação 1:1 e umidade ótima $+4 \%$ 


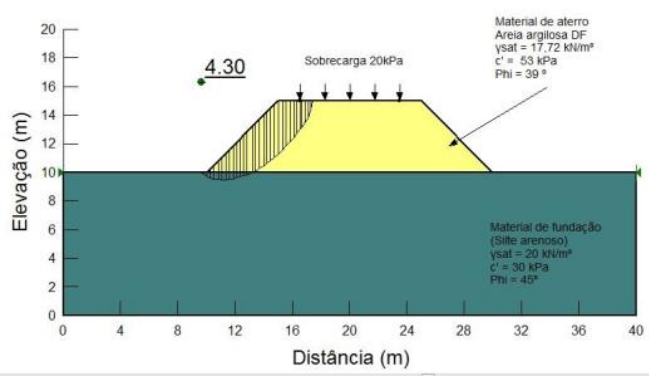

Figura 32 - Aterro de 5 metros com inclinação 1:1 e umidade ótima -2\%

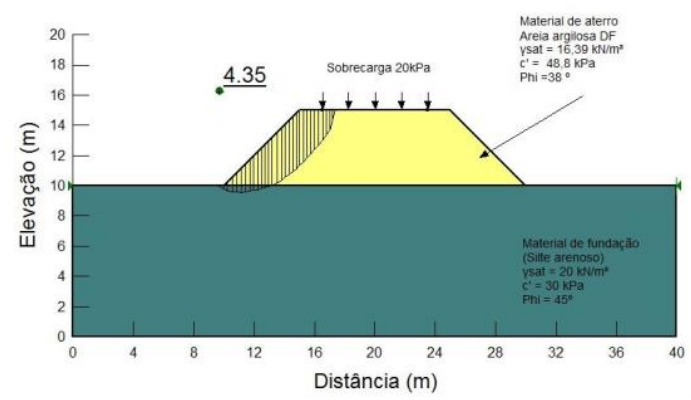

Figura 33 - Aterro de 5 metros com inclinação 1:1 e umidade ótima -4\%

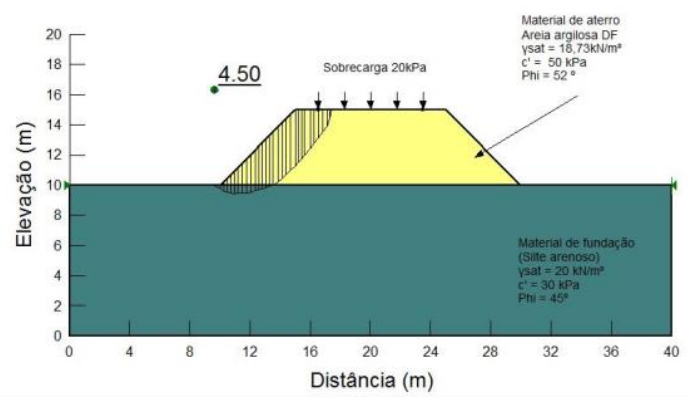

Figura 34 - Aterro de 5 metros com inclinação 1:1 e umidade ótima

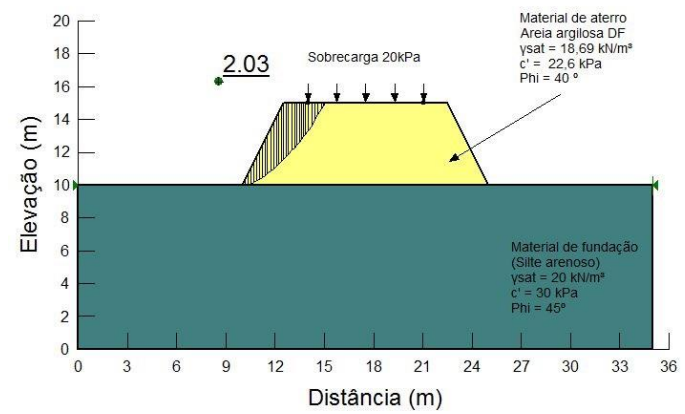

Figura 35 - Aterro de 5 metros com inclinação 1:2 e umidade ótima $+2 \%$

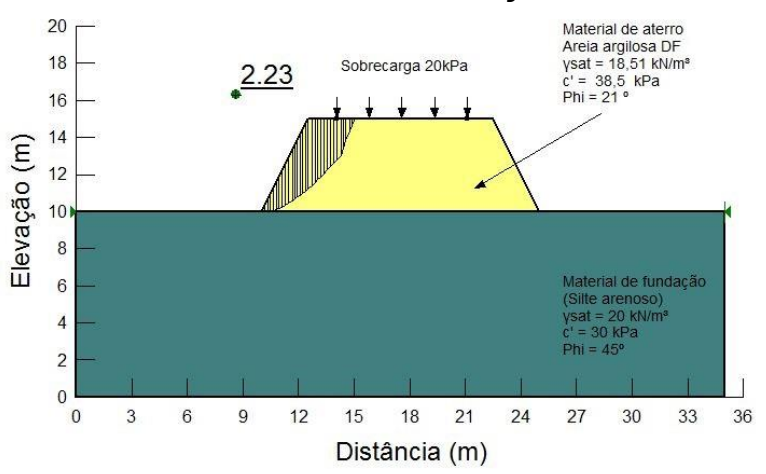

Figura 36 - Aterro de 5 metros com inclinação 1:2 e umidade ótima $+4 \%$ 


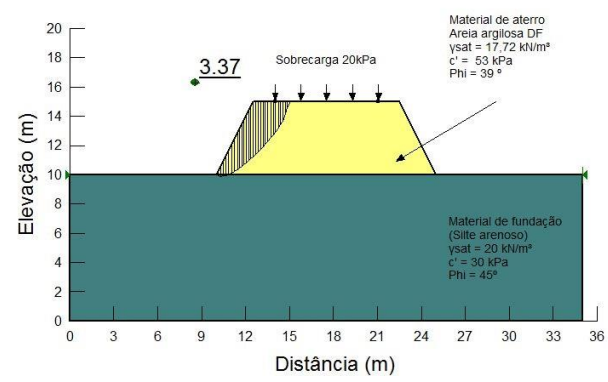

Figura 37 - Aterro de 5 metros com inclinação 1:2 e umidade ótima -2\%

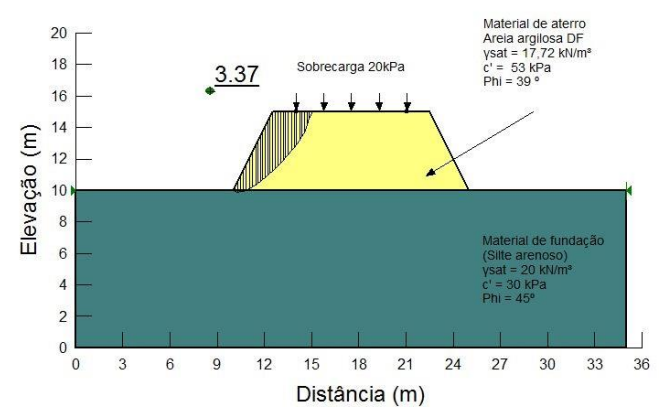

Figura 38 - Aterro de 5 metros com inclinação 1:2 e umidade ótima -4\%

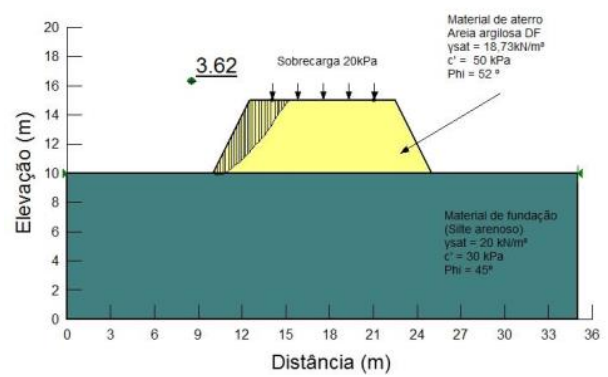

Figura 39 - Aterro de 5 metros com inclinação 1:2 e umidade ótima

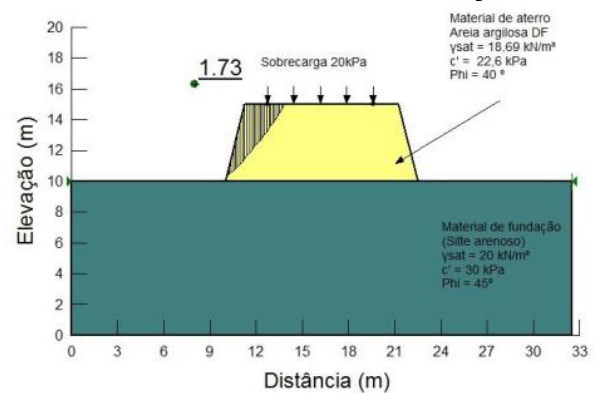

Figura 40 - Aterro de 5 metros com inclinação 1:4 e umidade ótima +2\%

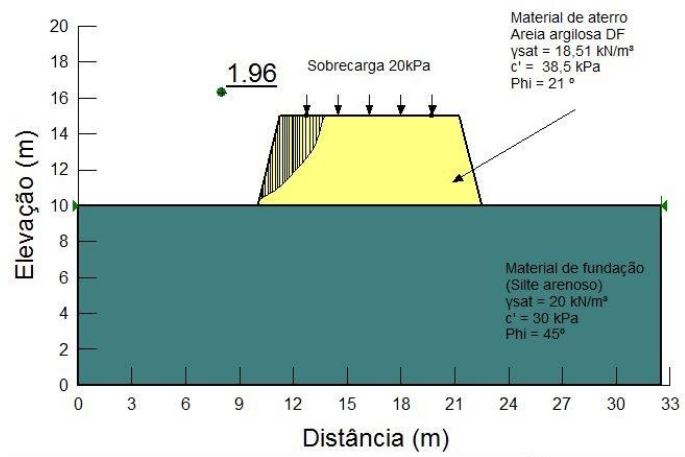

Figura 41 - Aterro de 5 metros com inclinação 1:4 e umidade ótima +4\% 


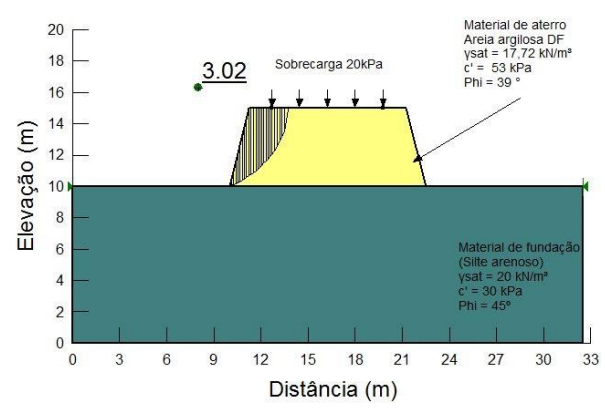

Figura 42 - Aterro de 5 metros com inclinação 1:4 e umidade ótima -2\%

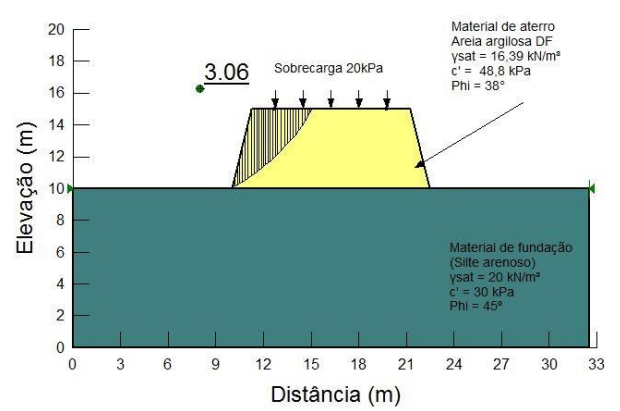

Figura 43 - Aterro de 5 metros com inclinação 1:4 e umidade ótima -4\%

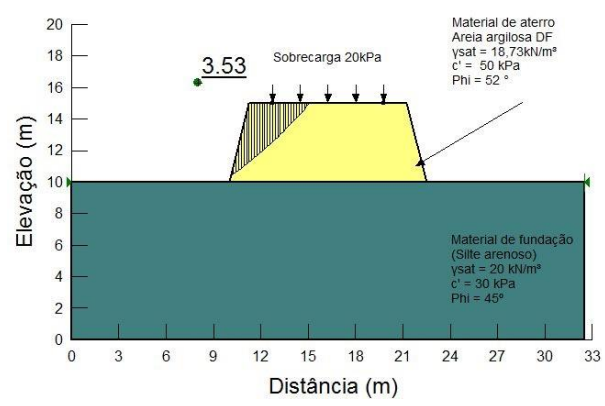

Figura 44 - Aterro de 5 metros com inclinação 1:4 e umidade ótima

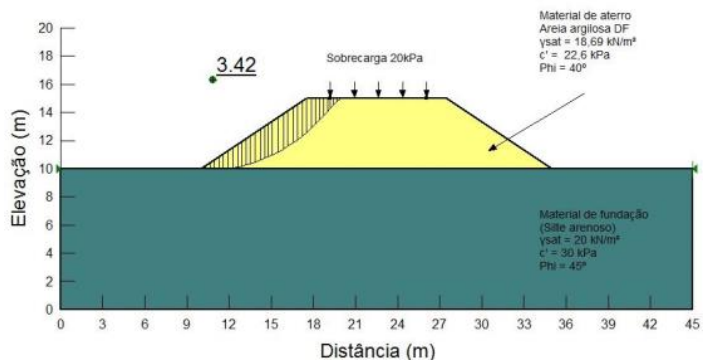

Figura 45 - Aterro de 5 metros com inclinação $3: 2$ e umidade ótima $+2 \%$

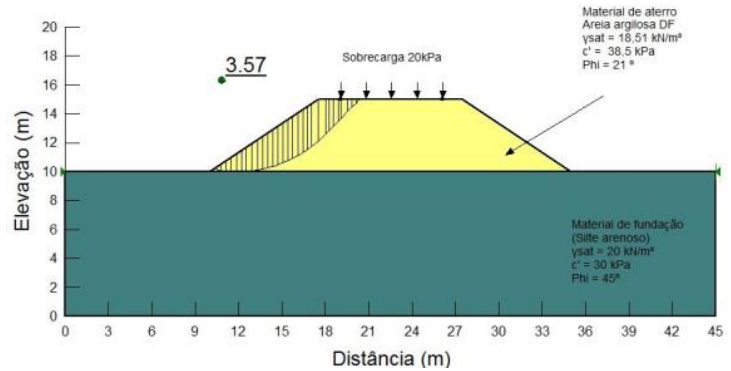

Figura 46 - Aterro de 5 metros com inclinação 3:2 e umidade ótima +4\% 


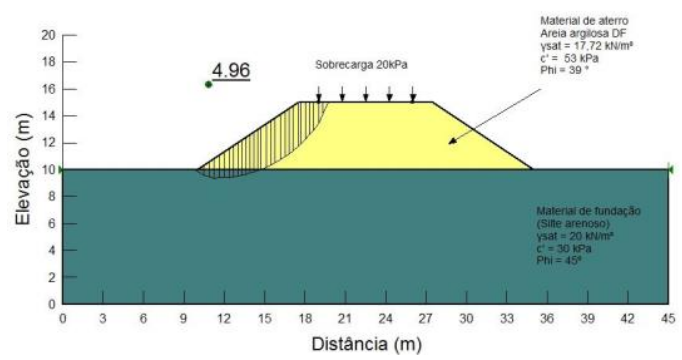

Figura 47 - Aterro de 5 metros com inclinação 3:2 e umidade ótima -2\%

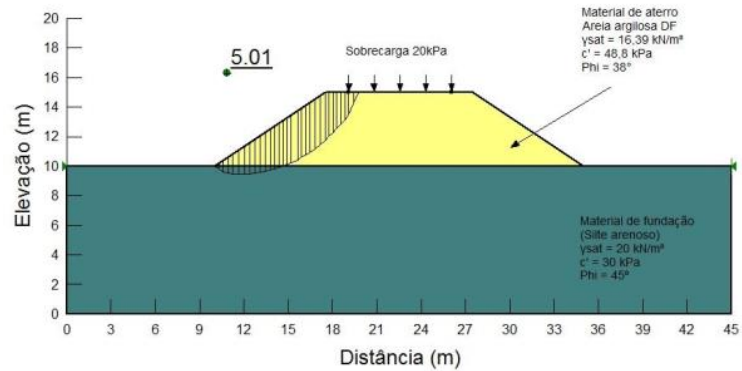

Figura 48 - Aterro de 5 metros com inclinação 3:2 e umidade ótima -4\%

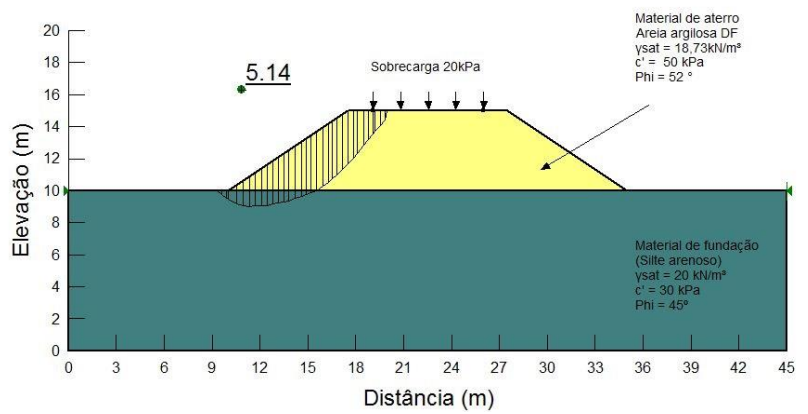

Figura 49 - Aterro de 5 metros com inclinação 3:2 e umidade ótima

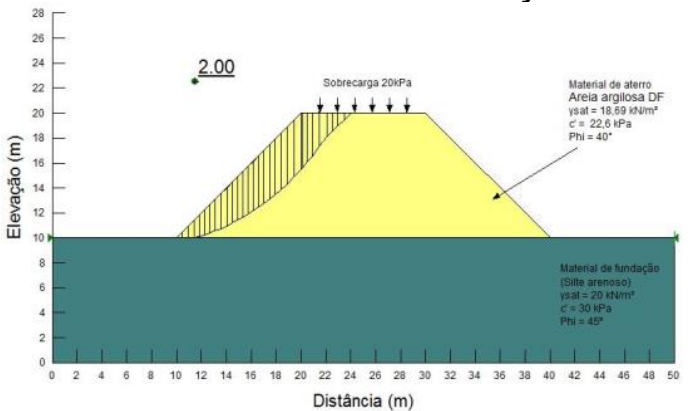

Figura 50 - Aterro de 10 metros com inclinação 1:1 e umidade ótima +2\%

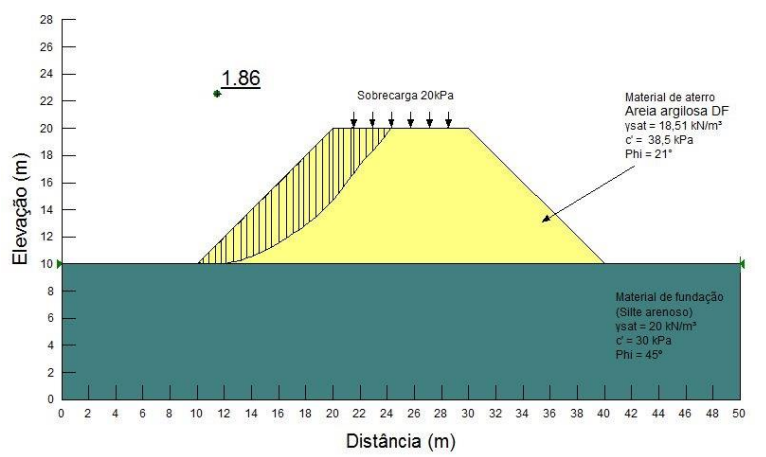

Figura 51 - Aterro de 10 metros com inclinação 1:1 e umidade ótima +4\% 


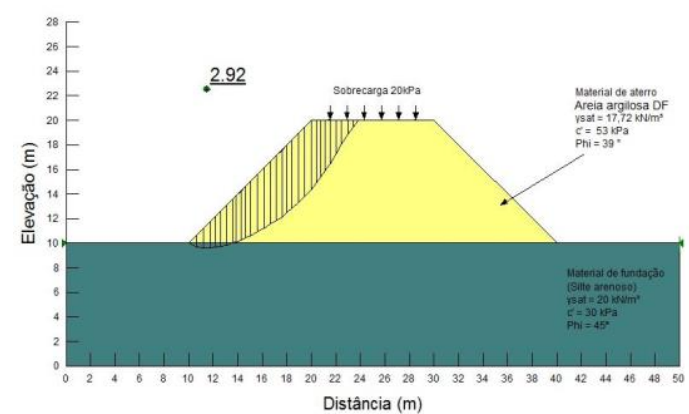

Figura 52 - Aterro de 10 metros com inclinação 1:1 e umidade ótima -2\%

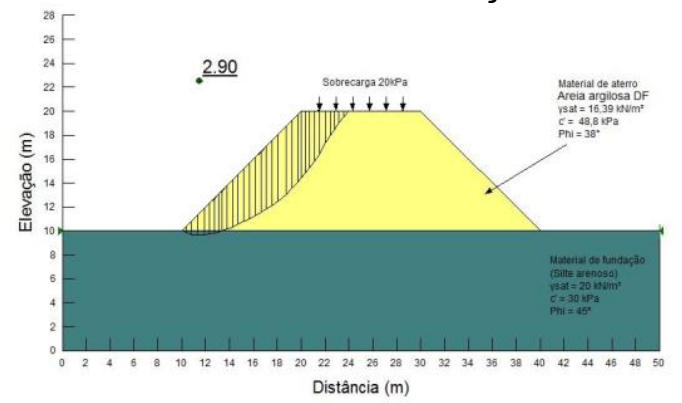

Figura 53 - Aterro de 10 metros com inclinação 1:1 e umidade ótima -4\%

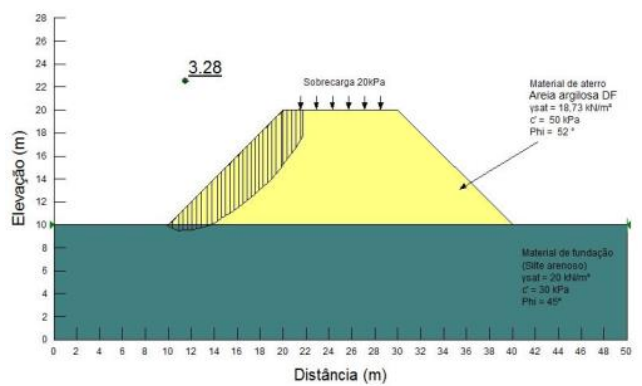

Figura 54 - Aterro de 10 metros com inclinação 1:1 e umidade ótima

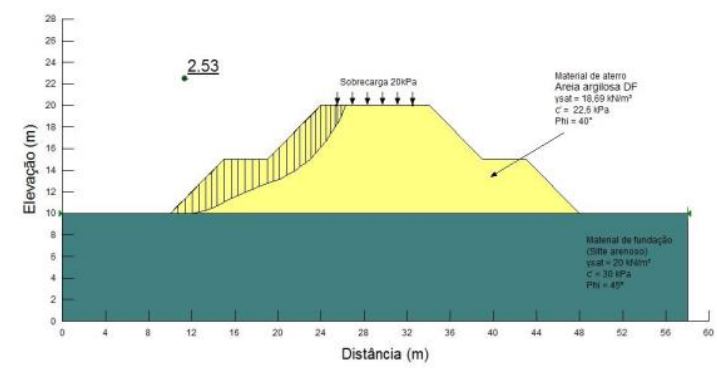

Figura 55 - Aterro de 10 metros $1: 1 \mathrm{c}$ / banqueta e umidade ótima $+2 \%$

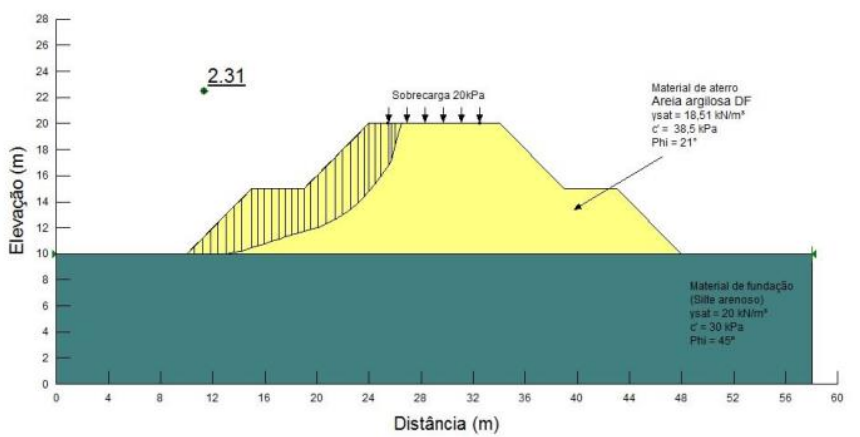

Figura 56 - Aterro de 10 metros $1: 1$ c/ banqueta e umidade ótima $+4 \%$ 


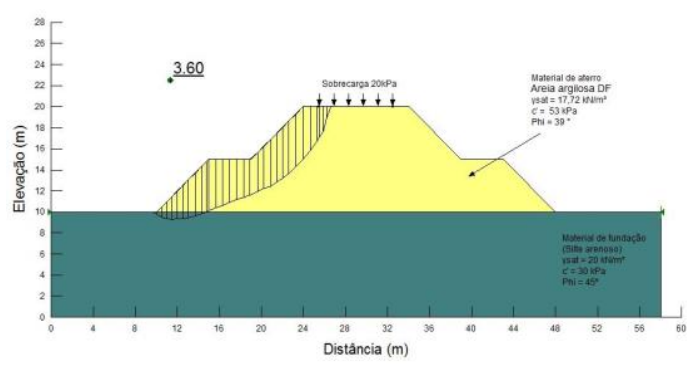

Figura 57 - Aterro de 10 metros 1:1 c/ banqueta e umidade ótima $-2 \%$

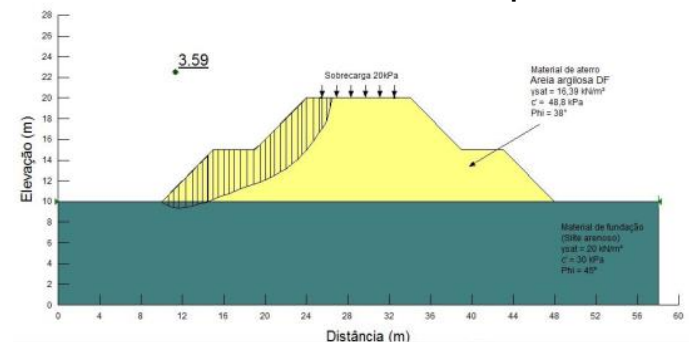

Figura 58 - Aterro de 10 metros 1:1 c/ banqueta e umidade ótima -4\%

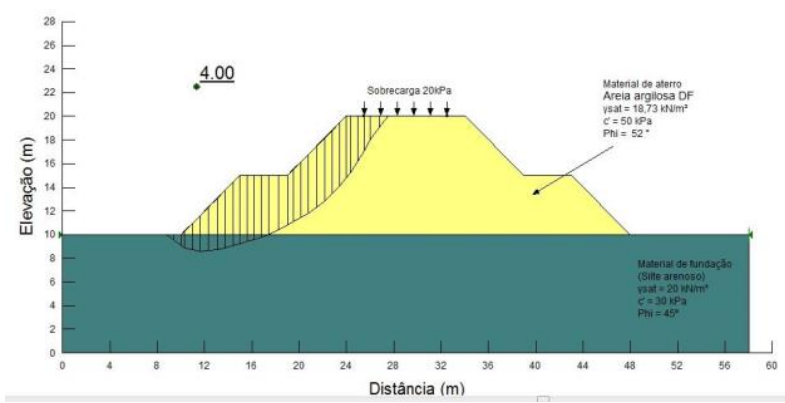

Figura 59 - Aterro de 10 metros $1: 1 \mathrm{c}$ / banqueta e umidade ótima

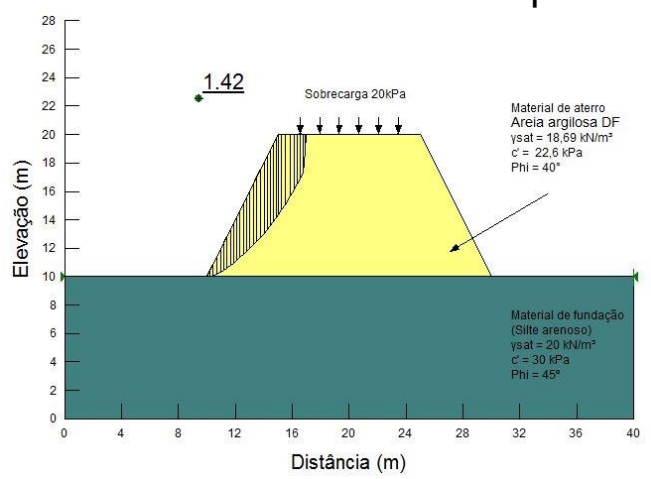

Figura 60 - Aterro de 10 metros com inclinação 1:2 e umidade ótima $+2 \%$

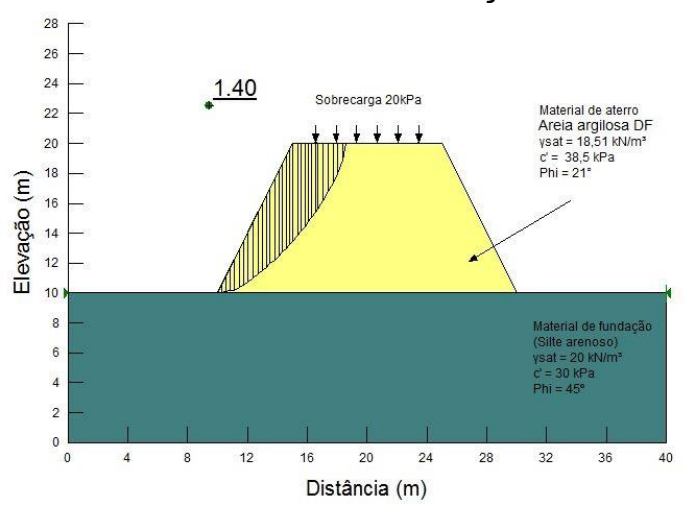

Figura 61 - Aterro de 10 metros com inclinação 1:2 e umidade ótima +4\% 


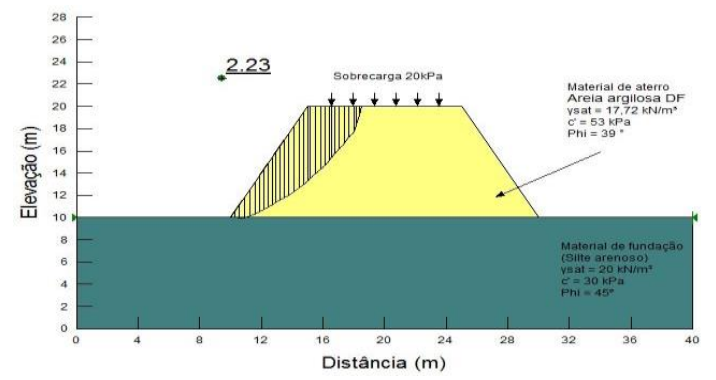

Figura 62 - Aterro de 10 metros com inclinação 1:2 e umidade ótima -2\%

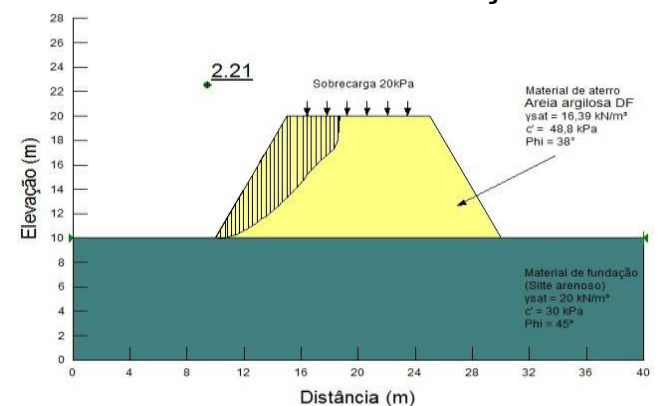

Figura 63 - Aterro de 10 metros com inclinação 1:2 e umidade ótima -4\%

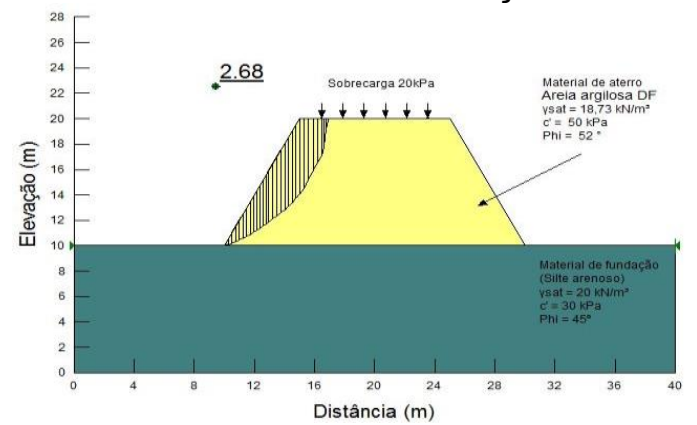

Figura 64 - Aterro de 10 metros com inclinação 1:2 e umidade ótima

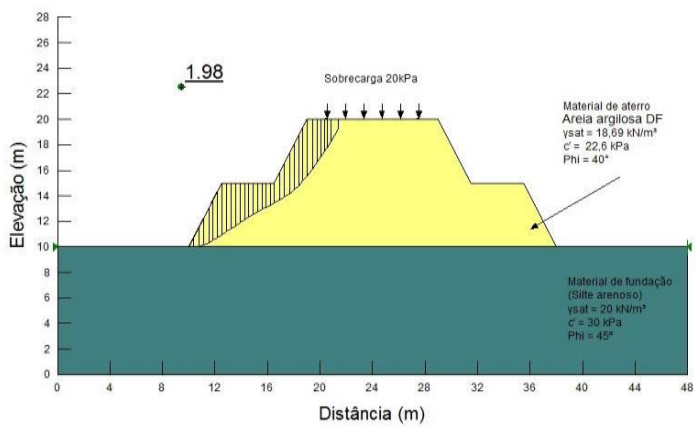

Figura 65 - Aterro de 10 metros $1: 2 \mathrm{c}$ banqueta e umidade ótima $+2 \%$

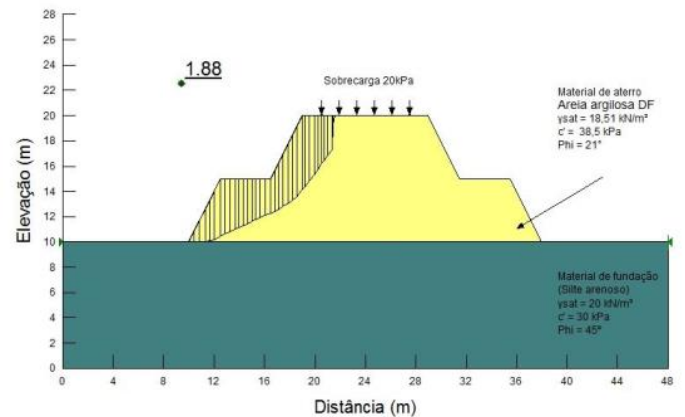

Figura 66 - Aterro de 10 metros $1: 2 \mathrm{c}$ banqueta e umidade ótima $+4 \%$ 


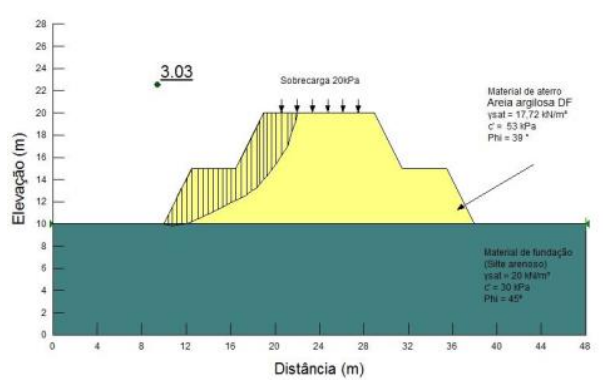

Figura 67 - Aterro de 10 metros 1:2 c/ banqueta e umidade ótima -2\%

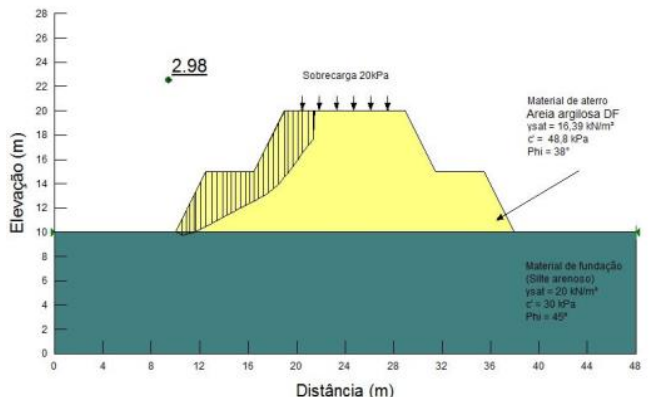

Figura 68 - Aterro de 10 metros $1: 2 \mathrm{c} /$ banqueta e umidade ótima $-4 \%$

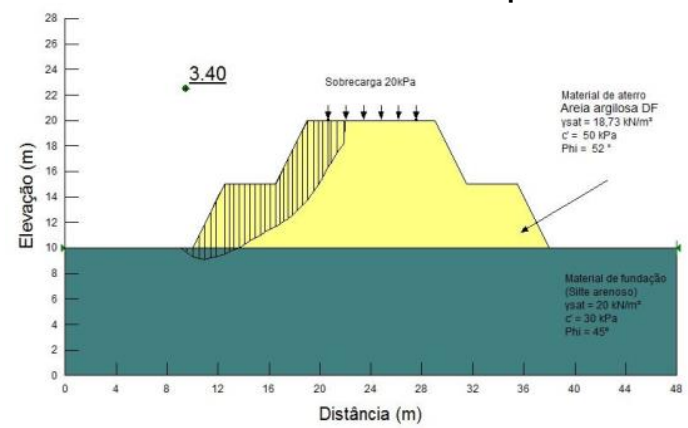

Figura 69 - Aterro de 10 metros 1:2 c/ banqueta e umidade ótima

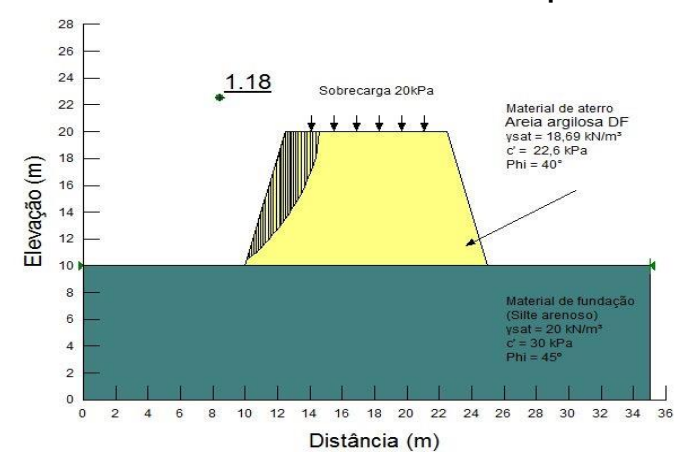

Figura 70 - Aterro de 10 metros com inclinação 1:4 e umidade ótima +2\%

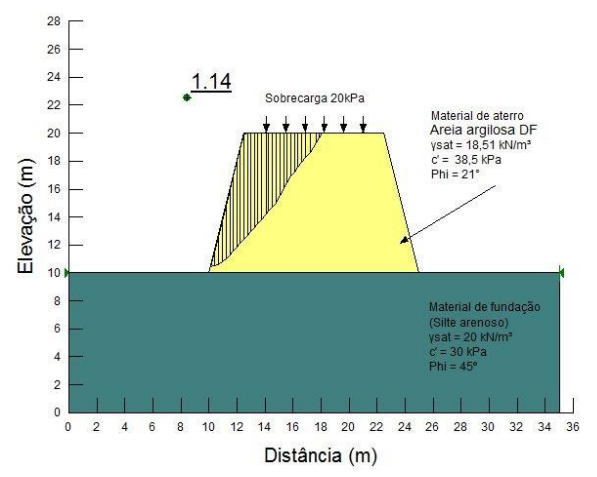

Figura 71 - Aterro de 10 metros com inclinação 1:4 e umidade ótima $+4 \%$ 


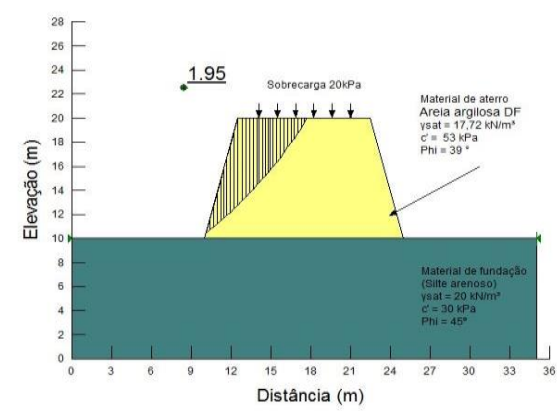

Figura 72 - Aterro de 10 metros com inclinação 1:4 e umidade ótima -2\%

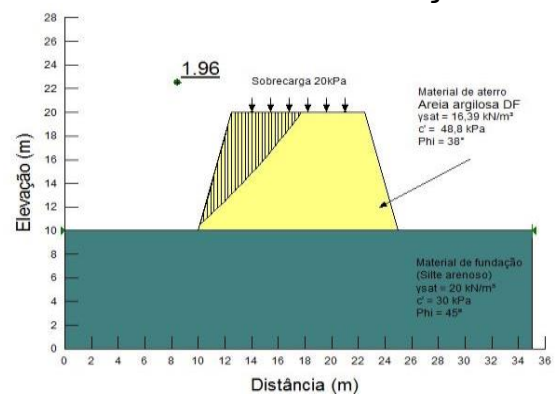

Figura 73 - Aterro de 10 metros com inclinação $1: 4$ e umidade ótima -4\%

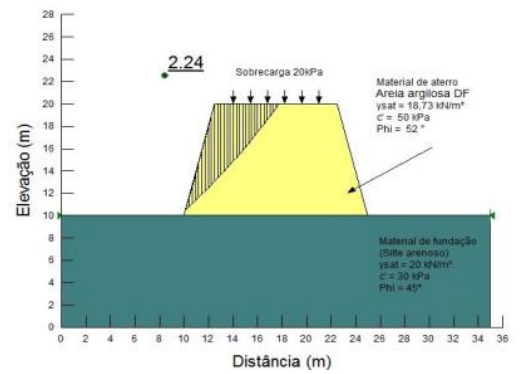

Figura 74 - Aterro de 10 metros com inclinação 1:4 e umidade ótima

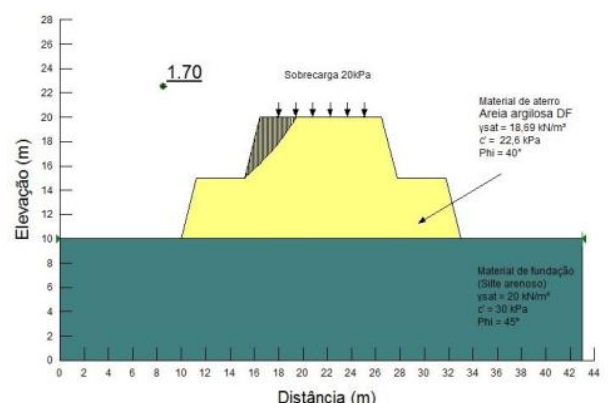

Figura 75 - Aterro de 10 metros $1: 4 \mathrm{c}$ / banqueta e umidade ótima $+2 \%$

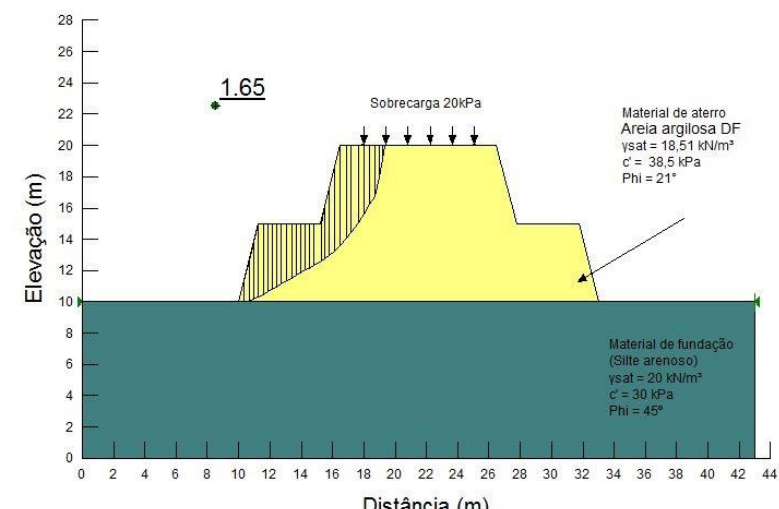

Figura 76 - Aterro de 10 metros $1: 4$ c/ banqueta e umidade ótima $+4 \%$ 


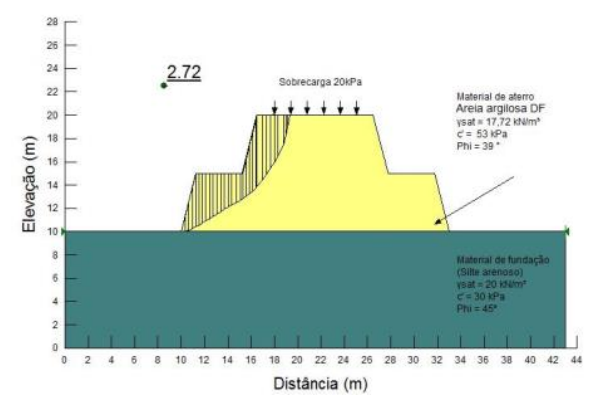

Figura 77 - Aterro de 10 metros $1: 4 \mathrm{c}$ / banqueta e umidade ótima -2\%

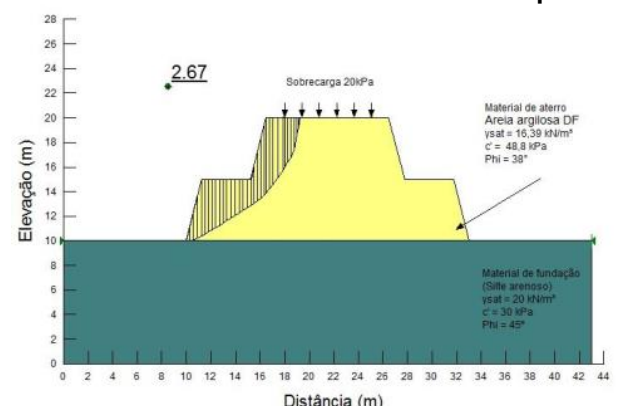

Figura 78 - Aterro de 10 metros 1:4 c/ banqueta e umidade ótima -4\%

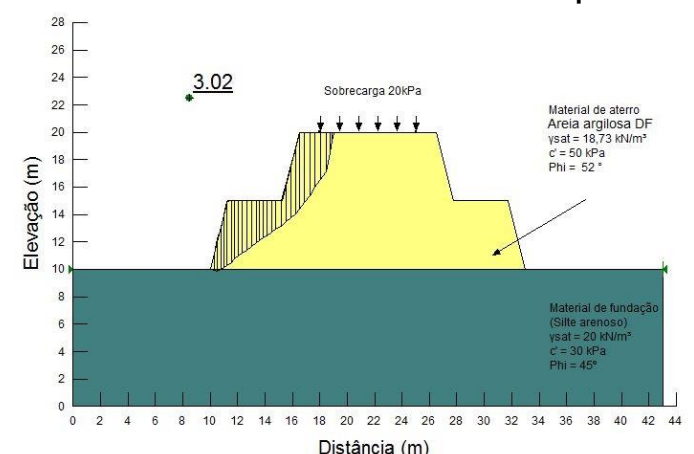

Figura 79 - Aterro de 10 metros 1:4 c/ banqueta e umidade ótima

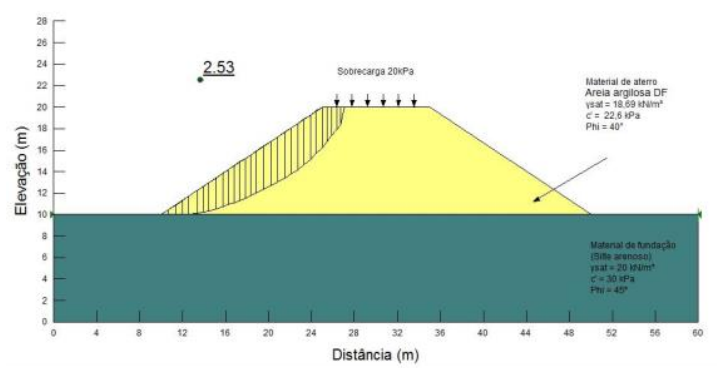

Figura 80 - Aterro de 10 metros com inclinação $3: 2$ e umidade ótima $+2 \%$

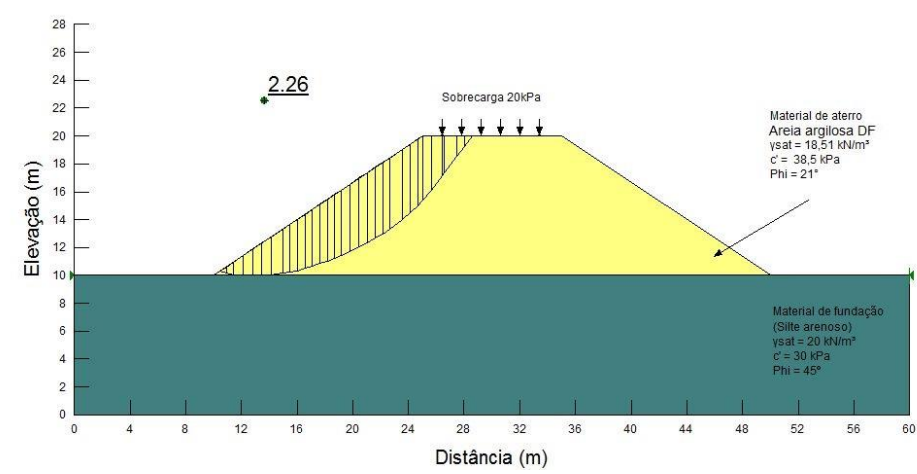

Figura 81 - Aterro de 10 metros com inclinação 3:2 e umidade ótima $+4 \%$ 


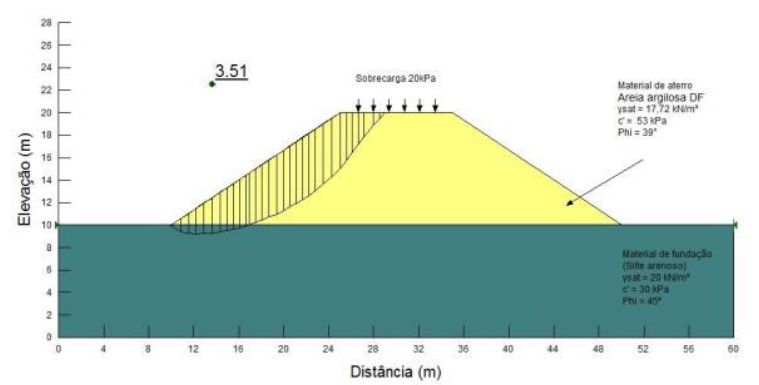

Figura 82 - Aterro de 10 metros com inclinação 3:2 e umidade ótima -2\%

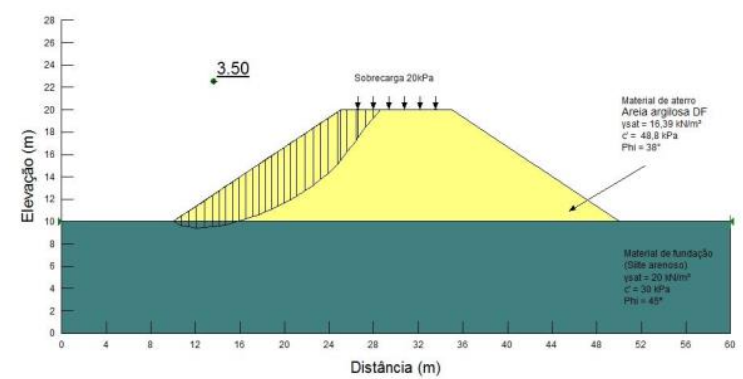

Figura 83 - Aterro de 10 metros com inclinação 3:2 e umidade ótima -4\%

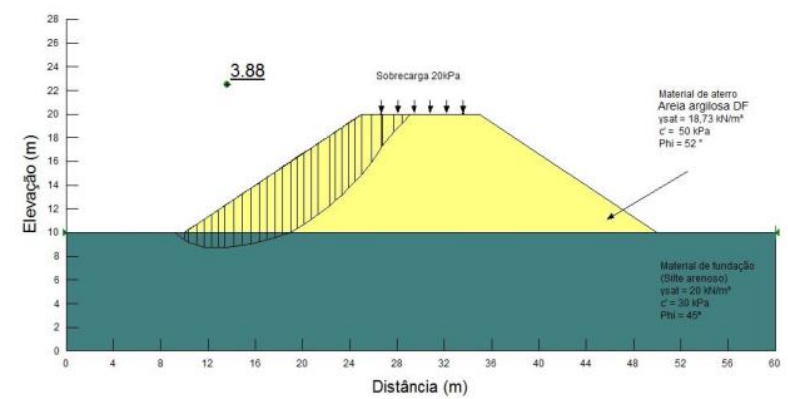

Figura 84 - Aterro de 10 metros com inclinação 3:2 e umidade ótima

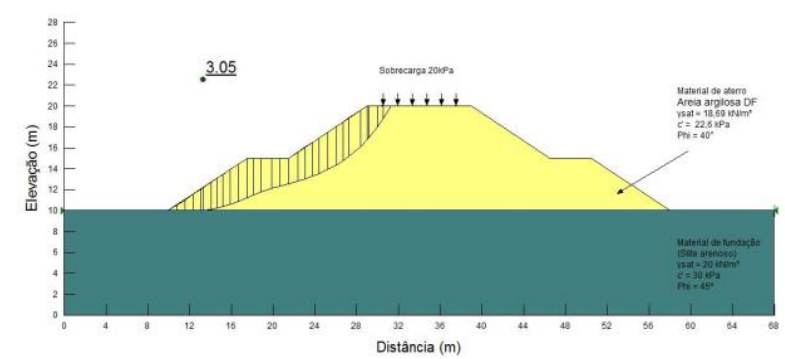

Figura 85 - Aterro de 10 metros 3:2 c/ banqueta e umidade ótima $+2 \%$

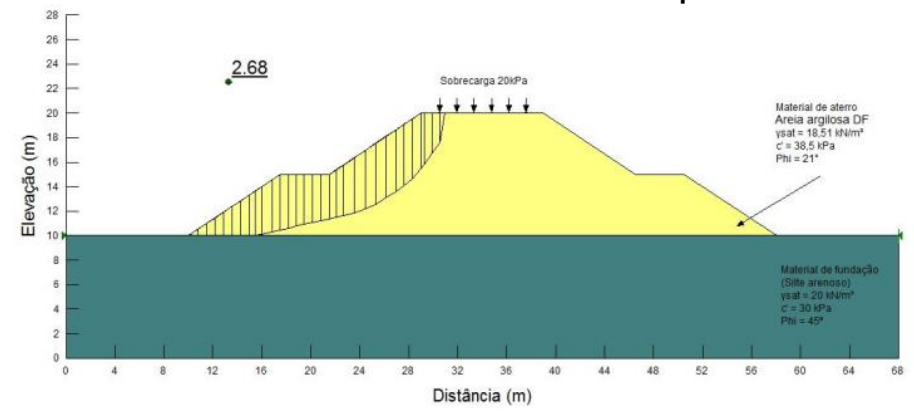

Figura 86 - Aterro de 10 metros 3:2 c/ banqueta e umidade ótima $+4 \%$ 


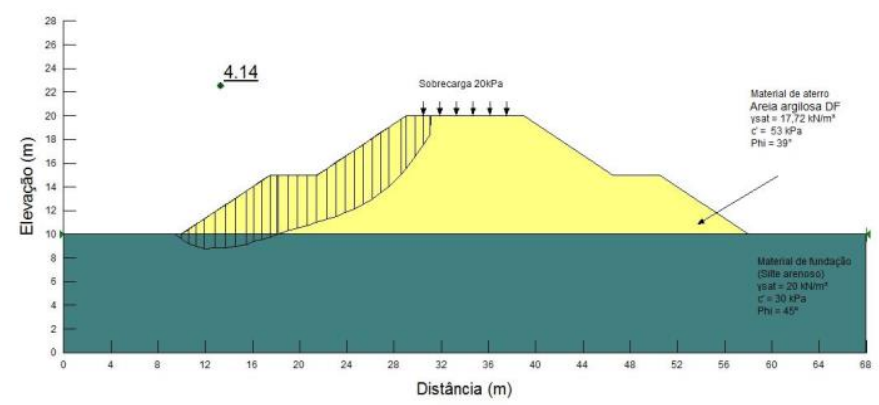

Figura 87 - Aterro de 10 metros $3: 2$ c/ banqueta e umidade ótima $-2 \%$

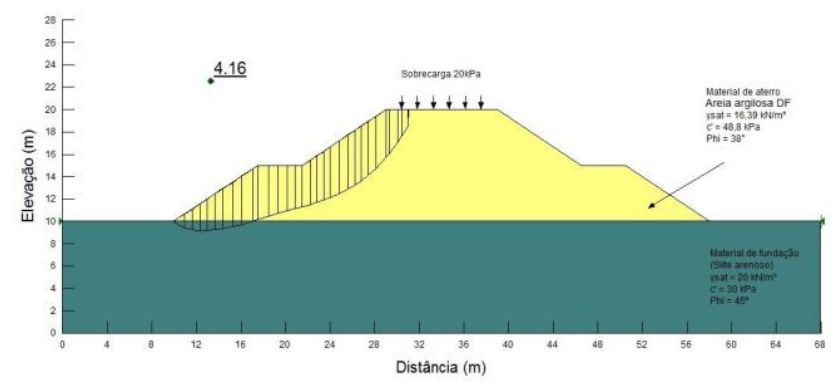

Figura 88 - Aterro de 10 metros 3:2 c/ banqueta e umidade ótima $-4 \%$

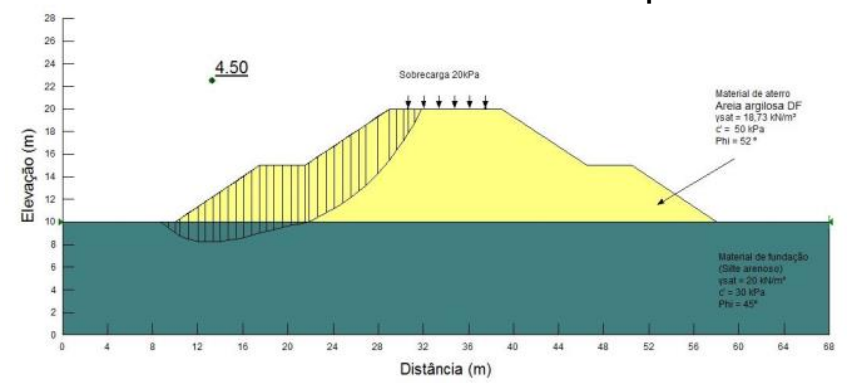

Figura 89 - Aterro de 10 metros 3:2 c/ banqueta e umidade ótima

A sobrecarga de $20 \mathrm{kPa}$ foi atribuída numa faixa de 7 metros, sendo atribuídos considerando uma pista simples com duas faixas de 3,5 metros. Observa-se que as faixas de ruptura não são circulares e tentam se aproximar da realidade por critérios do método de Morgentern \& Price.

\section{6 - Fatores de Segurança}

$\mathrm{Na}$ tabela 15, 16 e 17 se apresenta um resumo dos fatores de segurança obtidos para todas as seções típicas hipotéticas. A partir das tabelas de fatores de segurança, pode-se observar que o material possui uma qualidade muito boa, tendo em vista que independente da umidade apresenta fatores elevados que demonstram uma ótima resistência após passarem pelo processo de compactação. É importante ressaltar que esses fatores de segurança são obtidos para a condição da umidade natural sem saturação. Os fatores de segurança na condição saturada devem ser muito menores que os fatores de segurança apresentados.

Os fatores de segurança como visto anteriormente são considerados num intervalo de 1 até 2 sendo 1,5 considerado o máximo valor usual e um valor estável em relação a segurança atendendo elevando grau de risco econômico, de danos a vidas humanas e a danos materiais e do ambiente. Desse modo, os valores que ultrapassam de 2 serão avaliados apenas em relação a resistência do aterro em relação as suas configurações de seções hipotéticas. 
Tabela 15 - Fatores de Segurança de aterros com 5 metros de altura

\begin{tabular}{|l|c|c|c|c|}
\hline SEÇÃO DO ATERRO: & 5 metros 1:1 & 5 metros 1:2 & 5 metros 1:4 & 5 metros 3:2 \\
\hline Umidade ótima -4\% & 4,35 & 3,37 & 3,06 & 5,01 \\
\hline Umidade ótima -2\% & 4,3 & 3,37 & 3,02 & 4,96 \\
\hline Umidade ótima & 4,5 & 3,62 & 3,53 & 5,14 \\
\hline Umidade ótima +2\% & 2,75 & 2,03 & 1,73 & 3,42 \\
\hline Umidade ótima +4\% & 3,82 & 2,23 & 1,96 & 3,57 \\
\hline
\end{tabular}

Ao observar a tabela 12, pode-se notar que a umidade ótima retornou um fator de segurança maior em todas as seções, que no ramo seco os fatores se aproximam do ponto ótimo e que a situação de menor valor está no ramo úmido na seção com inclinação de 1:4. A inclinação 3:2 foi a seção que retornou os maiores valores sendo a única a ultrapassar o valor de 5 não só no ponto ótimo como também num déficit de $4 \%$ desta umidade, na prática comum da engenharia rodoviária os taludes de aterros são dimensionados com inclinação de 3:2 para garantir a estabilidade.

Apesar de ocorrer leves diferenças de uma seção para a outra, no Gráfico 1 pode-se concluir que o comportamento das seções, no que tange ao Fator de Segurança versus Umidade, apresentam-se de forma padrão com um valor máximo na umidade ótima e diminuindo quando se aproxima à umidade ótima $+2 \%$, a umidade ótima $+4 \%$ foi a situação de menor valor de FS de todas as seções hipotéticas.

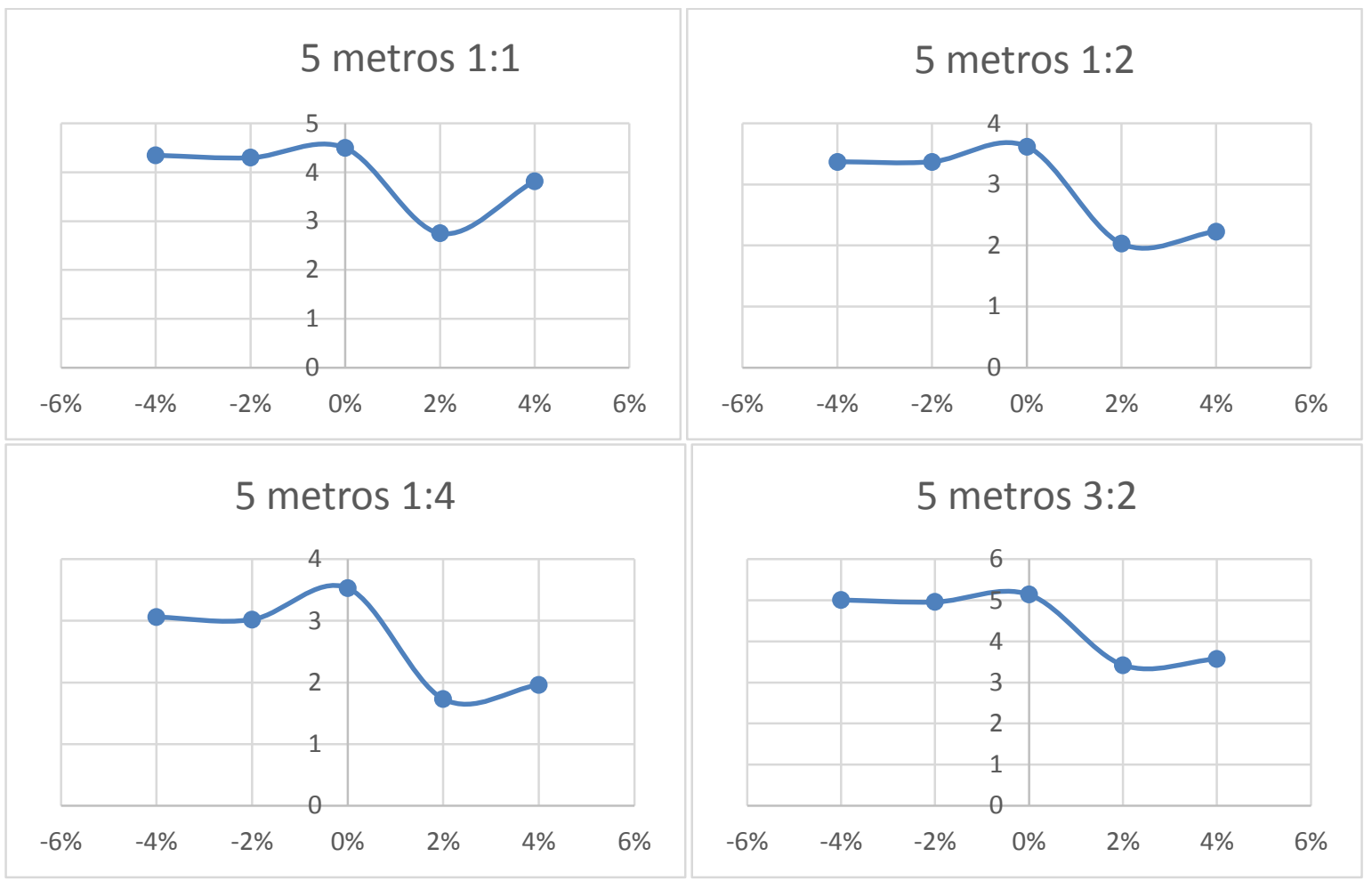

Figura 90 - Fatores de Segurança versus Umidade de Compactação 
Tabela 16 - Fatores de Segurança de aterros com 10 metros de altura

\begin{tabular}{|l|c|c|c|c|}
\hline SEÇÃO DO ATERRO: & 10 metros 1:1 & 10 metros 1:2 & 10 metros 1:4 & 10 metros 3:2 \\
\hline Umidade ótima -4\% & 2,90 & 2,21 & 1,96 & 3,5 \\
\hline Umidade ótima -2\% & 2,92 & 2,23 & 1,95 & 3,51 \\
\hline Umidade ótima & 3,28 & 2,68 & 2,24 & 3,88 \\
\hline Umidade ótima +2\% & 2,00 & 1,42 & 1,18 & 2,53 \\
\hline Umidade ótima +4\% & 1,86 & 1,40 & 1,14 & 2,26 \\
\hline
\end{tabular}

O comportamento dos aterros com 10 metros de altura também aponta a inclinação 3:2 como a opção de maior valor de fator de segurança, e segue o padrão dos aterros de 5 metros tendo a inclinação 1:4 como a situação que retorna os fatores mais baixos, apresenta a umidade ótima $+4 \%$ com os menores Fatores de Segurança. Os valores da segurança decaem consideravelmente nos aterros de 10 metros em relação aos de 5 metros podendo-se concluir que a altura do aterro também contribui para a diminuição da estabilidade. E é por este motivo que tanto num corte, quanto num aterro em que as dimensões são bastante elevadas, devem-se utilizar banquetas tanto para estabilizar o sistema, quanto para diminuir o empuxo de terra na base. $\mathrm{E}$ por isso foi analisado também as mesmas inclinações de 10 metros com banquetas de quatro metros de largura para poder ser estudado a diferença das duas situações.

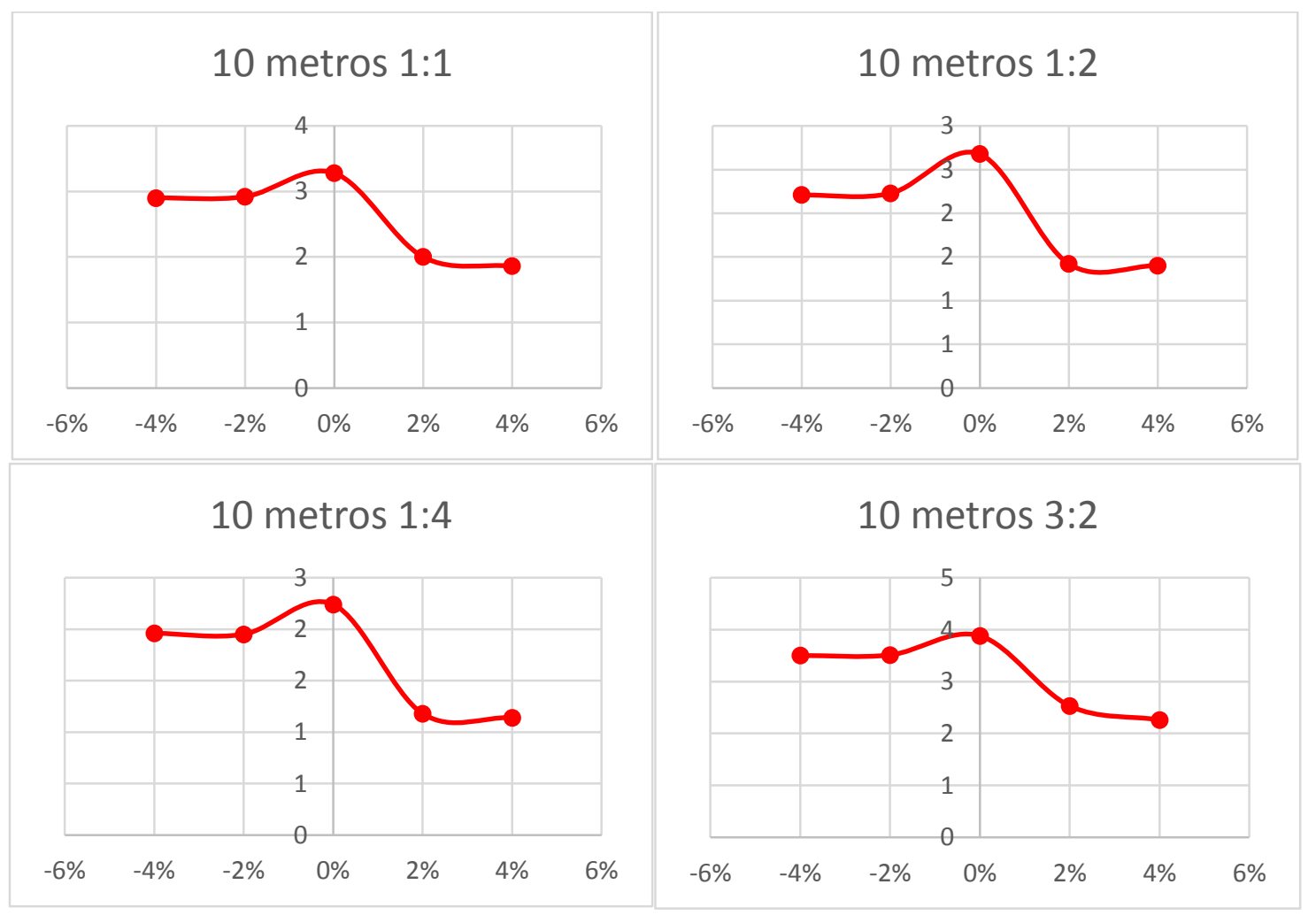

Figura 91 - Fatores de Segurança versus Umidade de Compactação

A Figura 91 apresenta a mesma forma da Figura 90. Todavia a queda do ponto ótimo para o ponto ótimo $+2 \%$ é mais brusca, e o decréscimo continua no ponto $+4 \%$ onde, avaliando a resistência, seria mais propicio a ocorrência de uma ruptura. 
Tabela 17- Fatores de Segurança de aterros com 10 metros de altura com banqueta

\begin{tabular}{|l|c|c|c|c|}
\hline SEÇÃO DO ATERRO: & $\begin{array}{l}\text { 10 metros 1:1 } \\
\text { c/ banqueta }\end{array}$ & $\begin{array}{l}\mathbf{1 0} \text { metros 1:2 c/ } \\
\text { banqueta }\end{array}$ & $\begin{array}{l}\mathbf{1 0} \text { metros 1:4 c/ } \\
\text { banqueta }\end{array}$ & $\begin{array}{l}\mathbf{1 0} \text { metros 3:2 c/ } \\
\text { banqueta }\end{array}$ \\
\hline Umidade ótima -4\% & 3,59 & 2,98 & 2,67 & 4,16 \\
\hline Umidade ótima -2\% & 3,60 & 3,03 & 2,72 & 4,14 \\
\hline Umidade ótima & 4,00 & 3,40 & 3,02 & 4,50 \\
\hline Umidade ótima +2\% & 2,53 & 1,98 & 1,70 & 3,05 \\
\hline Umidade ótima +4\% & 2,31 & 1,88 & 1,65 & 2,68 \\
\hline
\end{tabular}

Como foi dito anteriormente, as banquetas funcionam a favor da segurança. Nota-se um aumento considerável da estabilidade tendendo aos valores do aterro de 5 metros. A inclinação 1:4 novamente encontra-se na configuração de menor resistência. Todavia, desta vez está bem parelha à inclinação 1:2. A umidade ótima $+4 \%$ persiste em ser a circunstancia de menores valores e a Figura 92 porta-se da mesma maneira que os outros obedecendo o padrão desde o início.

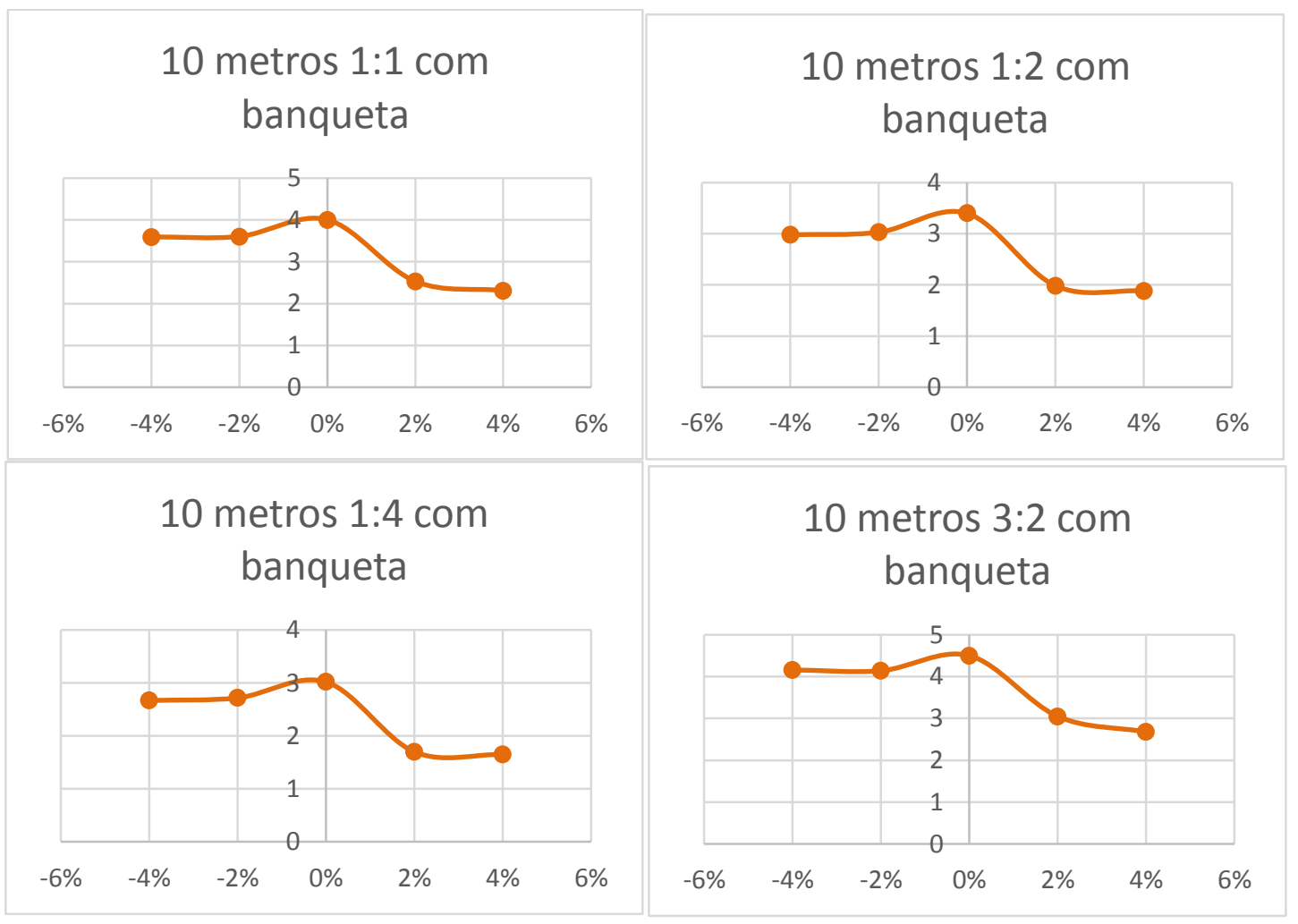

Figura 92 - Fatores de Segurança versus Umidade de Compactação

No geral, pode-se observar que os aterros compactados no ramo seco apresentam os maiores valores de fator de segurança, desconsiderando a umidade ótima, sendo coerente com a campanha experimental que apresenta o ramo seco com os maiores interceptos coesivos e com ângulos de atritos satisfatórios em relação às outras umidades e a umidade ótima. 


\section{5 - CONCLUSÕES}

O intuito do trabalho era avaliar o comportamento do solo do Distrito Federal na conformação de aterros rodoviários em diversas umidades para saber qual situação seria mais adequada quando não fosse possível manter o controle tecnológico e o controle de qualidade do material quando este estiver exposto às intempéries.

Neste contexto, ficam nítidos quais são as configurações mais aceitáveis tendo em vista que, apesar de diversas inclinações e alturas, as curvas de Fator de Segurança $x$ Umidade comportam-se de forma padronizada para todas as hipóteses.

Este comportamento padrão facilita na identificação das piores e melhores situações e torna a informação de certa forma mais confiável. Nos gráficos pode-se observar que a inclinação que retorna os menores valores de fator de segurança em qualquer situação é a 1:4, e que a configuração com o menor valor encontrado, globalmente falando, é o aterro de 10 metros com inclinação $1: 4$ e umidade ótima $+4 \%$ retornando um valor de Fator de Segurança de 1,14. A configuração que retornou o maior fator é a do aterro de 5 metros com inclinação 3:2 e que expõe o maior valor de FS na umidade ótima com o valor de 5,14 .

$O$ aterro de 10 metros mesmo com banqueta não apresenta nenhum valor acima de 5 , sendo mais vantajoso os aterros de 5 metros. Se não for possível utilizarse no projeto um talude de cinco metros de altura com inclinação de 3:2 na umidade ótima, aconselha-se utilizar o ramo seco da umidade não precisando se importar tanto se é ponto ótimo $-2 \%$ ou $-4 \%$ pois estas duas umidades apresentaram fatores de segurança semelhantes.

Para os valores previstos em norma, tem-se o aterro de 10 metros com inclinação de 1:4 que fornece na umidade ótima $+2 \%$ e $+4 \%$ condições de aterros que só podem ser utilizados quando os riscos de danos à vida humana, ao ambiente e ao material forem desprezíveis e que um eventual colapso não acarretará e qualquer tipo de catástrofe.

Na sequência, os aterros de 10 metros com inclinação 1:2 e umidade ótima $+2 \%$ e $+4 \%$ já possuem capacidade de serem construídos para suportarem a responsabilidade de um nível médio para elevado de risco de ocorrência de danos e de grandes catástrofes que poderiam ocorrer a depender do grau de importância da rodovia, do fluxo diário e dos tipos de veículos que trafegam nela.

Os aterros de 5 metros com inclinação $1: 4$ e umidade também de $+2 \%$ e $+4 \%$ da ótima apresentam valores já mais que satisfatórios e que não são nem definidos pela norma ABNT NBR 11682/09.

Pode-se observar também que em todas as seções os valores apresentaram resistências altas dos matérias e que a segurança está relacionada não só apenas com a importância e o risco envolvido do aterro, mas também com a durabilidade e funcionalidade, tendo em vista que algumas rodovias no Brasil apresentam falhas na estrutura sem ter ultrapassado o período para qual foram projetadas e que os taludes podem sofrer rupturas geradas pelas deficiências de projetos e especificação de compactação, além da falta de manutenção que é recorrente no país.

As banquetas, com o objetivo de aumentar o fator de segurança e permitir a implantação de drenagem superficial dividindo a vazão em cada trecho do sistema drenante, diminuem o ângulo médio do talude. A altura do talude entre cada banqueta e sua largura deve ser calculada visando atender à estabilidade geral. A altura do talude entre as banquetas não deve exceder 15 metros. As banquetas são importantes 
também para a redução da energia cinética de blocos rochosos em queda e com isso mais uma vez se comportam a favor da segurança.

É importante ressaltar que o trabalho realizado é de caráter acadêmico e não conclusivo, os fatores de segurança em todos os casos se apresentam elevados pelo fato de trabalhar com parâmetros mecânicos obtidos a partir de ensaios de cisalhamento na condição natural sem saturação. Quando o material seja saturado em períodos de chuvas intensas com certeza os fatores de segurança vão ser muito menores.

Como sugestão para pesquisas futuras, devem ser realizados ensaios de cisalhamento direto em amostras compactadas com os mesmos teores desta pesquisa e submeter ao processo de ruptura no equipamento de cisalhamento direto na condição saturada, para representar de uma melhor forma a condição mais crítica do aterro rodoviário.

\section{6 - REFERÊNCIAS}

ABNT. (1984-a). NBR 6508. Grãos de solo que passam na peneira 4,8 mm Determinação da massa específica. ABNT, Rio de Janeiro, RJ.

ABNT. (1984-c). NBR 6459. Solo - Determinação do limite de liquidez. ABNT, Rio de Janeiro, RJ.

ABNT. (1984-d). NBR 7180. Solo - Determinação do limite de plasticidade. ABNT, Rio de Janeiro, RJ.

ABNT. (1986-a). NBR 6457. Amostras de solo - preparação para ensaios de compactação e ensaios de caracterização. ABNT, São Paulo, SP.

ABNT. (1986-b). NBR 7182. Solo - Ensaio de compactação. ABNT, Rio de Janeiro, RJ.

ABNT. (1988). NBR 2887. Solo - Determinação da massa específica natural. ABNT, Rio de Janeiro, RJ.

Aguilar, L.A. (2010). Contribuições para a análise do comportamento mecânico de solos compactados para uso em barragens. Dissertação de mestrado, Faculdade de Tecnologia, Departamento de Engenharia Civil e Ambiental, Universidade de Brasília, Brasília, DF.

Araki, M.S. (1997). Aspectos relativos às propriedades dos solos porosos colapsíveis do Distrito Federal. Dissertação de Mestrado, Faculdade de tecnologia, Departamento de Engenharia Civil e Ambiental, Universidade de Brasília, Brasília, DF, $121 p$.

Assis, A.P. et al (2003). Apostila do curso de Barragens. UnB, Brasília, DF, 170p.

Balmaceda, A.R. (1991). Suelos compactados - Un estudio teórico y experimental. Tesis doctoral. Universidad Politécnica de Cataluña, Barcelona

Bernucci, L. L. B. Considerações sobre o dimensionamento de pavimentos utilizando solos lateríticos para rodovias de baixo volume de tráfego. 1995. 237 f. Tese (Doutorado em Engenharia Civil) - Escola Politécnica, Universidade de São Paulo, São Paulo, 1995.

Buriticá, J.A. (2013). Análise de Comportamento de Barragens Construídas com Núcleos Argilosos Compactados no Ramo Super Úmido. Dissertação de Mestrado, Publicação G.DM-232/13, Departamento de Engenharia Civil e Ambiental, Universidade de Brasília, Brasília, DF, 124 p. 
Camapum de Carvalho, J. \& Leroueil, S. (2000). Modelo de Normalização da Curva Característica. 32a Reunião Anual de Pavimentação, Brasília.

Cardoso, F.B.F (1995). Análise química, mineralógica e micromorfológica de solos tropicais colapsíveis e o estudo da dinâmica do colapso. Dissertação de mestrado G.DM-026A/95. Mestrado em Geotecnia, UnB.

Cetin, H. et al. (2000). Settlement and slaking Problems in the world's fourth largest rock-fill dam, the Ataturk Dam in Turkey. Engineering geology, 56, pp. 225-242

Cetin, H. et al (2007). Soil structure changes during compaction of a cohesive soil. Engineering geology, 92, pp. 38-48

Cui, Y.J. \& Delage, P. (1993). On the elastoplastic behavior on unsaturated soils. Unsaturated soils, Proceedings of Ses. Sponsored by Subcommittee on Unsaturated Soils. ASCE

Cui, Y.J.; Delage, P.; Audiguier, M.; Michael, D.H. (1996). Microstructure of a compacted silt, Canadian Geotechnical Journal, 33, pp.150-158.

Cui, Y.J.; Loiseau, C.; Delage, P. (2002). Microstructure changes of a confined swellings oil due to the suction controlled hydration. International conference on unsaturated soils, 3, Unsat, Recife, Vol II, pp 593-598.

Das, B.M.(1990). Fundamentos de engenharia geotécnica. Tradução da 6. Ed americana. São Paulo: Thomson Learning, 562p

Das, B.M. (2007). Fundamentos de engenharia geotécnica; tradução All Tasks; revisão técnica Pérsio Leister de Almeida Barros. - São Paulo: Thomson Learning.

Delgado, A. K. C. (2007). Estudo do Comportamento Mecânico de solos tropicais característicos do Distrito Federal para uso na Pavimentação Rodoviária. Tese de Doutorado, G.TD-044/07, Departamento de Engenharia Civil e Ambiental, Universidade de Brasília, Brasília, DF, 391p.

Fernandes, M. (1994). Mecânica dos Solos - I Volume (reimpressão de Julho 2003). Faculdade de Engenharia da Universidade do Porto.

Fredlund, D.G. (1997). An introduction to unsaturated soil mechanics. American Society of Civil Engineers, Geotechnical Engineering Division, GeoLogan Conference, Special Geotechnical Publication No. 86 entitled Unsaturated Soils Engineering Pratice, Logan, Utah.

Geo-slope international. (2008). Stability modeling with SLOPEN, an engineering methodology. Ed 3. $367 \mathrm{p}$

Guimarães, R.C., Camapum de Carvalho, J., Farias, M. M. (1997). Contribuição ao estudo da utilização de solos finos em pavimentação. $1^{\circ}$ Simpósio Internacional de Pavimentação de Rodovias de Baixo Volume de Tráfego, ABPv, Rio de Janeiro, RJ.

Holtz, R.D. \& Kovacs, W.D. (1981).An introduction to geotechnical engineering. Prentice-Hall, Eagle wood Cliffs.

Jafari, M.K. \& Shafiee, A. (2004). Mechanical behavior of compacted composite clays. Canadian Geotechnical Journal, 41, pp. 1152-1167.

JUCÁ, F. T. J. (1990). Comportamiento de los suelos parcialmente saturados bajo succión controlada. Universidad Politécnica de Madrid. Madrid. Tesis doctoral.

Lambe, T.W. \& Whitman, R.V. (1979).Mecánica de suelos, Limusa, México, México, $582 \mathrm{p}$

Lambe, T.W. (1958) “ The engineering behavior of compacted clay."J. Soil Mech. Found. Eng, ASCE, 84(8), 1-35.

Lambe, T.W. (1960). A mechanistic picture of shear strength in clay. Proc. ASCE Conf. on Shear Strength of Cohesive Soils, Boulder, University of Colorado, pp. 555-580. 
Martínez, G.S.S. (2003). Estudo do Comportamento Mecânico de Solos Lateríticos da Formação Barreiras. Tese de Doutorado. Universidade Federal do Rio Grande do Sul, Porto Alegre.

Massad, F. (2010). Obras de terra. Curso básico de Geotecnia. 2.ed. Oficina de textos de São Paulo. São Paulo. SP. 215p

Mendonça, M. B. (1990). Comportamento de Solos Colapsíveis da Região de Bom Jesus da Lapa - Dissertação de Mestrado, COPPE/UFRJ, Rio de Janeiro, RJ.

Mitchell, J.K. (1956). The fabric of natural clay sand its relation to engineering properties. Proceedings of the Highway Research Board, Vol. 35, pp. 693-713.

Mitchell, J.K. (1976). Fundamentals of soil behavior, University of California, Berkeley, $422 p$

Mitchel, J.K. (1993). Fundamentals of Soil Behavior, John Wiley \& Sons, New York.

Morgenstern, N. R. and Price, V. E. (1965), "The Analysis of the Stability of General Slip Surfaces", Geotechnique.

Morgenstern N. (1979). Properties of compacted soils. Proc. 6th Pan-Am. Conf. on Soil Mech. Contribution to panel discussion Session IV, Lima, Peru: ISSMGE, pp. 349354.

Motta, L.M.G.; Medina, J. (2006) Investigação e desenvolvimento em Mecânica dos Pavimentos na COPPE - Brasil. Revista Engenharia Civil, N. 26. COPPE/UFRJ: Portugal.

Nogami, J. S., Villibor, D. F., Beligni, M. e Cincerre, J. R. (2000). "Pavimentos com Solos Lateríticos e gestão de manutenção de Vias Urbanas". São Paulo.

Nuñez, E. (1975). Suelos Colapsibles y preconsolidados por dessecacion. In: v congresso pan americano de mecanica de suelos y ingenieria de fundaciones, Buenos Aires.

Pinto, C.S. (2000) Curso Básico de Mecânica dos solos. 2. Ed. Oficina de textos, São Paulo, SP,355p

Proctor, R.R. (1933). Fundamental principles of soil compaction. Engineering News Record, pp. 241-248, 286-289, 372-376.

Queiroz de Carvalho, J.B. (1987). Análise da Microestrutura de Solos Lateríticos do Brasil. 22를 Reunião Anual de Pavimentação, Maceió.

Queiroz de carvalho, J. B.; Simmons, J. V. (1997). Mineralogy and microstructure. In: BLIGHT, G.E, Mechanical of residual soils. Rotterdam, Brookfield: Ed. Balkema.

Reschettl, P. R. Jr. (2008). Avaliação do comportamento mecânico de um solo arenoso fino laterítico reforçado com fibras para uso em pavimentos. Dissertação (Mestrado). Escola de Engenharia de São Carlos, Universidade de São Paulo. São Carlos.

Ribeiro, S.P. (2008). Terraplenagem. Metodologia e técnicas de compactação. Dissertação de mestrado, Faculdade de Engenharia, Departamento de engenharia civil, Universidade do Porto.

Ricardo, H.S \& Catalani, R. (2007). Manual prático de escavação - Terraplenagem e escavação de rocha. Pini, São Paulo, Brasil, 3 ed., 656p

Romo, M. P.; Mendonza, M. L.; Yanes, M. (1979). Influence of microstructure on the suction developed by a compacted soil. In: Congresso panamericano de mecanica de suelos e ingenieria de cimentaciones. 6., Lima, Proceedings.

Santos, G. \& Martinez, S. (2003). Estudo do comportamento mecânico de solos lateríticos da formação Barreiras. Tese de doutorado, Escola de engenharia, Universidade Federal do Rio Grande do Sul, Porto Alegre, RS. 
Santos, P.S. (1975). Tecnologia de Argilas aplicada às argilas Brasileiras. Vol. 1Fundamentos. Ed. Edgar Blucher, Ed. Da universidade de São Paulo, São Paulo, $340 \mathrm{p}$

Santos, E. F. (2006). Estudo comparativo de diferentes sistemas de classificações geotécnicas aplicadas a solos tropicais. Escola de Engenharia de São Carlos, Universidade de são Paulo, São Carlos. Dissertação de Mestrado.

Seed, H.B. \& Chan, C.K. (1959). Structure and strength characteristics of compacted clays. Journal of the soil mechanics and foundation division, ASCE, 85, pp. 87-12 